\title{
Market Trends in the U.S. ESCO Industry: Results from the NAESCO Database Project
}

\author{
Principal Authors \\ Charles A. Goldman, Julie G. Osborn, and Nicole C. Hopper, LBNL \\ Terry E. Singer, NAESCO \\ Energy Analysis Department \\ Environmental Energy Technologies Division \\ Ernest Orlando Lawrence Berkeley National Laboratory \\ University of California \\ Berkeley, CA 94720
}

http://eetd.lbl.gov/ea/EMS/EMS_pubs.html

May 2002

The work described in this paper was funded by the Assistant Secretary of Energy Efficiency and Renewable Energy, Office of Power Technologies and Rebuild America Program under the Office of Energy Efficiency and Renewable Energy of the U.S. Department of Energy under Contract No. DE-AC03-76SF00098. 


\begin{abstract}
The U.S. Energy Services Company (ESCO) industry is often cited as the most successful model for the private sector delivery of energy-efficiency services. This study documents actual performance of the ESCO industry in order to provide policymakers and investors with objective information and customers with a resource for benchmarking proposed projects relative to industry performance. We have assembled a database of nearly 1500 case studies of energyefficiency projects - the most comprehensive data set of the U.S. ESCO industry available. These projects include $\$ 2.55 \mathrm{~B}$ of work completed by 51 ESCOs and span much of the history of this industry.

We estimate that the ESCO industry completed \$1.8-2.1B of projects in 2000. The industry has grown rapidly over the last decade with revenues increasing at a $24 \%$ annualized rate. We summarize and compare project characteristics and costs and analyze energy savings, including the relationship between predicted and actual savings. ESCOs typically invested about $\$ 2.30 / \mathrm{ft}^{2}$ per project in various energy efficiency improvements, although there is large variation in project costs within and across market segments. We find that lighting-only projects report median electricity savings of $47 \%$ of targeted equipment consumption; the median for lighting-\&-nonlighting projects is $23 \%$ of the total electric bill baseline. We examine project economics, including project net benefits, benefit/cost ratio and simple payback time. Median simple payback time is seven years for institutional sector projects and three years in the private sector. We estimate direct economic benefits of $\$ 1.62$ billion for the 1080 projects in our database with both cost and savings data. The median benefit/cost ratio is 2.1 for 309 private sector projects and 1.6 for 771 institutional sector projects. We discuss the role of policies and programs adopted by state/federal legislatures and agencies that have played an important role in stimulating ESCO activity in various markets. Finally, we estimate the overall size and growth of the energy-efficiency services industry over the last ten years based on a survey of 63 ESCOs.
\end{abstract}




\section{Acknowledgements}

We thank Dan Sze and Larry Mansueti at U.S. DOE, Ron Shelton at Oak Ridge National Laboratory (ORNL), and Nina Lockhart at the National Association of Energy Services Companies (NAESCO) for their support of this project.

We would like to thank the following individuals and organizations that contributed valuable information on energy efficiency projects and ESCO industry activity: Dave Birr at Synchronous Energy Solutions, Inc, Don Gilligan at Predicate LLC, Dave Dayton at Select Energy, Steve Morgan at Citizens Conservation Services, Patti Donahue at Donahue \& Associates, Brad Gustafson and Tatiana Strajnic at the U.S. Department of Energy, Ron Dombrowski at Illinois Department of Commerce and Community Affairs, Tom Barone, John Ahearn, and Brian Henderson at New York State Energy Research and Development Authority (NYSERDA), Tom Krupiarz at State of Michigan Energy Office, Linda Smith at the Energy Service Coalition of America, Kitty Cammack at the Kentucky Department of Education, Tim Howe at the Rhode Island State Energy Office, and NAESCO members. LBNL staff involved in various aspects of initial data collection include Abby Shaw-Krauss, Patty Juergens, Meredith Fowlie, Kaoru Kawamoto, and Steve Pickle.

We are particularly grateful to Don Gilligan and Dave Birr for their thoughtful comments and discussions on this report. 


\section{Table of Contents}

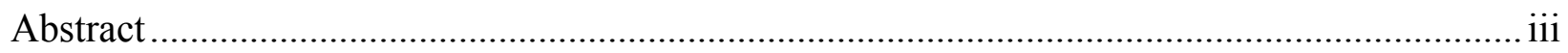

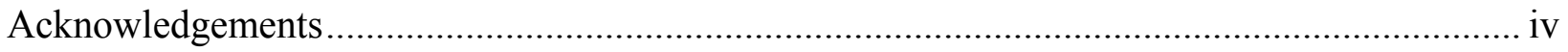

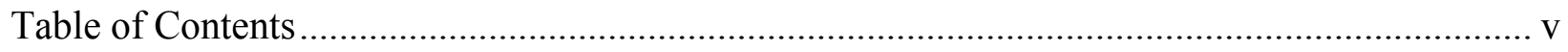

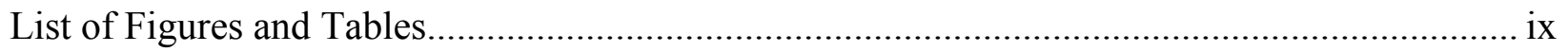

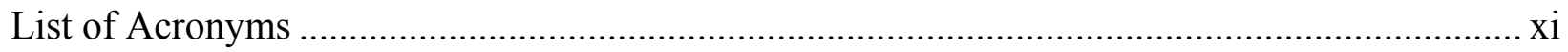

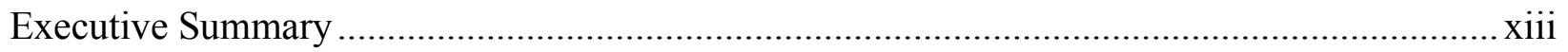

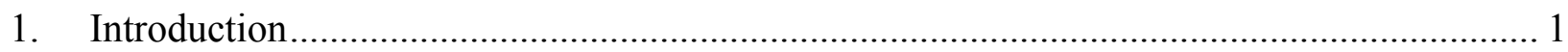

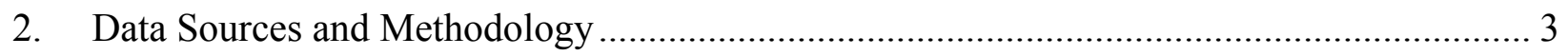

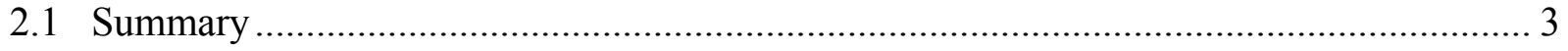

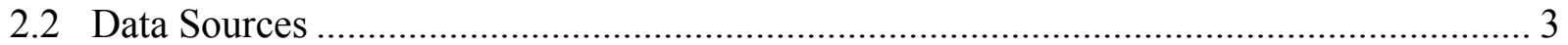

2.3 Data Quality and Confidentiality .............................................................................. 4

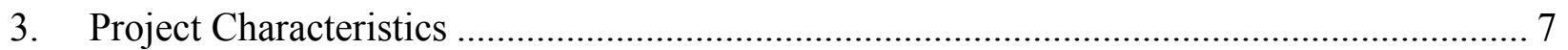

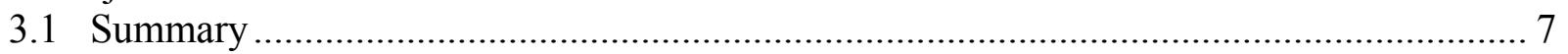

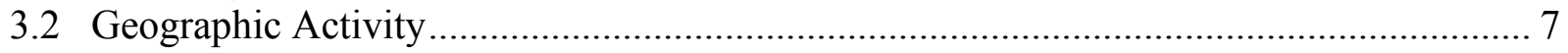

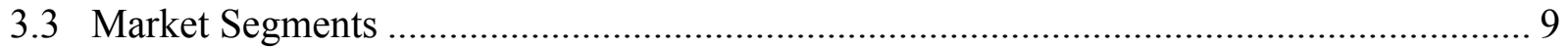

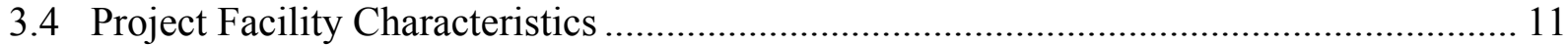

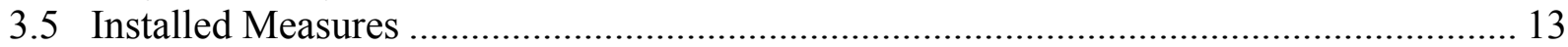

3.5.1 Penetration Rates for Various Types of Energy Conservation Measures (ECMs) ... 13

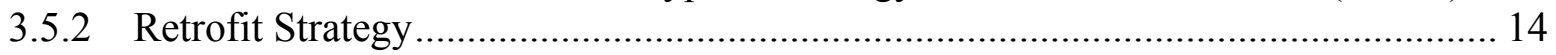

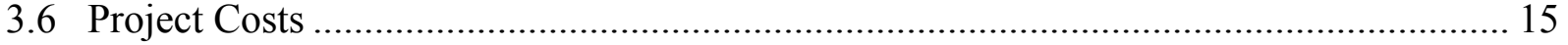

3.6.1 Project Costs by Market Segment...................................................................... 16

3.6.2 Factors That Contribute to Variation in Project Costs............................................ 17

3.7 Types of Contract Agreement and Term ................................................................. 19

3.7.1 Performance-Contracting vs. Non-Performance-Contracting Arrangements........... 19

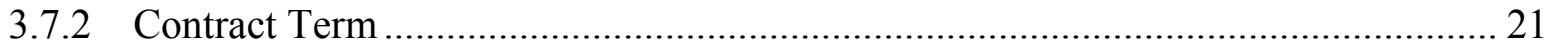

4. Energy Savings: What Energy Savings Have ESCOs Delivered for Typical Projects? ....... 23

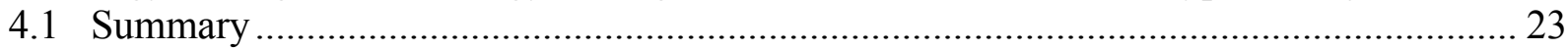

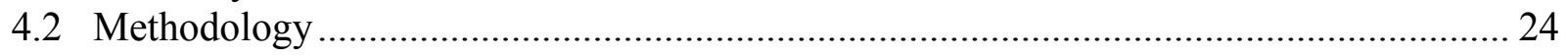

4.2.1 Energy Savings: Actual, Predicted and Guaranteed .................................................. 24

4.2.2 Baseline Metric …………………………….............................................. 25

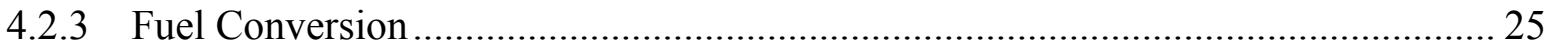

4.3 Average Annual Energy Savings ................................................................................... 26

4.4 Percentage Savings Relative to Baseline Energy Consumption ....................................... 27 


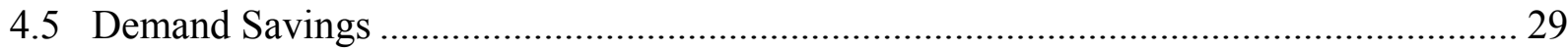

4.6 Predicted vs. Actual Savings................................................................................... 30

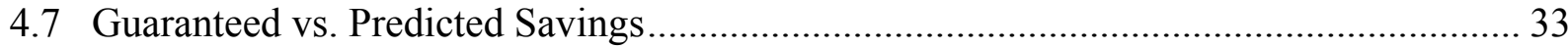

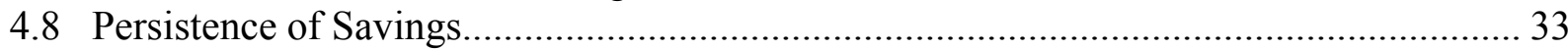

5. Project Economics - What are the Direct Economic Benefits of ESCO Projects from a

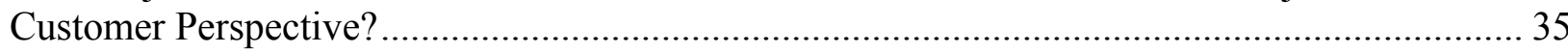

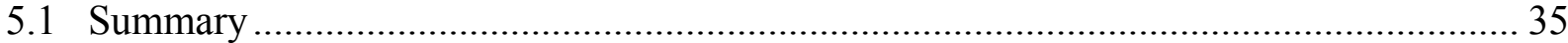

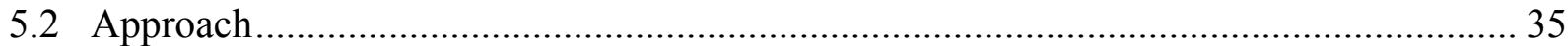

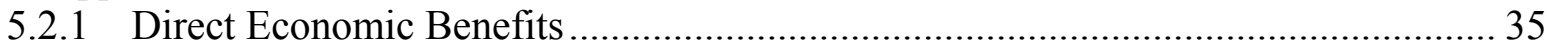

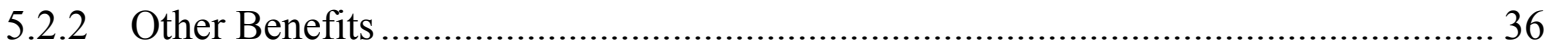

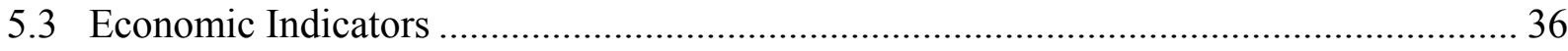

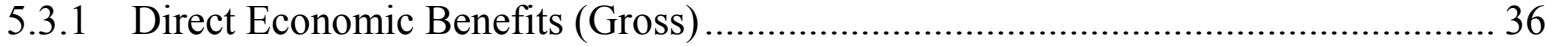

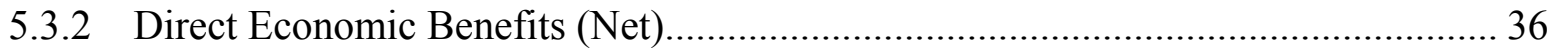

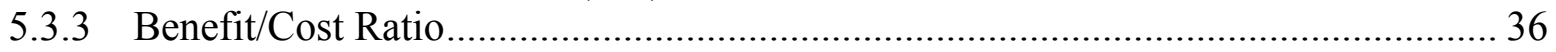

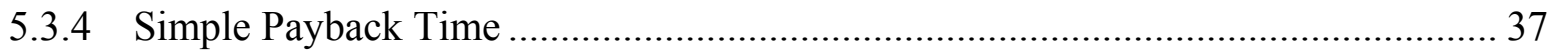

5.4 Direct Economic Benefits and Benefit/Cost Analysis ........................................................ 37

5.5 Simple Payback Time of Institutional and Private Sector Projects .................................. 40

5.6 Other Factors that Influence Project Economics ………................................................... 42

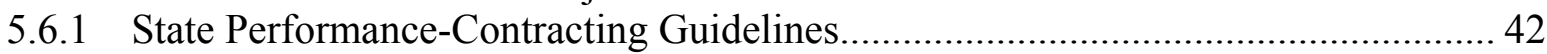

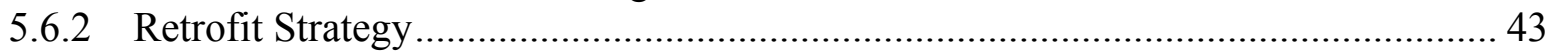

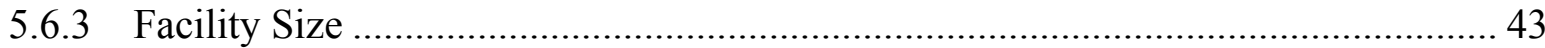

5.6.4 Impact of REEP Incentives on Project Economics ...................................................... 43

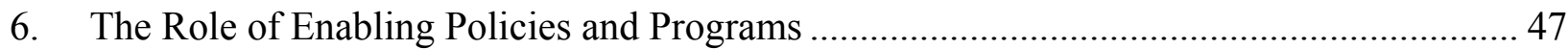

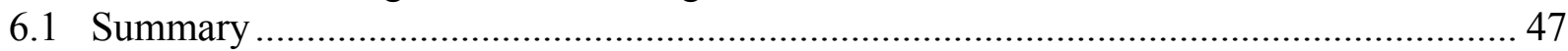

6.2 Ratepayer-Funded Energy Efficiency Programs (REEPs) …………………………....... 48

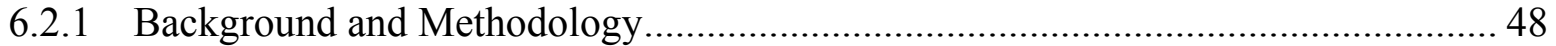

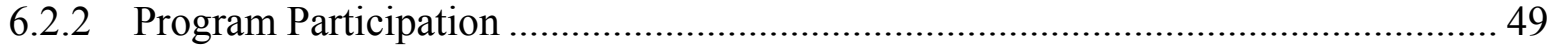

6.2.3 Impact of Financial Incentives......................................................................... 50

6.3 State Policies to Promote Performance Contracting …………………............................ 53

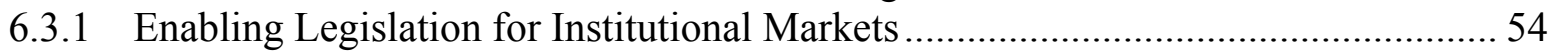

6.3.2 Factors Affecting ESCO Market Activity ............................................................. 56

7. Analysis of Aggregate ESCO Industry Activity ……….................................................... 59

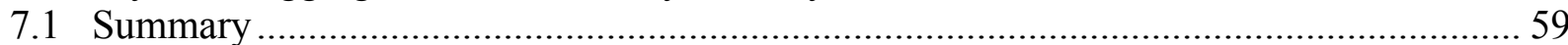

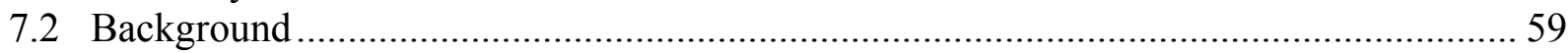

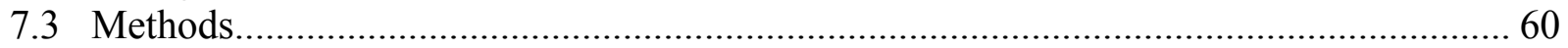

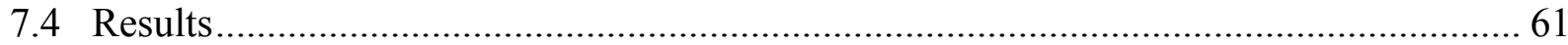

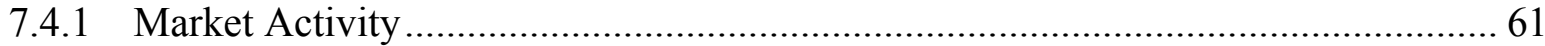

7.4.2 How Representative are Database Projects of Overall ESCO Market Activity?...... 63

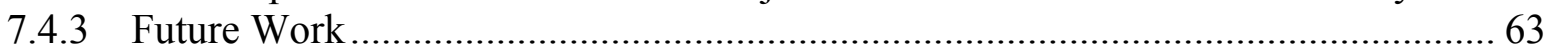

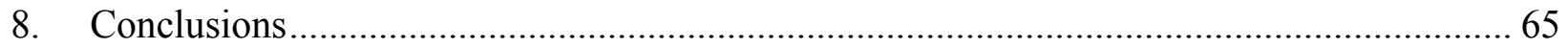

Appendix A: Energy Conservation Measures from Survey ........................................................ 71 
Appendix B: Deployment of Energy-Efficiency Measures by Market Segment

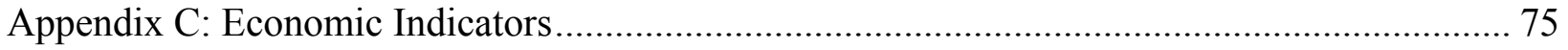

Appendix D: Fuel Prices and Escalation Rates........................................................................... 81

Appendix E: Companies Surveyed for Aggregate Industry Activity …………………............. 83 


\section{List of Figures and Tables}

Figure 3-1. Project Activity by State ........................................................................... 8

Figure 3-2. ESCO Projects Primarily Target Institutional Market Sectors ............................. 10

Figure 3-3. Evolution of ESCO Market Activity.............................................................. 11

Figure 3-4. Range in Project Costs ................................................................................. 15

Figure 3-5. Project Cost by Market Segment....................................................................... 16

Figure 3-6. Project Cost Normalized by Floor Area......................................................... 17

Figure 3-7. Project Cost per Lifetime Energy Savings .......................................................... 19

Figure 3-8. Performance Contracting is a Decreasing Share of ESCO Business ...................... 21

Figure 3-9. Shift in Average Contract Length of Projects ................................................. 22

Figure 4-1. Collection and Aggregation of Project Energy Consumption and Savings Data...... 24

Figure 4-2. Average Annual Energy Savings Normalized by Floor Area $\left(\mathrm{kBtu} / \mathrm{ft}^{2}\right)$................ 27

Figure 4-3. Electricity Savings by Retrofit Strategy............................................................ 28

Figure 4-4. Non-Coincident Peak Demand Savings (\%) ..................................................... 30

Figure 4-5. Relative Accuracy of ESCO Savings Predictions ................................................ 31

Figure 4-6. Actual vs. Predicted Savings by Retrofit Strategy ............................................. 32

Figure 4-7. Difference Between Predicted and Actual Savings by Retrofit Strategy.................. 32

Figure 5-1. Benefit/Cost Ratios for Institutional Sector Projects .......................................... 38

Figure 5-2. Benefit/Cost Ratio of Private Sector Projects .................................................... 40

Figure 5-3. Simple Payback Time of Institutional Sector Projects......................................... 41

Figure 5-4. Simple Payback Time of Private Sector Projects................................................ 42

Figure 5-5. Impact of Ratepayer-Funded Energy-Efficiency Program Incentives on SPT ......... 45

Figure 6-1. ESCO Project Participation Trends in Ratepayer Energy-Efficiency Programs ....... 49

Figure 6-2. ESCO Project Participation in Ratepayer Energy-Efficiency Programs by State...... 50

Figure 6-3. Fraction of Project Costs Paid from Ratepayer Energy-Efficiency Program Incentives

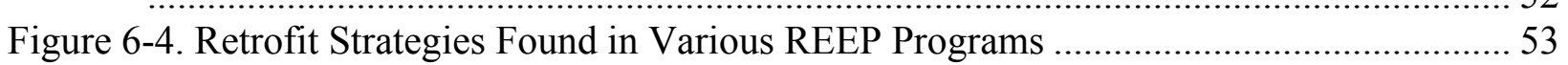

Figure 6-5. State Project Activity in K-12 Schools, Local/State Governments and University/Colleges .............................................................................................. 55

Figure 7-1. Market Activity: ESCO Project Revenues by Source.......................................... 61

Figure 7-2. Aggregate Industry Activity by Company Size ............................................... 62

Table 2-1. Completeness of Key Data Fields in NAESCO Database........................................ 5

Table 2-2. Completeness and Type of Project Energy Savings Data ........................................ 6

Table 2-3. Problems Encountered During Analysis of Database Projects.................................. 6

Table 3-1. ESCO Project Activity Compared to Economic and Market Indicators ..................... 9

Table 3-2. Project Facility Types and Frequency in Database ............................................... 12

Table 3-3. Market Segment Variation of Facility Size ........................................................ 12

Table 3-4. Deployment of Energy-Efficiency Technologies and Strategies ............................ 13

Table 3-5. Intensity of Installed End Use Retrofits by Market Segment.................................. 14

Table 3-6. Project Investment by Retrofit Strategy: Institutional and Private Sectors................ 18 
Table 3-7. Project Investment / Energy Saved by Retrofit Strategy ............................................. 18

Table 3-8. Project Costs by Type of Contract Agreement.............................................................. 21

Table 4-1. Average Annual Electricity Savings by Market Segment....................................... 26

Table 4-2. Annual Electricity and Gas Savings (\%) in Institutional and Private Sectors............. 29

Table 4-3. Demand Savings by Retrofit Strategy ………………………………………......... 29

Table 5-1. Direct Economic Benefits and B/C Ratio for Institutional Sector Projects.................. 37

Table 5-2. Direct Economic Benefits and Benefit/Cost Ratio for Private Sector Projects........... 39

Table 5-3. Impact of Retrofit Strategy on Direct Economic Benefits ........................................... 43

Table 5-4. Impact of Retrofit Strategy on Simple Payback Time............................................... 43

Table 6-1. Measure Categories and Retrofit Strategies by REEP Program Type ......................... 53

Table 6-2. Summary of State Performance-Contracting Legislation............................................ 54

Table 6-3. ESCO Institutional Market Activity and State Promotion of Performance Contracting 57

Table 7-1. Company Size Definitions for Aggregate Activity Survey ......................................... 60

Table 7-2. Potential Biases of Data Collection Methodology ........................................................ 63 


\section{List of Acronyms}

$\begin{array}{ll}\text { CLF } & \text { Conservation Load Factor } \\ \text { Btu } & \text { British Thermal Units } \\ \text { DSM } & \text { Demand-side Management } \\ \text { ECM } & \text { Energy Conservation Measure } \\ \text { ESC } & \text { Energy Services Coalition } \\ \text { ESCO } & \text { Energy Services Company } \\ \text { FG } & \text { Federal Government (market segment) } \\ \text { GO } & \text { State/Local Government (market segment) } \\ \text { GSP } & \text { Gross State Product } \\ \text { HH } & \text { Health/Hospitals (market segment) } \\ \text { HO } & \text { Hotels/Hospitality (market segment) } \\ \text { IN } & \text { Industrial (market segment) } \\ \text { K-12 } & \text { Kindergarten through 12 } 2^{\text {th }} \text { Grade School } \\ \text { LBNL } & \text { Lawrence Berkeley National Laboratory } \\ \text { LO } & \text { Lighting Only Retrofit } \\ \text { LNL } & \text { Lighting and Non-lighting Retrofit } \\ \text { Mbtu } & \text { Million Btu (British thermal units) } \\ \text { M\&V } & \text { Monitoring and Verification } \\ \text { NAESCO } & \text { National Association of Energy Services Companies } \\ \text { NJSPC } & \text { New Jersey Standard Performance Contract (Standard Offer) } \\ \text { NLO } & \text { Non-lighting Only Retrofit } \\ \text { NPV } & \text { Net Present Value } \\ \text { OL } & \text { Offices, Commercial-Leased (market segment) } \\ \text { O\&M } & \text { Operations and Maintenance } \\ \text { OO } & \text { Offices, Commercial-Owned (market segment) } \\ \text { OT } & \text { Other (market segment) } \\ \text { PH } & \text { Public Housing (market segment) } \\ \text { PHA } & \text { Public Housing Authority } \\ \text { RE } & \text { Residential (market segment) } \\ \text { REEP } & \text { Ratepayer-funded Energy-efficiency Program } \\ \text { RFQ } & \text { Request For Qualification } \\ \text { RM } & \text { Retail, Multi-site (market segment) } \\ \text { RS } & \text { Retail, Single Site (market segment) } \\ \text { SC } & \text { K-12 Schools (market segment) } \\ \text { SPC } & \text { Standard Performance Contract } \\ \text { SPT } & \text { Simple Payback Time } \\ \text { UC } & \text { University/colleges (market segment) } \\ & \end{array}$




\section{Executive Summary}

Over the last 20 years, a fairly large private sector energy-efficiency services industry has developed in North America whose primary business is performance contracting. Today, over sixty national and regional Energy Services Companies (ESCOs) are actively operating in the U.S., utilizing savings from investments in high-efficiency equipment to provide solutions to customer needs including facility and equipment modernization, reduced utility expenses, reliable power, and improved control over facility operation and comfort. The U.S. ESCO industry has attracted the interest of federal, state, and international policymakers concerned with promoting successful models for energy efficiency. Although much has been written about this industry, few studies have relied on key underlying empirical data - the track record of ESCOs in developing projects - in order to assess trends in ESCO market activity over time as well as actual project performance and economics from the customer's perspective. This project, a collaborative effort of the National Association of Energy Service Companies (NAESCO), an industry trade association, and Lawrence Berkeley National Laboratory (LBNL) attempts to fill that gap by developing a large database of projects completed by ESCOs. This database of $\sim 1420$ projects represents an investment of $\$ 2.55 \mathrm{~B}$ by 51 companies. In addition to analyzing this data, we have also surveyed active ESCOs in order to develop a comprehensive, historical "snapshot" of the ESCO industry. Our aim is to inform policymakers, customers, companies active in or considering providing energy services, and investors of ESCO market and industry trends, and to examine the impacts of enabling policies that facilitate broad customer access to energy-efficiency services from private sector providers.

\section{Approach}

ESCOs provided information on completed projects as part of NAESCO's voluntary accreditation process. ESCOs that want to be accredited submit an application every 2-3 years, including information on up to 50 energy-efficiency projects completed in the preceding 42month period. The database also includes $\sim 275$ projects submitted by state agencies that administer performance-contracting programs in the institutional market. To ensure data quality and accuracy, we worked with individual ESCOs and state agencies to review project data.

The projects were completed between 1982 and 2001 and include $\$ 2.55$ billion (B) of investment from 51 companies. The sample includes ESCOs for whom performance contracting is a core part of their business, although the database is not limited to performance-contracting projects. Our results are not necessarily representative of the entire energy-efficiency services industry because of the data collection process and because ESCOs self-select projects to submit. For smaller ESCOs, the database typically includes all of their performance-based projects, while for larger ESCOs, the database includes a self-selected sample. Project information provided by ESCOs has been verified through a peer review process and customer reference checks of a subset of projects.

\section{Aggregate ESCO Industry Activity (Chapter 7)}


In order to estimate aggregate industry activity during the 1990-2000 period, we collected information on the market activity of 63 companies that have national or regional operations in the energy-efficiency services industry. We focused on energy efficiency and other value-added services and excluded revenues from electric or gas commodity procurement. Companies that do not offer performance contracting were excluded from our survey, although ESCOs did not have to offer performance-contracting services exclusively. We used various information sources, including interviews with NAESCO member companies $(\mathrm{N}=20)$ and financial information on individual ESCOs from state agency program RFQs $(\mathrm{N}=17)$. We also surveyed several industry experts through a modified delphi approach in order to develop high and low estimates of historic and current market activity of 26 other companies that were identified as ESCOs.

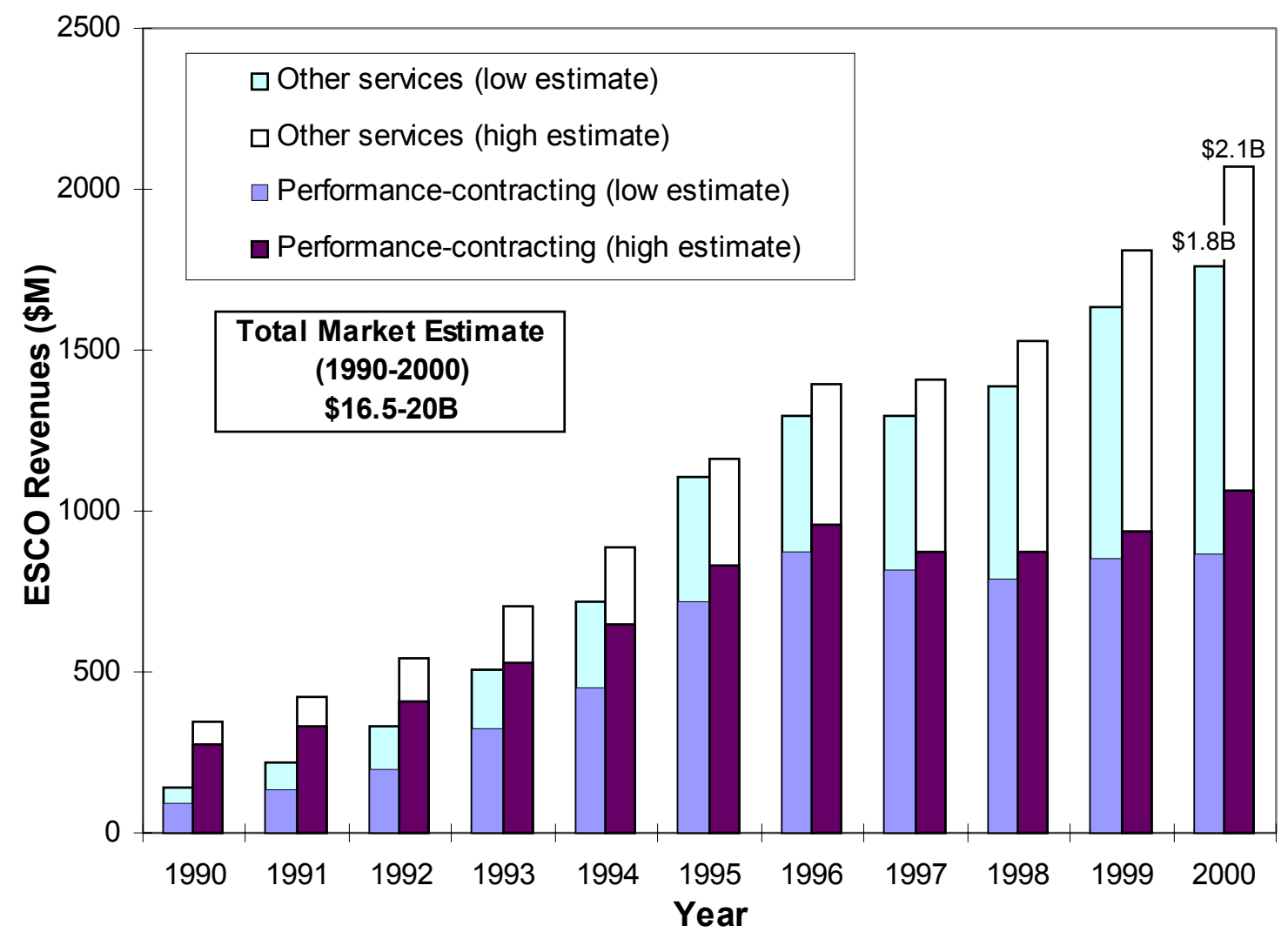

Figure ES-1. Estimated Market Activity of US ESCO Industry

ESCO Industry Revenues Reached $\sim$ 2B/Year In 2000 For Energy-Efficiency Related Services Figure ES-1 shows our low and high estimate of ESCO industry activity between 1990 and 2000. We estimate that ESCO market activity for various energy-efficiency related services ranges between $\$ 1.8$ and 2.1 billion in 2000 . The industry has experienced rapid growth during the last decade with aggregate revenues increasing at a $24 \%$ annualized rate. Growth has slowed since 1996, with 9\% annualized revenue growth over the period 1996-2000. Factors that may explain slower growth rates include the relative maturity and saturation of performance contracting in the institutional market, the upheaval and uncertainties created by electricity restructuring and retail competition in various states, reduced spending on ratepayer-funded energy-efficiency programs, and competition from new entrants such as retail energy service companies. We estimate that 13 companies with annual revenues over $\$ 30$ million (M) account 
for $\sim 75 \%$ of total industry activity. In our high estimate, performance contracting as a fraction these 63 companies' total activity of has dropped from about 74\% (1995 and earlier) to 57\% (1996-2000). The size of the performance contracting market ranges between $\$ 0.9 \mathrm{~B}$ and $\$ 1.2 \mathrm{~B}$ in 2000 . We believe that the $\$ 2.55 \mathrm{~B}$ in investment represented by the $\sim 1420$ projects in our project database represents about $15 \%$ of total ESCO industry activity during the 1990-2000 period.

\section{Typical Project Characteristics (Chapter 3)}

Figure ES-2 shows the range of project costs for 1426 projects in the database, representing an aggregate investment of $\sim \$ 2.55 \mathrm{~B}$. Projects completed since 1996 account for about two-thirds of reported costs. This skew reflects both our intensified data collection efforts and the growth of the ESCO industry in recent years. Median and average project costs are $\$ 0.7 \mathrm{M}$ and $\$ 1.8 \mathrm{M}$ respectively over the entire sample, although projects vary tremendously in size. ESCOs are active in almost all states; four states (New York, New Jersey, California, Texas) account for $44 \%$ of market activity in our sample.

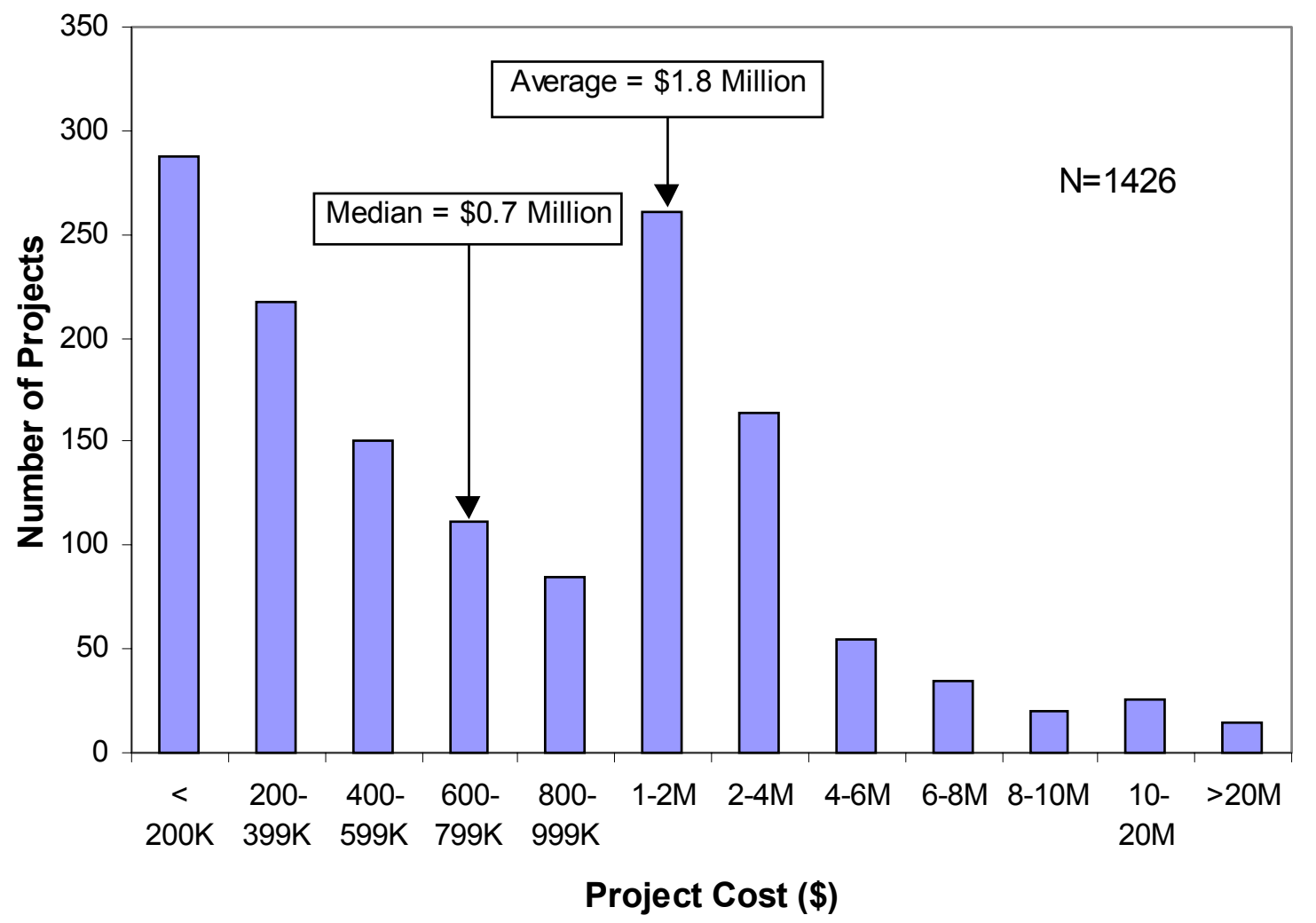

Figure ES-2. Range in Project Costs

ESCOs Focus on Institutional Sector Customers

Approximately $73 \%$ of the projects in the database are from the institutional sector (i.e., K-12 schools, universities, hospitals, and state, local, and federal governments). We believe that this represents an upper bound on ESCO activity in the institutional market for two reasons. First, ESCOs are more reluctant to divulge information on private sector projects. Second, our sample 
also includes about 275 projects that were provided voluntarily by eight state agencies that administer performance-contracting programs.

The range in project costs is quite large, even among projects in the same market segment. Figure ES-3 shows the $25^{\text {th }}$ quartile, median and $75^{\text {th }}$ quartile values for project costs in each market segment. For the middle $50 \%$ of projects in the same market ( $25^{\text {th }}$ to $75^{\text {th }}$ quartile), costs typically vary by a factor of three.

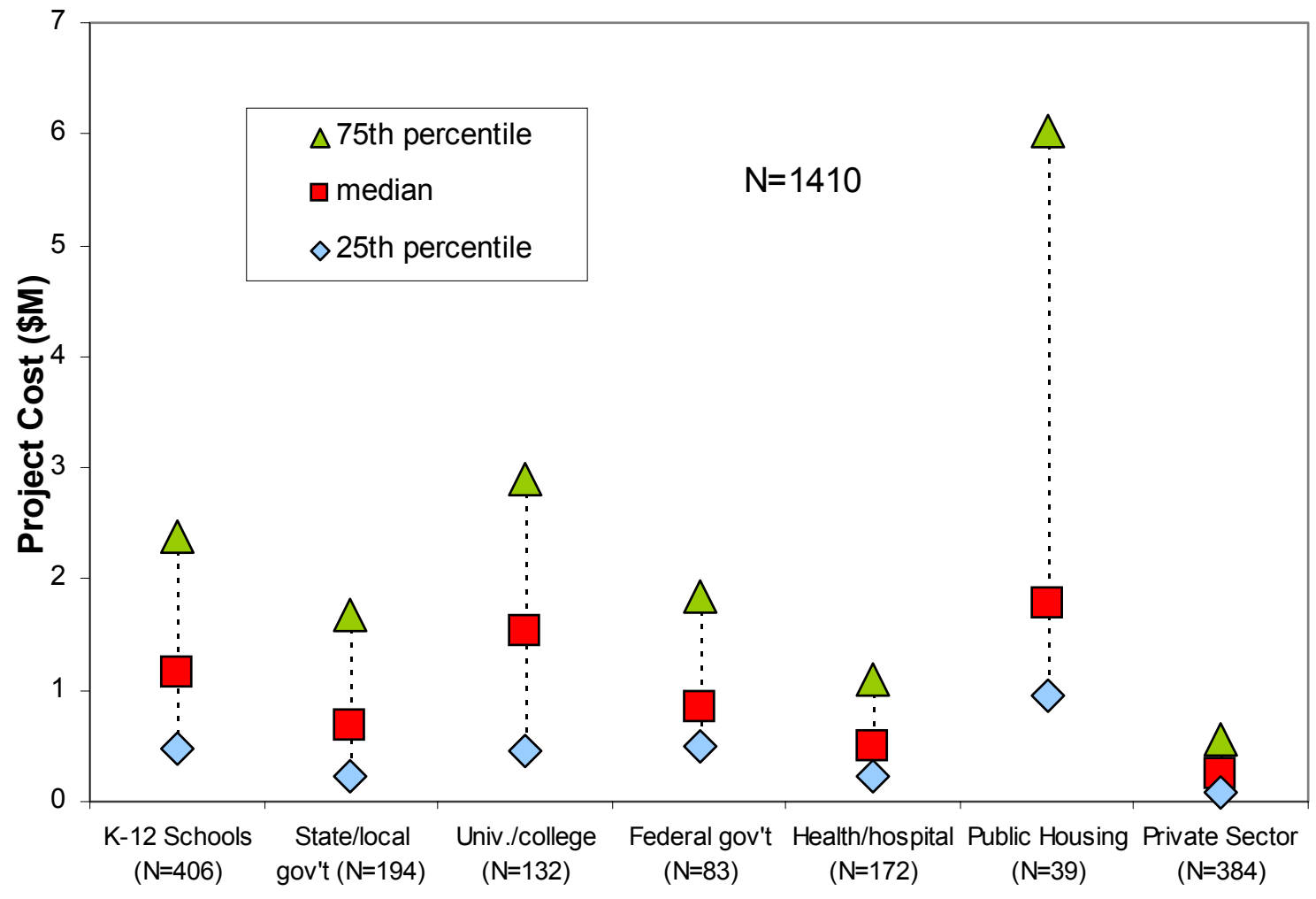

Market Segment

Figure ES-3. Project Cost by Market Segment

Multiple Measures, Multiple End Uses

Almost all projects (95\%) retrofit either lighting or HVAC or both measures. Projects typically install multiple measures or retrofits that target several end uses. Individual energy conservation measures were aggregated into 11 broader "measure categories" for analysis purposes: lighting (installed by $82 \%$ of projects), comfort conditioning (68\%), motors/drives $(23 \%)$, water heaters $(8 \%)$, non-energy improvements $(3 \%)$, power supply $(6 \%)$, refrigeration $(2 \%)$, miscellaneous equipment \& systems (3\%), industrial process improvements (3\%), other measures/strategies $(21 \%)$ and plumbing products \& fittings $(10 \%)$. For certain analyses we divided our sample into three common retrofit strategies: projects that only installed lighting retrofits are designated Lighting Only (LO), projects with any combination of measures not including lighting are Nonlighting Only (NLO), and projects with lighting and other measures are Lighting \& Non-lighting (LNL) projects. Our data suggest that institutional sector projects, on average, target a greater number of measure categories than projects for private sector customers. 
Project Investment Higher in Institutional Markets

Typical project investment is higher in institutional facilities than in private sector projects. This relationship holds true when normalized for floor area, as shown in Figure ES-4. Median values for project investment cost per $\mathrm{ft}^{2}$ are 1.8 times greater in institutional than private sector projects $\left(\$ 2.50 / \mathrm{ft}^{2}\right.$ vs. $\left.\$ 1.40 / \mathrm{ft}^{2}\right)$.

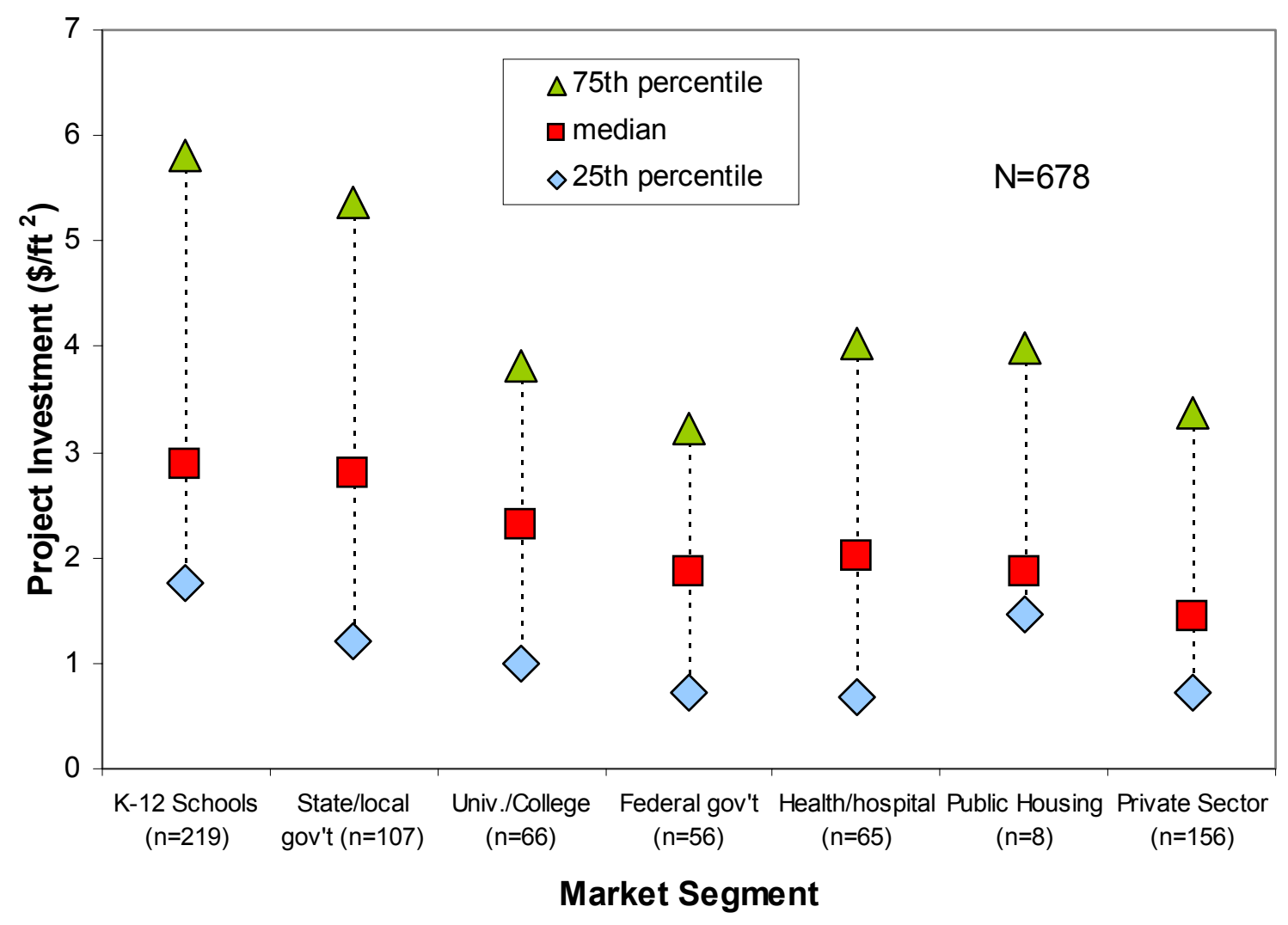

Figure ES-4. Project Cost Normalized by Floor Area

Performance-Contracting Share of Market has Decreased in Recent Years

The market share of performance-contracting projects in our sample has decreased significantly since 1996 , from $92 \%$ to $76 \%$. Over the last decade, there has been an evolution in the types of contractual arrangements utilized by ESCOs and their clients. Guaranteed savings contracts and design/build or fee-for-service arrangements are the most common contracting approaches. Typical duration of contracts in our sample is 10 years, although shorter term contracts $(<5$ years) have become increasingly popular since 1995 ( $20 \%$ of projects during this time period). Contracts lasting more than 15 years account for about $10 \%$ of projects in the database.

\section{Delivered Energy Savings (Chapter 4)}

ESCOs were requested to report baseline consumption as well as predicted and actual, verified savings in energy and/or dollar terms for each project. Reductions in electricity consumption are critically important to project success, accounting on average for over $80 \%$ of total energy savings (on a site energy basis). Median energy savings are $15 \mathrm{kBtu} / \mathrm{ft}^{2}$ for the $29 \%$ of projects that provided sufficient data for this analysis. 
Wide Variation in Typical Energy Savings

Median energy savings (electricity and other fuels) are highest for state/local government and health/hospital projects (18-19 kBtu/ $\left.\mathrm{ft}^{2}\right)$ compared to $13-15 \mathrm{kBtu} / \mathrm{ft}^{2}$ for K-12 schools, university/college, federal government and private sector projects (see Figure ES-5). Note that reported energy savings vary widely. After normalizing for floor area, energy savings typically vary by a factor of 3-5 for the middle $50 \%$ of projects within each market segment (inter-quartile range).

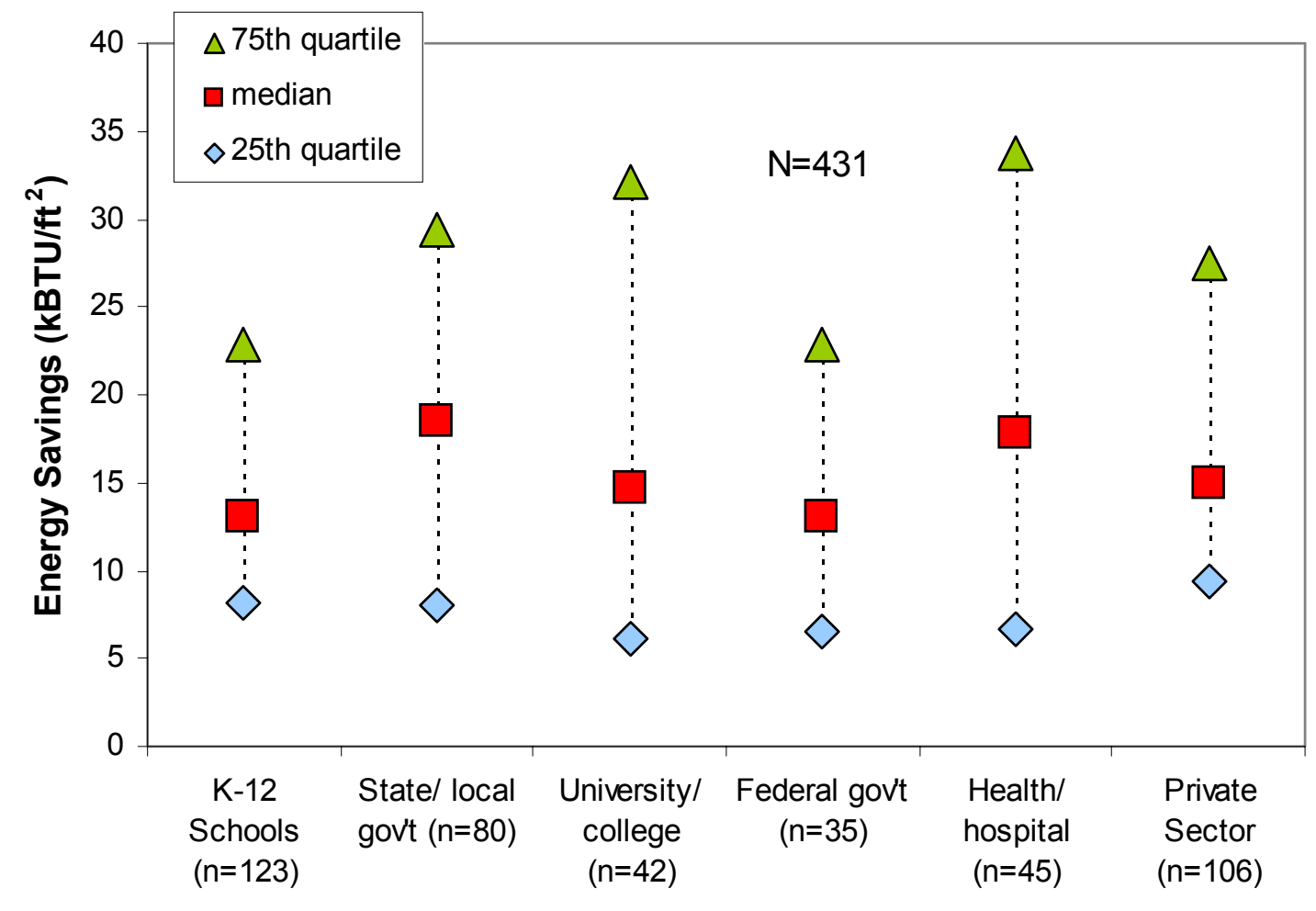

Market Segment

Figure ES-5. Average Annual Energy Savings (kBtu/ft $\left.{ }^{2}\right)$

90\% of Lighting-Only Projects Reduced Lighting Electricity Usage by 30\% or More

Figure ES-6 shows the distribution in percent electricity savings for projects using various retrofit strategies. LO projects report median electricity savings of $47 \%$ of the targeted equipment (with an inter-quartile range of $37 \%$ to $56 \%$ ). These results suggest that ESCOs are achieving significant reductions in lighting energy consumption.

$\sim 85 \%$ of Projects that Installed Lighting \& Non-lighting Measures Reduced Building Electricity Usage by $15 \%$ or More

Projects that install both lighting and non-lighting measures provide an indication of the impact of ESCOs on reducing total electricity bills at facilities. Median electricity savings for LNL projects is $23 \%$ of the total electric bill baseline with a inter-quartile range of $17 \%$ to $32 \%$. 


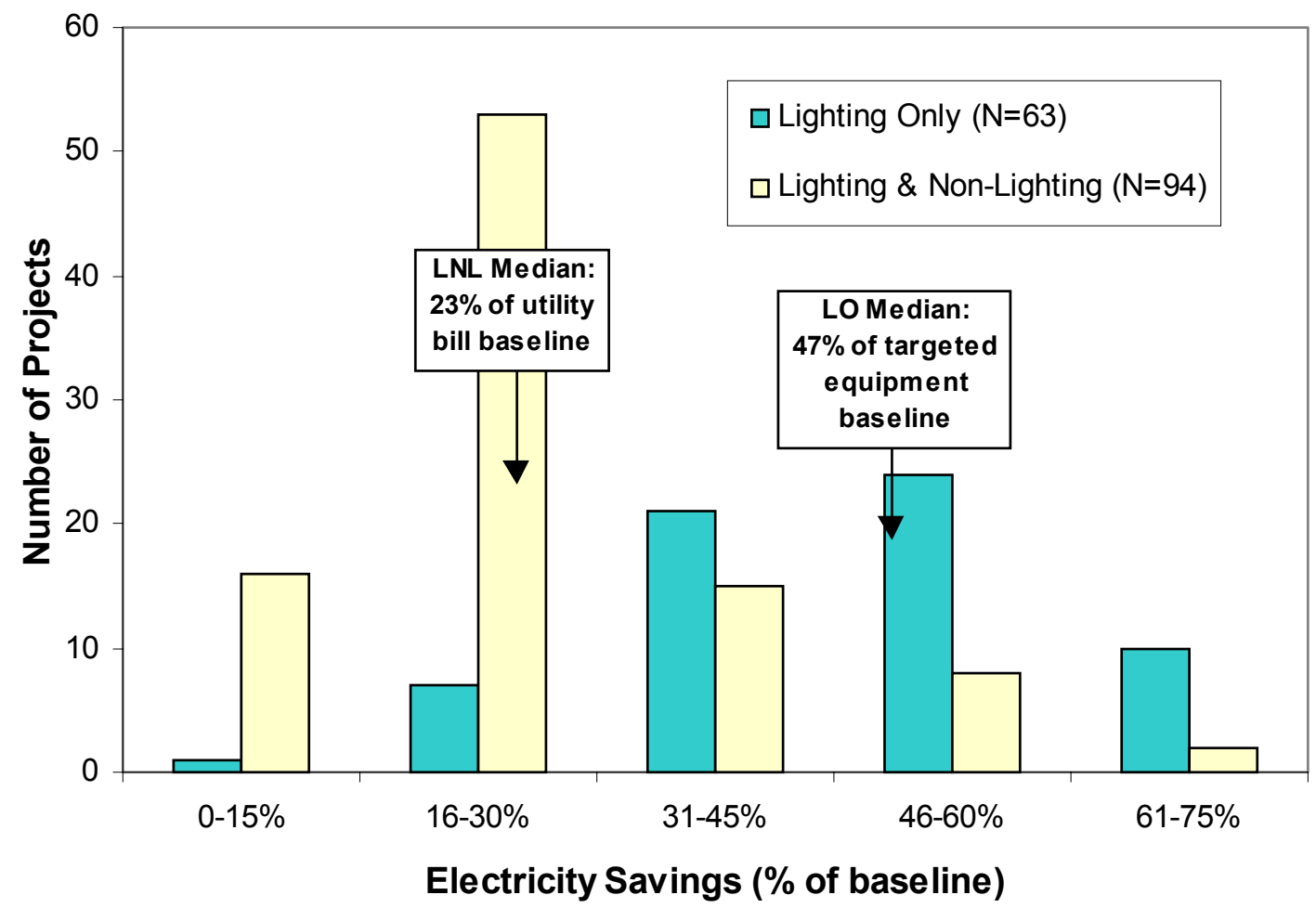

NOTE: All projects in LO sample employ Equipment Targeted baseline metric; LNL sample includes only Utility Bill baseline

Figure ES-6. Electricity Savings by Retrofit Strategy

\section{Accuracy of ESCO Savings Predictions}

The relative accuracy of ESCO savings estimates is of interest to customers, ESCOs, and policymakers. About $28 \%$ of the projects reported both actual and predicted savings (see Figure ES-7). Roughly $60 \%$ of projects realize savings within $15 \%$ of estimates. Fourteen percent of projects stipulated savings for all installed measures (100\% stipulated savings, where actual $=$ predicted savings). For the remaining 314 projects, actual savings exceeded predicted savings in $63 \%$ of the cases.

\section{ESCO Savings Guarantees}

Guaranteed savings is the most popular type of performance-contracting arrangement used by ESCOs. We examined the relationship between savings that were guaranteed to the customer by the ESCO and the ESCO's predicted savings estimates. We found that half (7) of the companies that provided both guaranteed and predicted savings consistently guaranteed $100 \%$ of predicted energy savings. Six of the companies guaranteed between $50 \%$ and $100 \%$ of predicted savings, and two companies actually guaranteed less than $50 \%$ of predicted savings. 


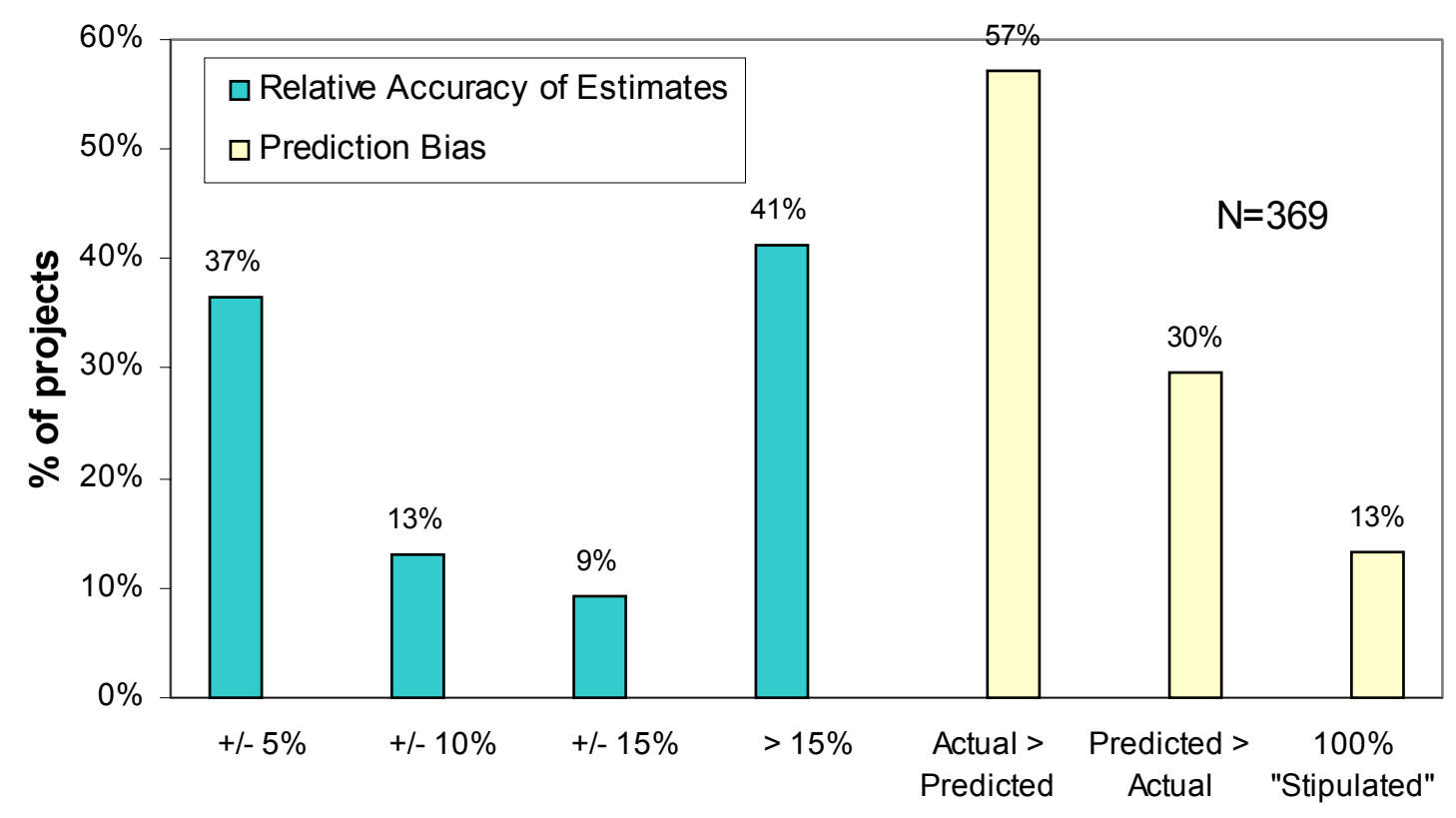

Figure ES-7. Accuracy of ESCO Savings Predictions

\section{Project Economics from the Customer's Perspective (Chapter 5)}

The economic value of ESCO projects is sometimes difficult to quantify because it typically involves estimating both direct (e.g., value of saved energy, O\&M savings) and indirect benefits. ESCO projects may yield a number of indirect benefits such as increased productivity, replacement of aging equipment, improved amenity and comfort levels, and environmental improvements. Because it is difficult to assign a dollar value to indirect or less tangible benefits, our analysis focused only on quantifying the direct economic benefits of ESCO projects. Thus our approach is conservative and is likely to underestimate the actual value of these projects to customers.

Three Indicators: Project Net Benefits, B/C ratio, SPT

For each project, we calculated three economic indicators: net benefits, benefit/cost (B/C) ratio, and simple payback time (SPT).

\section{Effect of Ratepayer-Funded Energy Efficiency Program Incentives}

Roughly $30 \%$ of projects in the database reported receiving financial incentives from a ratepayer-funded energy-efficiency program (REEP). ESCOs often leverage the value of these incentives by passing some or all of the incentive payment directly to the customer, which effectively reduces the cost of the project to the customer. In our base-case economic analysis, we took a conservative approach and did not incorporate the value of these incentives in our calculation of project net benefits or $\mathrm{B} / \mathrm{C}$ ratio. However, we conducted a sensitivity analysis of the impact of REEP incentives on the project's SPT for those projects that received them. For the SPT analysis, we treated incentives from REEP programs in two ways: (1) assume that the customer receives $0 \%$ of the incentives (base-case analysis), and (2) assume that customers 
receive $100 \%$ of the value of rebates and $50 \%$ of the incentives for all other program types (DSM bidding, SPC programs).

\section{Project Net Benefits}

For the 1082 projects with both cost and savings data ( $73 \%$ of the database), net direct economic benefits are $\sim \$ 1.62 \mathrm{~B}$ over the entire sample of 1080 projects using $7 \%$ and $10 \%$ nominal discount rates respectively for institutional and private sector projects (see Tables ES-1 and ES2). Net benefits for the entire sample decrease to $\$ 874 \mathrm{M}$ at higher discount rates. About $90 \%$ of the gross benefits come from energy savings, while about $10 \%$ result from non-energy savings, such as O\&M savings.

Table ES-1. Institutional Sector Project Economics: Benefit/Cost Analysis

\begin{tabular}{|c|c|c|c|c|c|c|c|c|c|c|c|c|}
\hline \multirow{3}{*}{ Market Segment } & \multirow{3}{*}{$\mathbf{N}$} & \multirow{3}{*}{$\begin{array}{c}\text { Total } \\
\text { Project } \\
\text { Costs } \\
(\$ M)\end{array}$} & \multicolumn{5}{|c|}{ 7\% Discount Rate } & \multicolumn{5}{|c|}{$10 \%$ Discount Rate } \\
\hline & & & \multicolumn{2}{|c|}{$\begin{array}{c}\text { Direct Economic } \\
\text { Benefits }(\$ M)\end{array}$} & \multicolumn{3}{|c|}{ Benefit/Cost Ratio } & \multicolumn{2}{|c|}{$\begin{array}{c}\text { Direct Economic } \\
\text { Benefits }(\$ M)\end{array}$} & \multicolumn{3}{|c|}{ Benefit/Cost Ratio } \\
\hline & & & Gross & Net & $25 \mathrm{val}$ & median & $75 \mathrm{val}$ & Gross & Net & $25 \mathrm{val}$ & median & $75 \mathrm{val}$ \\
\hline $\mathrm{K}-12$ schools & 289 & 714 & 803 & 88 & 0.7 & 1.0 & 1.7 & 633 & -81 & 0.5 & 0.8 & 1.3 \\
\hline State/ local gov't & 159 & 276 & 581 & 305 & 1.0 & 1.7 & 3.0 & 471 & 195 & 0.9 & 1.4 & 2.4 \\
\hline Univ./ colleges & 100 & 301 & 809 & 508 & 1.2 & 1.7 & 3.1 & 637 & 336 & 0.9 & 1.4 & 2.4 \\
\hline Federal gov't & 58 & 153 & 280 & 126 & 0.9 & 1.7 & 3.2 & 225 & 72 & 0.8 & 1.4 & 2.6 \\
\hline Health/ hospital & 134 & 136 & 365 & 229 & 1.6 & 2.3 & 3.8 & 295 & 159 & 1.3 & 1.9 & 3.3 \\
\hline Public Housing & 31 & 96 & 140 & 45 & 0.7 & 1.5 & 1.8 & 114 & 18 & 0.6 & 1.2 & 1.4 \\
\hline Institutional Sector & 771 & 1,677 & 2,978 & 1,301 & 0.9 & 1.6 & 2.5 & 2,375 & 698 & 0.7 & 1.3 & 2.0 \\
\hline
\end{tabular}

Table ES-2. Private Sector Project Economics: Benefit/Cost Analysis

\begin{tabular}{|c|c|c|c|c|c|c|c|c|c|c|c|c|}
\hline \multirow{3}{*}{ Market Segment } & \multirow{3}{*}{$\mathbf{N}$} & \multirow{3}{*}{$\begin{array}{c}\text { Total } \\
\text { Project } \\
\text { Costs } \\
(\$ M)\end{array}$} & \multicolumn{5}{|c|}{$10 \%$ Discount Rate } & \multicolumn{5}{|c|}{$15 \%$ Discount Rate } \\
\hline & & & \multicolumn{2}{|c|}{$\begin{array}{c}\text { Direct Economic } \\
\text { Benefits (\$M) }\end{array}$} & \multicolumn{3}{|c|}{ Benefit/Cost Ratio } & \multicolumn{2}{|c|}{$\begin{array}{c}\text { Direct Economic } \\
\text { Benefits (\$M) }\end{array}$} & \multicolumn{3}{|c|}{ Benefit/Cost Ratio } \\
\hline & & & Gross & Net & 25 val & median & 75 val & Gross & Net & 25 val & median & 75 val \\
\hline Commercial* $^{*}$ & 192 & 137 & 349 & 212 & 1.7 & 2.2 & 3.7 & 265 & 128 & 1.3 & 1.7 & 2.8 \\
\hline Industrial & 76 & 95 & 181 & 86 & 1.3 & 1.8 & 2.7 & 136 & 41 & 1.0 & 1.4 & 2.2 \\
\hline Other ${ }^{* *}$ & 41 & 28 & 47 & 18 & 0.8 & 1.8 & 2.7 & 34 & 6 & 0.7 & 1.3 & 2.0 \\
\hline Private sector & 309 & 260 & 576 & 317 & 1.4 & 2.1 & 3.2 & 435 & 176 & 1.1 & 1.6 & 2.6 \\
\hline
\end{tabular}

${ }^{*}$ Commercial includes hotels/hospitality, retail space, and commercial offices.

${ }^{* *}$ Other includes residential and projects that were classified as "other" by the ESCO.

The Vast Majority of ESCO Projects are Cost-Effective (B/C ratio greater than one) About $87 \%$ of the 309 private sector projects and $70 \%$ of the 771 institutional sector projects have $\mathrm{B} / \mathrm{C}$ ratios greater than one. The median $\mathrm{B} / \mathrm{C}$ ratio is 1.6 for institutional sector projects using a $7 \%$ nominal discount rate and 1.3 at a $10 \%$ discount rate (see Table ES-1). The median $\mathrm{B} / \mathrm{C}$ ratio ranges between 2.1 and 1.6 for private sector projects, depending on choice of discount rate (see Table ES-2).

Simple Payback Time (SPT)

The median SPT is about seven years for the institutional sector. About $44 \%$ of institutional sector projects have a SPT of six years or less. The median SPT is about three years for private sector projects. About $83 \%$ of private sector projects have a SPT of six years or less. 
We compared SPT for projects grouped by retrofit strategy and market sector in Table ES-3. First, note the higher share of LO projects in the private sector compared to the institutional market (43\% vs. 20\%). Second, median payback times for LO projects were relatively short in both institutional and private sector projects ( 2 years). Third, median payback times, however, are significantly longer for LNL and NLO projects in the institutional sector than the private sector ( 8 vs. 4 and 2 years). As these retrofit strategies are quite broad, it appears that private sector projects selectively focus on individual measures with shorter payback times.

Table ES-3. Impact of Retrofit Strategy on Simple Payback Time

\begin{tabular}{|l|c|ccc|cc|cc|}
\hline \multirow{3}{*}{ Retrofit Strategy } & \multicolumn{6}{c|}{ Simple Payback Time (years) } \\
\cline { 2 - 9 } & \multicolumn{3}{|c|}{ Institutional Sector } & \multicolumn{4}{c|}{ Private Sector } \\
& $\mathrm{N}$ & 25 val & median & 75 val & $\mathrm{N}$ & 25 val & median & 75 val \\
\hline Lighting Only & 146 & 1 & 2 & 4 & 128 & 1 & 2 & 4 \\
Lighting \& Non-Lighting & 498 & 5 & 8 & 13 & 97 & 3 & 4 & 6 \\
Non-Lighting Only & 98 & 2 & 8 & 14 & 73 & 1 & 2 & 5 \\
\hline
\end{tabular}

This analysis suggests that choice of retrofit strategy and state or federal legislation that specifies maximum terms for performance contracts may influence project economics. Many states specify the maximum contract term for a performance contract in their enabling legislation. The underlying intent of these provisions is to articulate the state's willingness to undertake comprehensive projects that install and finance high-efficiency equipment and other measures up to a cost-effectiveness threshold. The maximum contract term allowed by states is as follows: 2 states allow 5-6 year contract terms, 13 states allow 10 year contracts, 2 states allow 12 year contracts, 9 states allow 15 year contracts, 5 states allow 18-20 year contracts, and five states allow 25 or more year contracts. Given the fact that 34 states allow maximum contract terms of 10 or more years, it should not be surprising that energy-efficiency equipment and measures that are installed in institutional sector projects have long expected economic lifetimes and payback times.

\section{The Role of Enabling Policies and Programs (Chapter 6)}

Policies and programs supported by state public utility commissions (e.g., energy-efficiency programs) and state or federal legislatures and agencies (e.g., enabling legislation and rules for performance contracting) have played an important role in stimulating ESCO activity in various markets. ESCOs were requested to provide information on project participation in ratepayerfunded energy-efficiency programs (REEPs).

ESCO Project Participation in Ratepayer-Funded Energy-Efficiency Programs (REEPs) Decreasing Since 1996

Participation in REEPs by ESCOs has been decreasing in the last five years. Of the projects completed prior to and including 1995, 50\% are part of a REEP compared to 34\% of the projects completed between 1996-2001. The most commonly reported types of energy-efficiency program are Standard Performance Contract (SPC) ${ }^{1}$, rebate, and DSM bidding. Rebates were the most ubiquitous, reported for projects in 26 states, but SPC programs represent the largest program in terms of financial incentives paid to ESCOs and customers. Projects participating in

\footnotetext{
${ }^{1} \mathrm{SPC}$ and Standard Offer programs are essentially the same in terms of program design.
} 
REEPs received $\sim \$ 310 \mathrm{M}$ of financial incentives which were used to buy down the costs of these projects, estimated at $\$ 532 \mathrm{M}$.

Incentive Levels Vary Widely

Incentives provided in rebate, recent Standard Performance Contract (SPC), ${ }^{2}$ and DSM bidding programs were typically less than $50 \%$ of project costs. The median incentive level to project cost ratios were $12 \%, 28 \%$ and $38 \%$ respectively for the three types of programs. However, financial incentives for most projects that participated in the New Jersey Standard Offer program significantly exceeded the cost to install the project. Differences in incentive levels between different types of REEP (e.g., SPC vs. rebate programs) are related to the program's overall goals and objectives, the utility's avoided cost of supply, and retail rates (which affect customer payback time).

State Legislation and Active Energy Program Offices Facilitate Performance Contracting in Institutional Market

Most states allow or encourage performance-contracting projects in certain public institutional markets: K-12 schools, state/local governments, and university/colleges (Figure ES-9). Only four states have no such legislation for at least one of these market segments. Our sample of institutional sector projects suggests that the amount of performance contracting activity in K-12 schools, university/college, and state/local government market segments is affected by a state's overall market potential, favorable enabling legislation or procurement rules for performance contracting, and active support from state energy program offices. Favorable performance contracting legislation may have the most impact in states with medium to smaller size institutional markets that might not otherwise attract ESCO interest (e.g., Indiana, Washington, Kentucky).

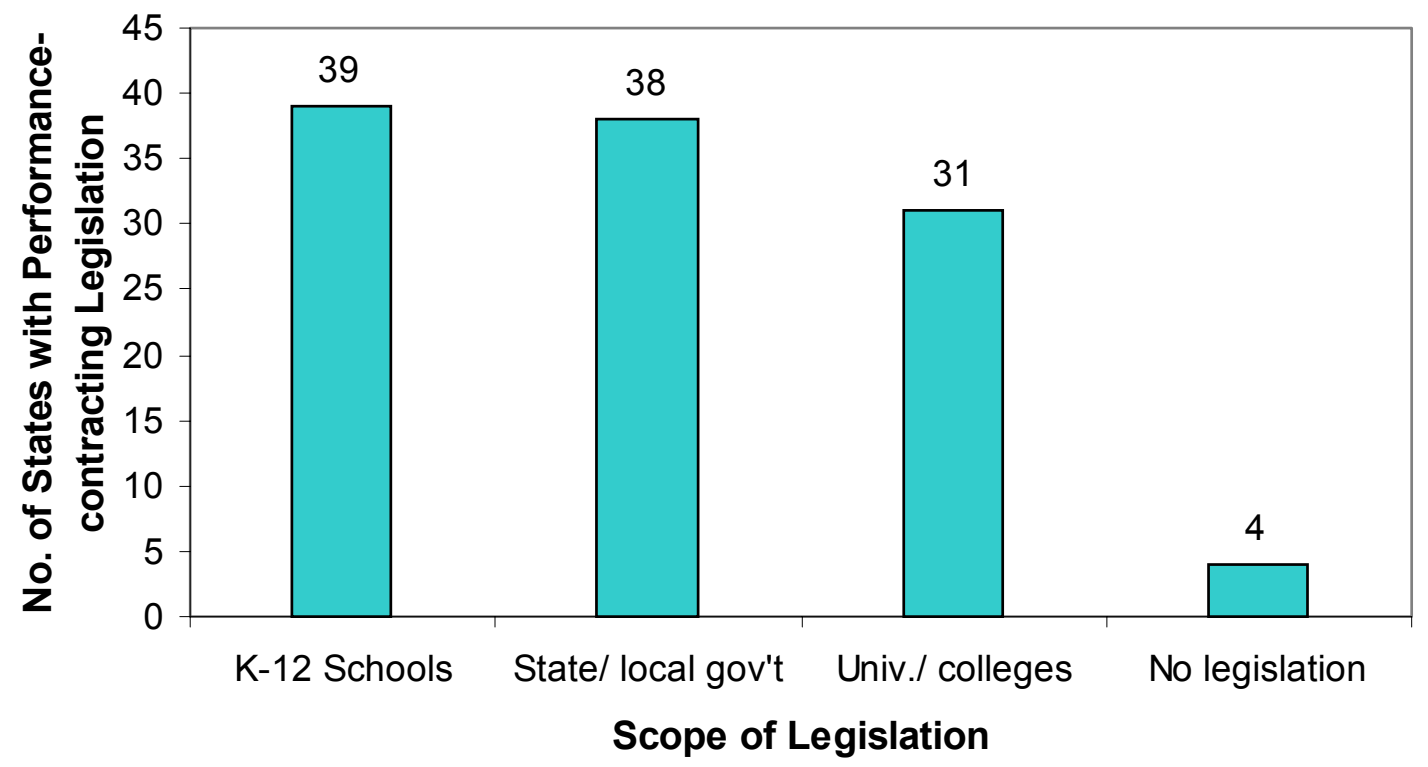

Figure ES-9. Most States Promote Performance Contracting with Legislation

\footnotetext{
${ }^{2}$ Not including projects that were part of the New Jersey Standard Offer program.
} 
xxiv 


\section{Introduction}

Over the last 20 years, a fairly large private sector energy-efficiency services industry has developed in North America whose primary business is performance contracting. Today, over sixty national and regional Energy Services Companies (ESCOs) are actively operating in the United States, utilizing savings from investments in high-efficiency equipment to provide solutions to customer needs such as facility and equipment modernization, reduced utility expenses, reliable power, or improved control over facility operation and comfort. ${ }^{3}$ The U.S. ESCO industry has attracted the interest of federal, state, and international policymakers interested in promoting successful models for energy efficiency. Although much has been written about the U.S. ESCO industry, few studies have relied on key underlying empirical data - the track record of ESCOs in developing projects - in order to assess the actual performance, savings, and economics of projects completed by ESCOs or trends in ESCO market activity over time (Dayton et al 1998; Goldman et al 1996). Policymakers and investors interested in the industry have been hindered by limited data on actual performance of projects to support industry claims.

This project, a collaborative effort of the National Association of Energy Service Companies (NAESCO), an industry trade association, and Lawrence Berkeley National Laboratory (LBNL) attempts to fill that gap by developing a large database of projects completed by ESCOs. Project information is provided on a voluntary basis by ESCOs and state agencies and includes information on project characteristics, costs, and savings. About $80 \%$ of the projects in the database involve performance-contracting arrangements between ESCOs and customers. In this study, we analyze results from $\sim 1500$ projects, representing an investment of $\$ 2.55 \mathrm{~B}$ by 51 companies in order to develop a comprehensive, historical "snapshot" of the ESCO industry.

Our analysis provides insights on the evolution and performance of the U.S. ESCO industry that will aid state, federal, and international policymakers and other investors interested in the development of a private sector energy-efficiency services industry. Specifically, the database of projects enables us to:

- track industry progress and trends over time (geographically and by market segment);

- assess technical and financial impacts of the industry and typical projects (e.g., electricity and fuel savings, peak demand reductions, predicted versus actual savings, and economic benefits to customers); and

- analyze the effects of policies (e.g., impact of state policies that allow or facilitate performance contracting in institutional markets, extent of reliance on utility DSM or public purpose programs).

This study updates Goldman, et al (2000). Since that initial report, 700 new projects have been added. In addition, this study includes more detailed information on project characteristics,

\footnotetext{
${ }^{3}$ The energy-efficiency services industry includes several types of entities that design, construct and implement projects at customer facilities, including ESCOs, equipment and lighting contractors, and architects/engineering consulting firms. ESCOs are project developers that integrate a full range of energy-efficiency services. A distinctive feature of ESCOs is their use of performance contracting: the costs of a project are repaid out of the energy and cost savings over the expected lifetime and the ESCOs assumes risk for the delivery of promised energy or cost savings.
} 
expanded reporting of energy savings, analysis of project economics, and estimates of aggregate ESCO industry activity.

The report is organized as follows. Section 2 describes data sources, information requested from ESCOs or state agencies on each project, and methods used to ensure data quality and accuracy. Section 3 summarizes information on project characteristics: type of facilities and customers, floor area, energy-efficiency measures installed as part of the project, project costs, and contract structure and term. Section 4 reports and analyzes energy savings achieved by ESCOs. Section 5 analyzes the economic benefits and costs of ESCO projects from the customer's perspective, focusing on several economic indicators (project net benefits, benefit/cost ratio, and simple payback time). Section 6 discusses leveraging provided by ratepayer-funded energy-efficiency programs and the impact of state policies that enable or facilitate performance contracting in public institutional markets. Section 7 presents our analysis of aggregate ESCO industry market activity from 1990 to 2000 . 


\section{Data Sources and Methodology}

\subsection{Summary}

- This database of $\sim 1500$ projects represents the largest compilation of the actual, documented performance of the ESCO industry. Projects have been submitted voluntarily by ESCOs as part of the National Association of Energy Service Companies (NAESCO) accreditation process and by state agencies.

- Because of the data collection process and because ESCOs self-select projects to submit, our results are not necessarily representative of the entire energy-efficiency services industry. For smaller ESCOs, the database typically includes all of their performance-based projects, while for larger ESCOs, the database includes a self-selected sample. Project information provided by ESCOs has been verified through a quality assurance review process and customer reference checks of a subset of projects.

\subsection{Data Sources}

The database was developed as a collaborative effort between NAESCO and LBNL. ESCOs provided project information as part of NAESCO's periodic accreditation process and are required to submit information on up to 50 energy-efficiency projects completed in the preceding 42-month period. ${ }^{4}$

NAESCO/LBNL requested that ESCOs provide the following information on all submitted projects:

- Project location: city, state, zip code, country.

- Customer contact: name, phone, email.

- Project characteristics: date of completion, floor area, number of buildings, market segment, facility type.

- Project economics: cost with and without financing, project agreement type, contract term, monitoring period, and utility DSM or public purpose program type and incentives (if applicable).

- Baseline annual energy consumption: baseline metric, electricity consumption, peak demand, natural gas consumption, other fuel consumption and water use - all in units of energy/water or as a dollar value.

- Annual energy savings: predicted, guaranteed and actual (i.e., measured) savings of electricity, peak demand, natural gas, other fuels and water - all in units of energy/water or as a dollar value.

- Other benefits: Operations and Maintenance (O\&M) and other non-energy dollar savings over the project lifetime.

- Measures installed: selected from a list.

\footnotetext{
${ }^{4}$ This time period is for renewal applicants; new applicants can submit projects up to five years old. The requirement of 50 projects began in fall 2000 .
} 
Projects are self-reported by companies and the data collection process has evolved over the six years that accreditation has been offered by NAESCO. ${ }^{5}$ For smaller companies, the 50-project requirement typically represents all of their performance-based projects. However, for larger ESCOs, the 50 projects may represent only a small fraction of their total business. ${ }^{6}$ NAESCO also requests that ESCOs submit projects that are representative of the company's total business. However, because the Accreditation Committee checks and interviews a sample of project references, ESCOs have an incentive to select their best projects. Because of concerns over customer confidentiality, there may also be a tendency among ESCOs to report public sector projects more readily than those completed in the private sector. NAESCO also requests that the majority of the projects be performance-based, which means our sample of projects is skewed towards performance-contracting approaches. Finally, ESCOs have tended to provide more detailed information on recently completed projects than projects completed prior to 1998, in part because less information was required during the initial rounds of accreditation.

We also surveyed and requested project information from various state agencies that administer performance-contracting programs in the institutional market. Eight agencies agreed to provide project data that met our minimum data requirements: Kentucky Department of Education, New York State Energy Research and Development Authority, Michigan Department of Consumer and Industry Services, Illinois Department of Commerce and Community Affairs, Colorado Office of Energy Management and Conservation, Ohio Office of Energy Efficiency, Rhode Island State Energy Office, and Washington State Department of General Administration. These agencies provided 259 projects, representing $17 \%$ of the database. We also obtained leads and information on completed performance-contracting projects from: publicly available Request for Qualifications (RFQs) or Proposals issued by state agencies, literature reviews of the trade press, industry experts, and contacts at individual ESCOs.

\subsection{Data Quality and Confidentiality}

In return for voluntarily providing data on completed projects, we agreed that certain customer and company information would be treated as confidential. Specifically, we agreed that the identity, project characteristics, and results of individual customers would not be revealed or reported. We also agreed to identify individual ESCOs that provided project data without linking that information to specific performance or results for individual companies.

We took a number of steps to ensure data quality and consistency, which can be challenging when collecting confidential data from diverse sources over an extended time period. We developed an electronic form for data collection, which includes required and desired information for each project. Individual fields include a description, definition and often a

\footnotetext{
${ }^{5}$ Early accreditation rounds requested detailed information on 10 projects and less specific summary information on 50 additional projects. As a practical matter, this means there are more new $(1996+)$ projects in the database and that newer projects are often more detailed and the data are of better quality than older ones.

${ }^{6}$ These project reporting requirements mean that our sample of projects are not necessarily representative of the ESCO industry in aggregate because the activities of larger ESCOs are under-represented.
} 
standardized menu of choices. ${ }^{7}$ After projects were submitted by ESCOs or state agencies, we reviewed project data for accuracy, completeness, and internal consistency, performed quality assurance checks, and often requested that companies clarify data or provide missing information. Finally, a subset of customers was called to verify the accuracy of information submitted by ESCOs as part of the NAESCO accreditation process.

Despite our attempt to collect standardized, consistent and complete information on individual projects, it should be noted that many projects in the database are missing information that would be quite useful in our analysis (see Table 2-1). For example, only $46 \%$ of projects provided information on floor area, and only $37 \%$ provided data on baseline energy consumption. These data limitations reduce our sample size in the analysis of factors that may explain variation in project performance across projects and market sectors (e.g., normalizing and accounting for differences in savings $/ \mathrm{ft}^{2}$ or pre-retrofit consumption levels).

Table 2-1. Completeness of Key Data Fields in NAESCO Database

\begin{tabular}{|l|c|}
\hline \multicolumn{1}{|c|}{ Data field } & $\begin{array}{c}\text { Percent of projects } \\
\text { completed (N=1489) }\end{array}$ \\
\hline Project cost & $96 \%$ \\
Market segment & $99 \%$ \\
Year of completion & $90 \%$ \\
Floor area & $46 \%$ \\
REEP participation & $83 \%$ \\
Installed measures & $93 \%$ \\
Contract term & $55 \%$ \\
Project agreement type & $53 \%$ \\
Baseline consumption & $37 \%$ \\
Predicted savings & $68 \%$ \\
Actual, verified savings & $61 \%$ \\
\hline
\end{tabular}

Data on project savings illustrates the issues related to missing and non-standardized reporting of project information. For example, we requested that ESCOs provide info on project energy savings, and 759 projects complied. However, for 486 projects, ESCOs only provided the dollar value of savings rather than energy units such as $\mathrm{kWh}$, therms, etc. (see Table 2-2). We used this information in our economic analysis, but were unable to include these projects in our energy savings analysis. Similarly, ESCOs reported only predicted, not actual, savings for 213 projects, in many cases because the projects were completed recently.

In the future, increased sample size and continued improvements in the quality, consistency and completeness of project data will allow us to conduct a more comprehensive analysis of several key questions that we were unable to pursue beyond an exploratory analysis at this stage (see Table 2-3).

\footnotetext{
${ }^{7}$ Examples include standardized definitions for market segments, project contracting approaches and financial arrangements, information on DSM program participation and methods used to develop energy consumption baselines.
} 
Table 2-2. Completeness and Type of Project Energy Savings Data

\begin{tabular}{|c|c|c|}
\hline \multirow{2}{*}{$\begin{array}{l}\text { Type of savings } \\
\text { used in analysis }\end{array}$} & \multicolumn{2}{|c|}{ No. of projects reporting: } \\
\hline & Energy units* & Dollars only \\
\hline Actual $^{\star \star}$ & 546 & 236 \\
\hline Predicted & 213 & 250 \\
\hline Total & 759 & 486 \\
\hline
\end{tabular}

* some projects reported savings in both energy units (e.g., kWh, therms) and dollars

${ }^{* *}$ some projects reported both actual and predicted savings

Table 2-3. Problems Encountered During Analysis of Database Projects

\begin{tabular}{|l|l|}
\hline \multicolumn{1}{|c|}{ Exploratory analysis } & \multicolumn{1}{c|}{ Data problem } \\
\hline Persistence of savings & Completeness of data \\
\hline $\begin{array}{l}\text { Percent savings relative to baseline } \\
\text { usage }\end{array}$ & $\begin{array}{l}\text { Standardization; completeness } \\
\text { of data }\end{array}$ \\
\hline Saturation of individual ECMs & Standardization, completeness \\
\hline $\begin{array}{l}\text { Ongoing Operations \& Maintenance } \\
(\mathrm{O} \& \mathrm{M}) \text { and measurement/verification } \\
(\mathrm{M} \& \mathrm{~V}) \text { costs }\end{array}$ & Completeness of data \\
\hline Repeat business & Sample size \\
\hline
\end{tabular}




\section{Project Characteristics}

\subsection{Summary}

- There are 1420 projects in the database that reported information on project costs, representing $\sim \$ 2.55 \mathrm{~B}$ of investment. ESCOs are active in almost all states in the U.S. In our sample, four states (New York, New Jersey, California, Texas) provide the strongest representation, accounting for $44 \%$ of market activity.

- About $74 \%$ of the projects in the database are from the institutional sector (i.e., schools, universities, hospitals, and state, local, and federal governments). We believe that this fraction represents an upper bound on industry activity in the institutional market because ESCOs are more reluctant to divulge information on private sector projects and because our sample includes projects that were provided voluntarily by eight state agencies that administer performance-contracting programs.

- Almost all projects (95\%) have retrofitted either lighting or HVAC or both. Projects typically install multiple measures or retrofits that target several end uses. Individual energy conservation measures were aggregated into 11 broader "measure categories" for analysis purposes. Our data suggest that institutional sector projects, on average, target a greater number of measure categories than projects for private sector customers.

- Typical project investment is higher in institutional than private sectors. This relationship holds true when normalized for floor area. Median investment values are 1.8 times greater in institutional than private sector projects $\left(\$ 2.50 / \mathrm{ft}^{2}\right.$ vs. $\left.\$ 1.40 / \mathrm{ft}^{2}\right)$.

- The market share of performance-contracting projects in our sample has decreased significantly since 1996 from $92 \%$ to $76 \%$. Over the last decade, there has been an evolution in the types of contract agreements utilized by ESCOs and their clients: guaranteed savings and design/build, fee-for-service arrangements are the most common contracting approaches. Typical duration of contracts in our sample is 10 years, although shorter term contracts $(<5$ years) have become increasingly popular since 1995 ( $20 \%$ of projects during this time period).

\subsection{Geographic Activity}

Most ESCOs rely primarily on regional or local offices for business development and project implementation (Easton Management Consultants 1999). In establishing such offices, ESCOs may consider the following factors: market potential of targeted sectors, economic activity, population density and building stock, existing and projected energy costs, and favorable regulatory or state policies (e.g., ratepayer-funded energy-efficiency programs, or legislation that allows or encourages performance contracting in competitive procurement processes for public sector).

For each project, we collected information on its location. Figure 3-1 shows market activity by state measured in terms of project costs for the 1393 projects that provided this information. 


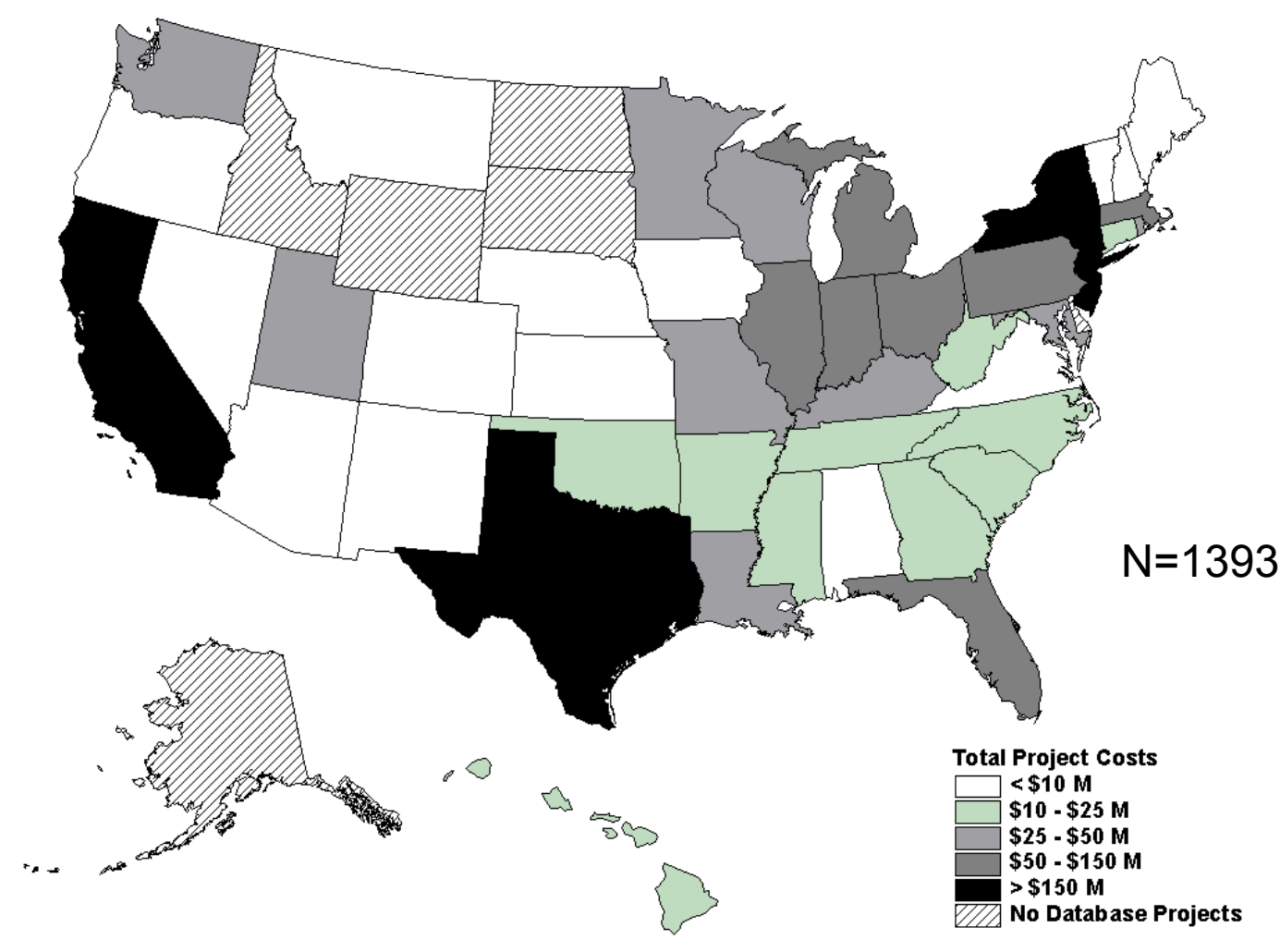

Figure 3-1. Project Activity by State

Four states (New York, New Jersey, California, Texas) provide the strongest representation, accounting for $44 \%$ of market activity for projects in the database (i.e., $\$ 1.0 \mathrm{~B}$ of $\sim \$ 2.6 \mathrm{~B}$ ).

Table 3-1 lists and ranks the 10 states with the most project activity in our sample and compares their ranking in terms of aggregate economic activity, population, and funding levels for energyefficiency programs. We would expect states that rank high in economic activity and population to be attractive markets for ESCOs. Our data on ESCO project activity tends to support this view (e.g., New York, California, and Texas). Some ESCOs have also tended to focus their activities in states that provided strong support for ratepayer-funded energy-efficiency programs (or performance-contracting programs in public sector markets). Our project data provide support for this view as evidenced by the substantial ESCO market activity in New Jersey and Massachusetts where there have been well-funded energy-efficiency programs for many years. The role of ratepayer-funded energy-efficiency programs and enabling state policies is examined in more detail in Chapter 6. ESCOs are also quite active in a number of states (e.g., Indiana, Illinois, Ohio, and Pennsylvania) which are relatively large centers of economic activity and population, but have not historically supported large ratepayer-funded energy-efficiency programs. There are several states with no projects in the database; these states have low population density and little ESCO activity would be expected (see Figure 3-1). 
Table 3-1. ESCO Project Activity Compared to Economic and Market Indicators

\begin{tabular}{|c|c|c|c|c|c|c|c|c|}
\hline \multirow{2}{*}{ State } & \multicolumn{2}{|c|}{ ESCO Project Costs } & \multicolumn{2}{|c|}{$\begin{array}{c}\text { Economic Activity } \\
(1999 \text { GSP })^{*}\end{array}$} & \multicolumn{2}{|c|}{ Population $(2000)^{\star *}$} & \multicolumn{2}{|c|}{ REEP*** } \\
\hline & $\operatorname{Rank}^{\dagger}$ & $(\$ M)$ & $\operatorname{Rank}^{\dagger}$ & $(\$ B)$ & $\operatorname{Rank}^{\dagger}$ & $\begin{array}{l}\text { (million } \\
\text { people) }\end{array}$ & Rank $^{\dagger}$ & $(\$ M)$ \\
\hline New York & 1 & 328 & 2 & 755 & 3 & 19.0 & 5 & 83.0 \\
\hline New Jersey & 2 & 267 & 8 & 332 & 9 & 8.4 & 3 & 89.5 \\
\hline California & 3 & 230 & 1 & 1229 & 1 & 33.9 & 1 & 275.0 \\
\hline Texas & 4 & 199 & 3 & 687 & 2 & 20.9 & 6 & 80.0 \\
\hline Massachusetts & 5 & 136 & 11 & 263 & 13 & 6.3 & 2 & 130.0 \\
\hline Indiana & 6 & 120 & 15 & 182 & 14 & 6.1 & $\mathrm{~N} / \mathrm{A}$ & $2.0^{* * * *}$ \\
\hline Illinois & 7 & 109 & 4 & 446 & 5 & 12.4 & 18 & 3.0 \\
\hline Florida & 8 & 106 & 5 & 443 & 4 & 16.0 & 8 & $59.5^{\star \star \star \star \star}$ \\
\hline Ohio & 9 & 103 & 7 & 362 & 7 & 11.4 & 11 & 15.0 \\
\hline Pennsylvania & 10 & 75 & 6 & 383 & 6 & 12.3 & 14 & 11.0 \\
\hline
\end{tabular}

${ }^{\dagger}$ Ranking amoung the 50 U.S. states; $1=$ highest, $50=$ lowest.

Sources:

* Bureau of Economic Analysis. Regional Accounts Data: Gross State Product Data.

** U.S. Census Bureau. Census 2000 PHC-T-2. Table 1. States Ranked by Population: 2000

*** ACEEE. Summary Table of Public Benefit Programs and Electric Utility Restructuring.

**** Energy Information Administration. Annual Electric Utility Data - ElA-861 Data File.

***** Public Benefits Technical Advisory Committee: Florida Energy 2020 Study Commission.

Reliable, Sustainable, and Affordable: Maintaining Public Benefits in Florida's Electric System.

U.S. ESCOs also reported projects with costs of approximately $\$ 195 \mathrm{M}$ (7\% of total costs in our sample) in Canada, primarily in the province of Ontario.

\subsection{Market Segments}

We designated fourteen market segments - six institutional and eight in the private sector - and requested that ESCOs classify each project in one of these categories:

Institutional

- Kindergarten through 12th-grade (K-12) schools (SC)

- State/local government (GO)

- University/colleges (UC)

- Federal government (FG)

- Health/hospitals $(\mathrm{HH})$

- Public housing (PH)

Private

- Hotel/hospitality (HO)

- Offices, commercial - leased (OL)

- Offices, commercial - owner-occupied (OO)

- Retail, single site (RS)

- Retail, multi-site (RM)

- Industrial (IN)

- Residential (RE)

- Other (OT) 
ESCOs have been most successful in developing projects in the institutional sector (see Figure 3-2). Of the 1473 projects coded by market segment, $74 \%$ are from institutional customers (local, state or federal governments, K-12 schools, universities, and health services). K-12 schools were the most active market (30\%), followed by state/local governments (14\%), health/hospitals $(12 \%)$, university/college $(9 \%)$, federal government $(6 \%)$, and public housing $(3 \%)$. The private sector projects comprise $26 \%$ of our database, with $16 \%$ commercial, $7 \%$ industrial, and only $1 \%$ residential projects. ${ }^{8}$ Two percent of the projects were designated as "other."

In order to examine the impacts of electricity industry restructuring on the ESCO industry, projects were also grouped into two time periods based on the date of completion: pre 1996 (all projects up to and including 1995) and 1996 to present.

The relative importance of institutional sector clients to ESCOs has been increasing in recent years. As can be seen in Figure 3-3, private sector projects accounted for a greater share of total projects prior to 1996. After 1995, the private sector share of total projects dropped from $33 \%$ to only $25 \%$. The relative share of the individual market segments within the private sector did not change dramatically during this time period. The market share for K-12 schools increased significantly ( $22 \%$ to $33 \%$ ). The share of state/local government and federal government projects also increased while health/hospital and university/college projects decreased.

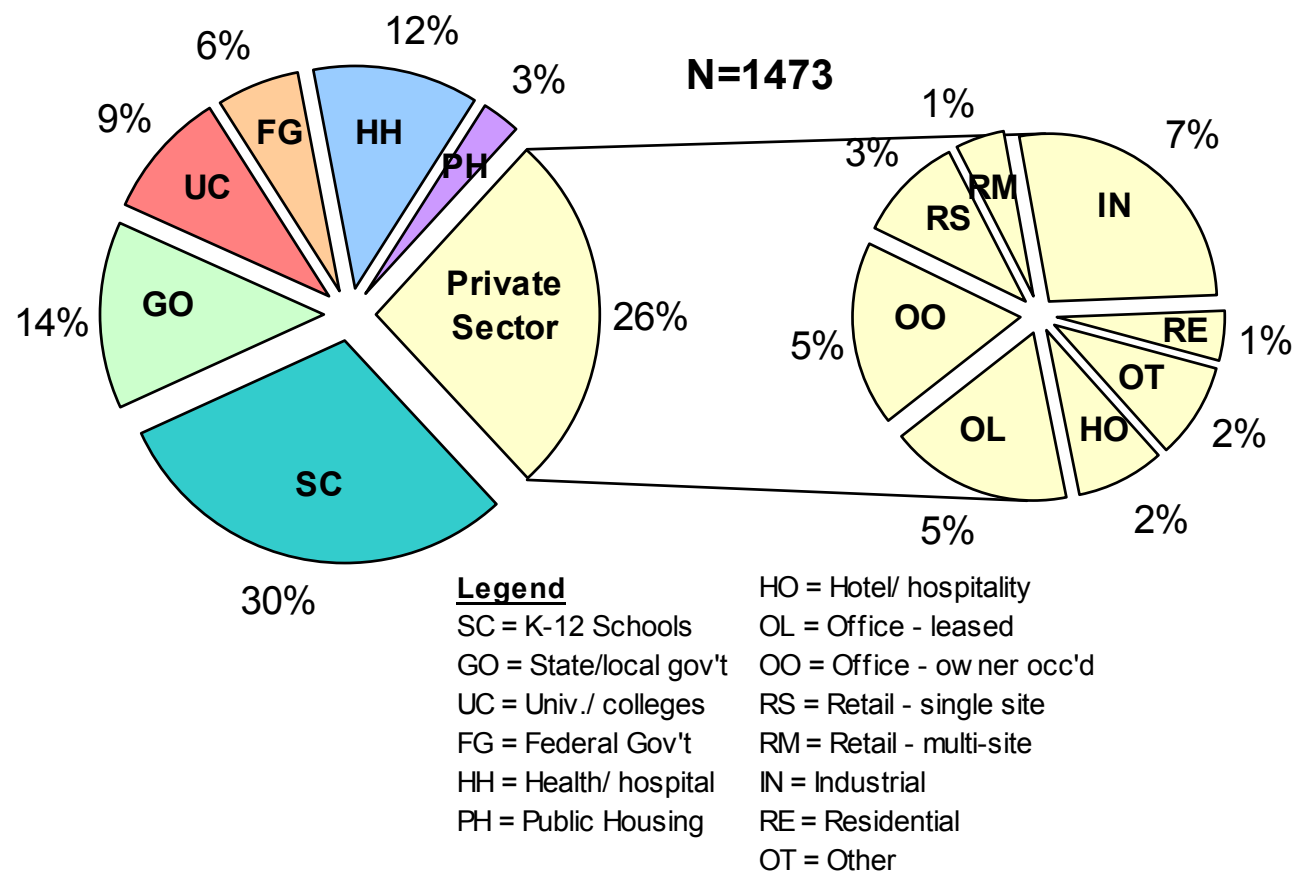

Figure 3-2. ESCO Projects Primarily Target Institutional Market Sectors

\footnotetext{
${ }^{8}$ Residential projects are primarily private, multi-family dwellings. For the purposes of the database, public housing is captured in the institutional sector.
} 


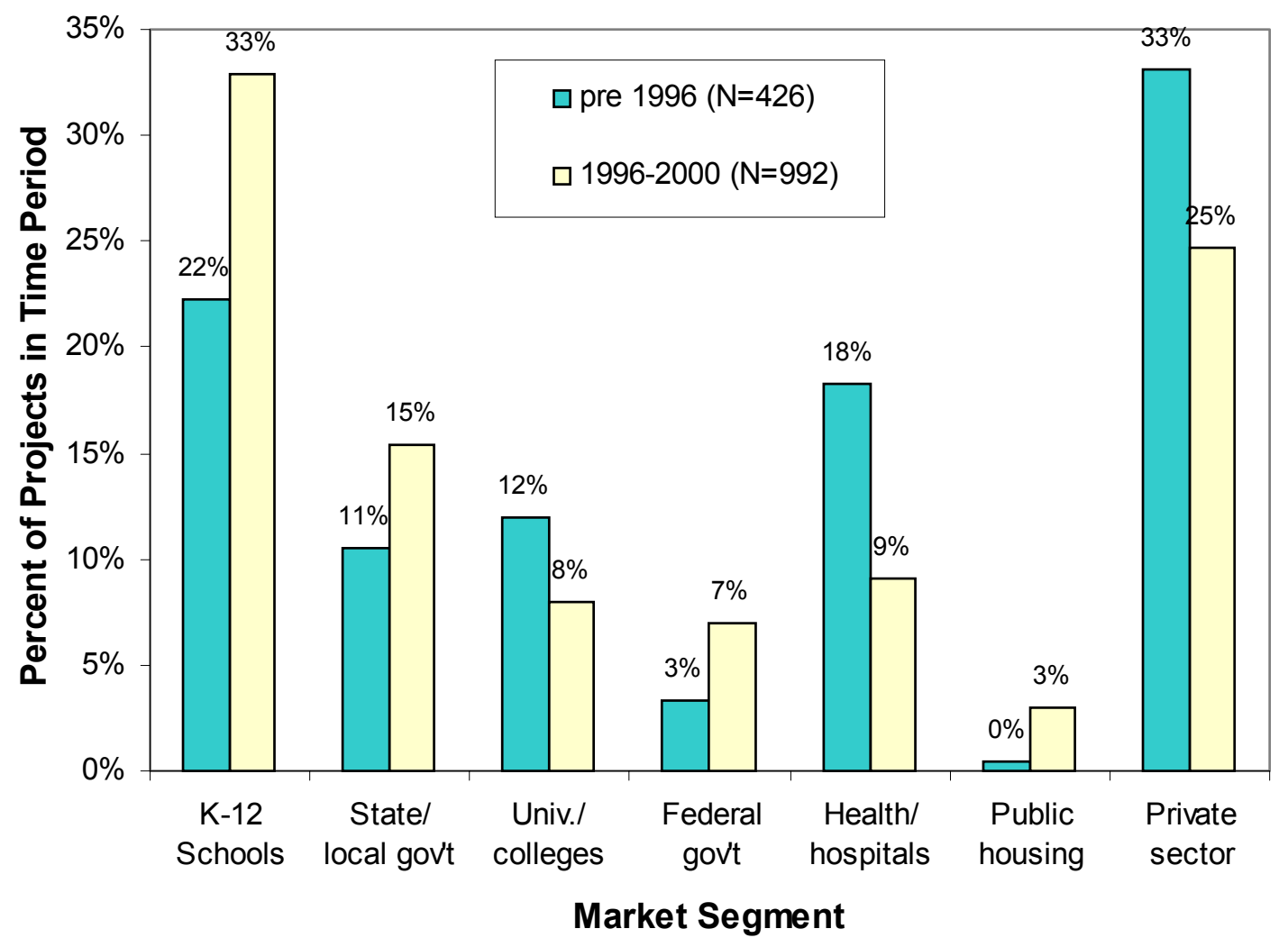

Figure 3-3. Evolution of ESCO Market Activity

We believe that the relative market share for ESCO activity in the institutional sector based on our project sample (73\%) represents an upper bound on actual ESCO institutional market activity for two reasons. First, ESCOs more readily provide information on public sector projects. Second, the database includes 259 projects that were provided directly by public sector sources.

\subsection{Project Facility Characteristics}

We collected information on facility characteristics for each project, including floor area, number of buildings, and type of facility. For the $46 \%$ of projects that reported floor area, energy conservation retrofits were performed on $661 \mathrm{M} \mathrm{ft}^{2}$ of buildings, the bulk of which are institutional facilities. If average floor area per project is extrapolated over all projects in the database, our sample includes approximately $1.2 \mathrm{~B} \mathrm{ft}^{2}$ of retrofitted floor area. In reporting floor area, ESCOs were asked to include only the buildings at a site that either received or were included in the retrofit project. ESCOs reported that $\sim 12,600$ buildings were retrofitted in the 822 projects that included this information.

ESCOs were also asked to classify the facilities that were retrofitted into one of 13 categories (see Table 3-2). The majority of retrofit projects (65\%) were implemented in educational facilities, offices, and healthcare facilities. 
Table 3-2. Project Facility Types and Frequency in Database

\begin{tabular}{|l|c|c|}
\hline \multicolumn{1}{|c|}{ Facility Type } & $\begin{array}{c}\text { No. of } \\
\text { Projects } \\
\text { (N=1489) }\end{array}$ & Percent \\
\hline Education (e.g., K-12 \& college classrooms) & 552 & $37 \%$ \\
Food Sales (e.g., grocery store) & 10 & $1 \%$ \\
Food Service (e.g., restaurant, cafeteria) & 19 & $1 \%$ \\
Health Care & 179 & $12 \%$ \\
Lodging (e.g., hotels, motels) & 13 & $1 \%$ \\
Mercantile and Service (e.g., retail) & 39 & $3 \%$ \\
Office (e.g., general office space) & 238 & $16 \%$ \\
Public Assembly (e.g., stadiums, auditoriums) & 29 & $2 \%$ \\
Public Order and Safety & 41 & $3 \%$ \\
Residential Housing & 53 & $4 \%$ \\
Warehouse & 22 & $1 \%$ \\
Wastewater Treatment Plant & 5 & $0 \%$ \\
Multiple & 86 & $6 \%$ \\
Other & 168 & $11 \%$ \\
\hline
\end{tabular}

Table 3-3 shows the distribution of floor area (and number of buildings) for projects in each of the 13 market segments. Projects with the highest median floor area values are at multi-site retail establishments, public housing, university/ colleges, and federal government facilities. In our sample, the median floor area of the 521 institutional sector projects is greater than the 156 private sector projects (i.e., 450,000 vs. 310,000 square feet). With the exception of health/hospitals, institutional projects usually encompass multiple buildings (median $=5$ ) whereas private sector projects, except multi-site retail as mentioned above, are usually single building projects.

Table 3-3. Market Segment Variation of Facility Size

\begin{tabular}{|c|c|c|c|c|c|c|c|c|c|c|c|c|}
\hline \multirow{3}{*}{ Market Segment } & \multirow{3}{*}{\begin{tabular}{|c|} 
No. of \\
Projects \\
( $\mathrm{N}=1473$ )
\end{tabular}} & \multicolumn{6}{|c|}{ Floor Area } & \multicolumn{5}{|c|}{ No. of Buildings } \\
\hline & & \multirow{2}{*}{$\mathrm{N}$} & \multirow{2}{*}{$\%$} & total & $25 \mathrm{va}$ & nedia & $75 \mathrm{val}$ & \multirow{2}{*}{$\mathrm{N}$} & \multirow{2}{*}{$\%$} & \multirow{2}{*}{$25 \mathrm{val}$} & \multirow{2}{*}{ median } & \multirow{2}{*}{$75 \mathrm{val}$} \\
\hline & & & & $\left(\right.$ million $\left.\mathrm{ft}^{2}\right)$ & \multicolumn{3}{|c|}{$\left(10,000 \mathrm{ft}^{2}\right)$} & & & & & \\
\hline K-12 Schools & 439 & 219 & $50 \%$ & 148 & 22 & 38 & 82 & 234 & $53 \%$ & 3 & 6 & 11 \\
\hline State/local government & 200 & 107 & $54 \%$ & 79 & 13 & 33 & 83 & 127 & $64 \%$ & 1 & 4 & 8 \\
\hline University/college & 139 & 66 & $47 \%$ & 95 & 49 & 71 & 200 & 73 & $53 \%$ & 5 & 18 & 33 \\
\hline Federal government & 85 & 56 & $66 \%$ & 86 & 35 & 69 & 144 & 46 & $54 \%$ & 1 & 12 & 33 \\
\hline Health/hospital & 178 & 65 & $37 \%$ & 92 & 23 & 45 & 76 & 77 & $43 \%$ & 1 & 1 & 3 \\
\hline Public Housing & 39 & 8 & $21 \%$ & 11 & 54 & 150 & 200 & 17 & $44 \%$ & 4 & 8 & 13 \\
\hline Hotel/hospitality & 33 & 18 & $55 \%$ & 6 & 4 & 9 & 30 & 22 & $67 \%$ & 1 & 1 & 1 \\
\hline Office, commercial - leased & 69 & 43 & $62 \%$ & 22 & 14 & 34 & 70 & 50 & $72 \%$ & 1 & 1 & 2 \\
\hline Office, commercial - owner-occupied & 71 & 29 & $41 \%$ & 23 & 34 & 47 & 120 & 52 & $73 \%$ & 1 & 1 & 1 \\
\hline Retail - single site & 40 & 8 & $20 \%$ & 3 & 9 & 11 & 24 & 30 & $75 \%$ & 1 & 1 & 1 \\
\hline Retail - multi-site & 18 & 6 & $33 \%$ & 38 & 40 & 195 & 331 & 13 & $72 \%$ & 1 & 15 & 49 \\
\hline Industrial & 107 & 32 & $30 \%$ & 47 & 13 & 33 & 46 & 52 & $49 \%$ & 1 & 1 & 1 \\
\hline Residential & 19 & 7 & $37 \%$ & 2 & 17 & 24 & 28 & 9 & $47 \%$ & 1 & 2 & 5 \\
\hline Other & 36 & 13 & $36 \%$ & 3 & 8 & 16 & 33 & 20 & $56 \%$ & 1 & 1 & 4 \\
\hline Institutional Sector & 1,080 & 521 & $48 \%$ & 512 & 24 & 45 & 95 & 574 & $53 \%$ & 1 & 5 & 13 \\
\hline Private Sector & 393 & 156 & $40 \%$ & 143 & 12 & 31 & 65 & 248 & $63 \%$ & 1 & 1 & 1 \\
\hline
\end{tabular}




\subsection{Installed Measures}

\subsubsection{Penetration Rates for Various Types of Energy Conservation Measures (ECMs)}

ESCOs were also asked to report information on energy conservation measures (ECMs) and other measures or strategies that were installed at each project. In early rounds of the accreditation process, ESCOs were asked to list ECMs in response to an open-ended question. These individual measures were then coded into the appropriate category with standardized nomenclature. Since 2000, ESCOs and state agencies have reported individual measures from the list shown in Appendix A.

For analysis purposes, we then aggregated individual ECMs into 11 "measure categories" which include measures in four main end uses (lighting, comfort conditioning, water heating, and refrigeration), six categories that include other and miscellaneous measures (power supply, motors/drives, plumbing products \& fittings, industrial process improvements, miscellaneous equipment \& systems, and other measures/strategies) and non-energy facility improvements. ${ }^{9}$ Measures installed by ESCOs are reported in these broader categories so that the breadth and depth of energy-efficiency improvements among projects and across market sectors can be more readily compared.

\section{Table 3-4. Deployment of Energy-Efficiency Technologies and Strategies}

\begin{tabular}{|l|cc|cc|cc|}
\hline \multirow{2}{*}{ Measure Category } & \multicolumn{2}{|c|}{$\begin{array}{c}\text { Entire Database } \\
\text { (N=1379) }\end{array}$} & $\begin{array}{c}\text { Institutional Sector } \\
\text { (N=1008) }\end{array}$ & \multicolumn{2}{c|}{$\begin{array}{c}\text { Private Sector } \\
\text { (N=359) }\end{array}$} \\
\cline { 2 - 7 } & $\mathrm{N}$ & $\%$ & $\mathrm{~N}$ & $\%$ & $\mathrm{~N}$ & $\%$ \\
\hline Lighting & 1134 & $82 \%$ & 859 & $85 \%$ & 264 & $74 \%$ \\
Comfort Conditioning & 936 & $68 \%$ & 768 & $76 \%$ & 163 & $45 \%$ \\
Motors/drives & 320 & $23 \%$ & 254 & $25 \%$ & 64 & $18 \%$ \\
Water heaters & 117 & $8 \%$ & 101 & $10 \%$ & 15 & $4 \%$ \\
Non-energy improvements & 46 & $3 \%$ & 46 & $5 \%$ & 0 & $0 \%$ \\
Power supply & 81 & $6 \%$ & 63 & $6 \%$ & 18 & $5 \%$ \\
Refrigeration & 26 & $2 \%$ & 15 & $1 \%$ & 11 & $3 \%$ \\
Miscellaneous equipment \& systems & 41 & $3 \%$ & 37 & $4 \%$ & 4 & $1 \%$ \\
Industrial process improvements & 23 & $2 \%$ & 8 & $1 \%$ & 15 & $4 \%$ \\
Other measures/strategies & 287 & $21 \%$ & 246 & $24 \%$ & 41 & $11 \%$ \\
Plumbing products \& fittings & 132 & $10 \%$ & 119 & $12 \%$ & 13 & $4 \%$ \\
\hline
\end{tabular}

Table 3-4 summarizes the penetration rate of our measure categories for projects in the entire database and disaggregated for institutional and private sector projects. ${ }^{10}$ About $82 \%$ of the projects installed high-efficiency lighting systems, lighting equipment or lighting controls. About $68 \%$ of the projects installed various types of comfort conditioning measures which include central plant retrofits, HVAC equipment replacement, HVAC distribution system retrofits, ventilation, controls, and building envelope measures (e.g., insulation, high-efficiency windows), while $23 \%$ of the projects included motor retrofits or replacements, or installed variable speed drives.

\footnotetext{
${ }^{9}$ Examples of other strategies include staff training, metering and billing systems, and rate analysis/change.

${ }^{10}$ Appendix A lists the frequency with which individual measures were reported.
} 
The most popular measures (lighting, comfort conditioning, motors/drives) are ranked similarly in both institutional and private sectors, but there are some interesting differences in the rate of penetration of various measure categories. For example, comfort conditioning measures are more popular in institutional than private sector projects ( $76 \%$ vs. $45 \%$ ). Not surprisingly, industrial process improvements have somewhat higher penetration rates in private sector than institutional sector projects ( $4 \%$ vs. $1 \%$ ). Non-energy improvements are only found in the institutional sector. Of the institutional projects, $5 \%$ report non-energy improvements, primarily roof replacement/repair. Asbestos abatement and new ceilings are also common. K-12 schools account for $85 \%$ of these non-energy improvements, which are reported for $9 \%$ of all K- 12 projects. Differences in penetration rates of measure categories between institutional and private sectors may also illustrate somewhat different customer motivations and goals. For example, in the institutional sector, the stream of savings generated by a performance-contracting project often can help pay for capital renovations such as new roofs or new equipment that otherwise might not be funded.

Projects in the database typically involve installation of multiple measures: on average 1.9 measure categories per project (see Table 3-5). The saturation of measures is somewhat lower in the private sector than institutional sector markets. There is also generally a higher diversity of measure category retrofits in the institutional sector projects.

Table 3-5. Intensity of Installed End Use Retrofits by Market Segment

\begin{tabular}{|l|c|c|}
\hline Market Segment & N & $\begin{array}{c}\text { Average No. of } \\
\text { Measure Categories } \\
\text { per project }\end{array}$ \\
\hline Institutional sector: & 1008 & 2.2 \\
\hline K-12 Schools & 416 & 2.3 \\
State/local government & 181 & 1.9 \\
University/college & 125 & 2.1 \\
Federal government & 82 & 2.0 \\
Health/hospital & 165 & 1.8 \\
Public Housing & 39 & 2.4 \\
\hline Private sector & 355 & 1.6 \\
\hline Entire Database & $\mathbf{1 3 7 9}$ & $\mathbf{1 . 9}$ \\
\hline
\end{tabular}

\subsubsection{Retrofit Strategy}

Projects were also classified into one of three broad retrofit strategies based on the types of measures installed: Lighting Only (LO) measures, Lighting \& Non-lighting (LNL) measures, and Non-lighting Only (NLO) measures. Because very few projects report single measures, these three strategies serve as a proxy to analyze trends among projects that target different end uses. The percent of projects employing each strategy are:

- $24 \% \mathrm{LO}$

- $58 \% \mathrm{LNL}$

- $18 \% \mathrm{NLO}(<1 \%$ of these projects reported single measures). 
LO retrofits are quite common in private sector projects (43\%). In contrast, institutional sector projects more often include comfort-conditioning measures with lighting. This is reported in two-thirds of institutional projects and in less than one-third of private sector projects. ${ }^{11}$

\subsection{Project Costs}

ESCOs were requested to provide information on project costs, which was defined in terms of the costs that would typically be included in a "turnkey" energy-efficiency services project:

The cost to develop and construct the project including all development, engineering, installation, and construction financing costs as of the date of acceptance by customer (excludes future financing costs and ongoing project service costs such as maintenance and monitoring).

About $16 \%$ of the projects included the financing costs related to servicing of long-term debt financing. Based on the sample of projects that supplied cost both with and without financing $(\mathrm{N}=97)$, we estimate that future financing costs increase the "turnkey" project costs by about $21 \%{ }^{12}$. The 1426 projects ( $96 \%$ of the database) that included information on project costs represent a cumulative investment of $\$ 2.6 \mathrm{~B}$ in energy-efficiency improvements.

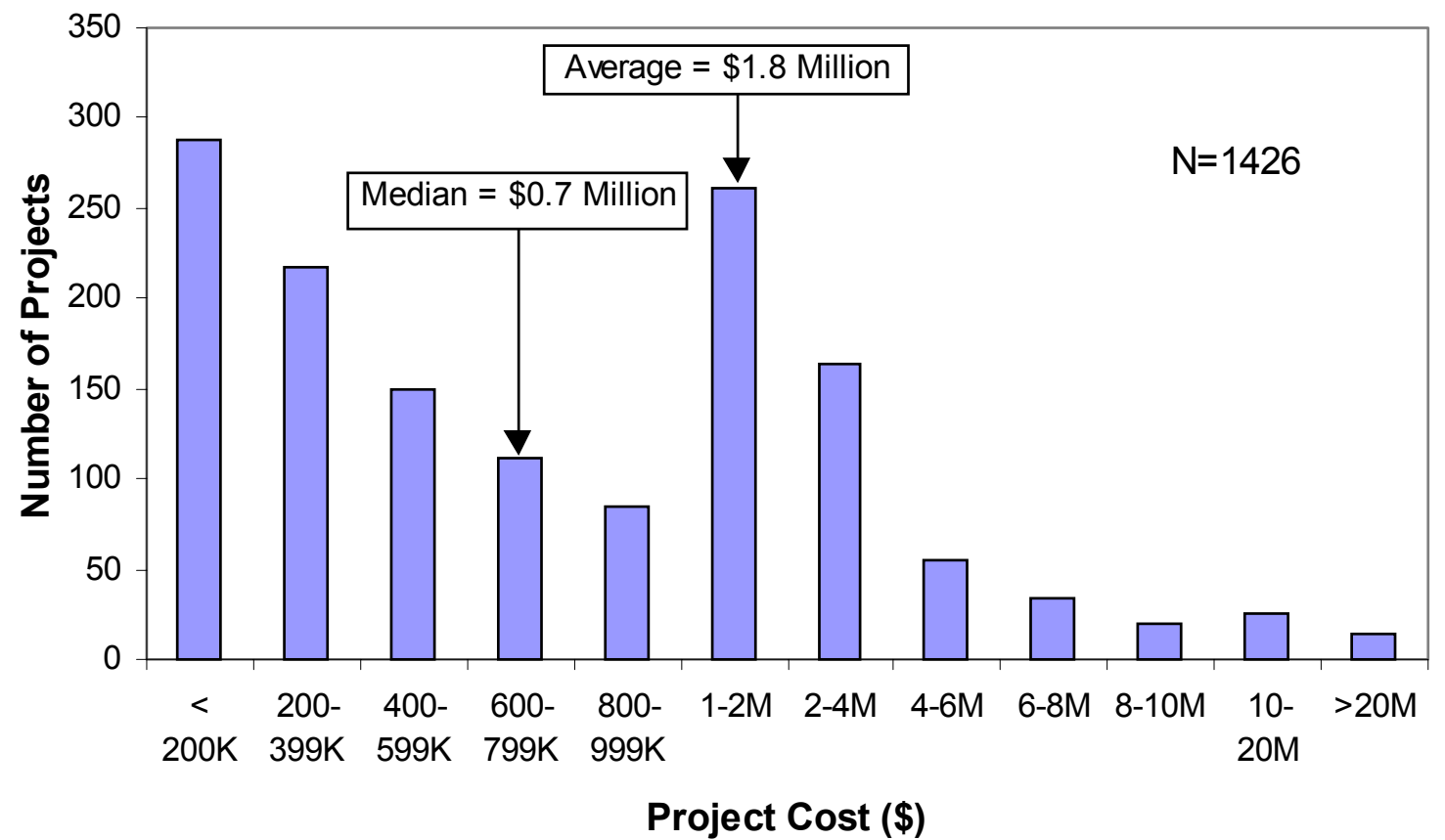

Figure 3-4. Range in Project Costs

\footnotetext{
${ }^{11}$ Appendix B contains a market segment detail version of Table 3-4.

${ }^{12}$ For projects that provided costs both including and excluding financing, we used costs excluding financing in our economic analysis.
} 
Figure 3-4 displays the range of project costs. Median and average project costs are $\$ 0.7 \mathrm{M}$ and $\$ 1.8 \mathrm{M}$ respectively over the entire sample. Note the tremendous variation in project costs in the sample with $\sim 280$ projects costing $<\$ 200,000$ and $10-15$ projects costing more than $\$ 20 \mathrm{M}$.

These projects were installed over the last 18 years, beginning in 1982. However, our sample of project data are quite spotty during the 1980s; about two-thirds of total costs are represented by projects that have been completed since 1996, reflecting both our intensified data collection efforts and the growth of the ESCO industry in recent years.

\subsubsection{Project Costs by Market Segment}

Figure 3-5 shows the median and inter-quartile range in project costs in each market segment. Median project costs are higher in K-12 schools, university/ colleges, and public housing compared to other market segments $(\$ 1.2-1.8 \mathrm{M}$ vs. \$0.3-0.9M). Costs are also higher in each institutional market segment than in the private sector. In aggregate, median project costs in the institutional sector are three times higher than the median cost of private sector projects $(\$ 0.9 \mathrm{M}$ vs. $\$ 0.3 \mathrm{M})$.

Figure 3-5 also shows that project costs within market segments are highly variable. For the middle $50 \%$ of projects (inter-quartile range), costs typically vary by a factor of three.

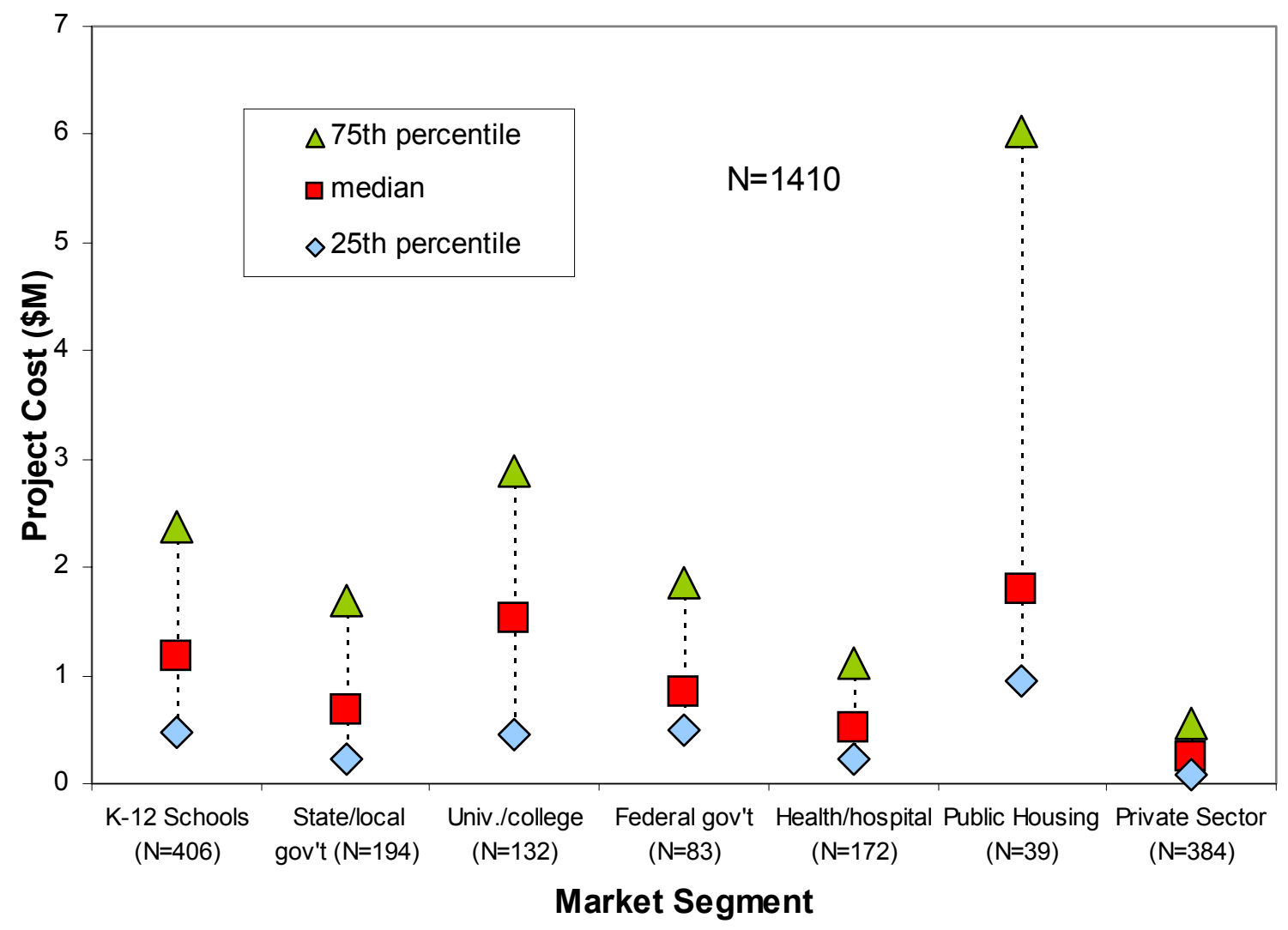

Figure 3-5. Project Cost by Market Segment 


\subsubsection{Factors That Contribute to Variation in Project Costs}

A number of factors possibly explain the large variation in costs among projects in the same market segment: facility size (floor area), differences in the scope, type and comprehensiveness of the retrofit measures/strategies (e.g., number of ECMs, end uses targeted, capitalintensiveness of measures), inclusion of non-energy improvements, varying development practices of ESCOs (e.g., multiple phases vs. single phase projects), and differences in ESCO reporting practices. We conducted exploratory analysis of several of these factors to better understand variation in project costs within market segments.

We normalized project costs by floor area where possible. ${ }^{13}$ Median project investment ranges between $\$ 1-3 / \mathrm{ft}^{2}$ in each market segment (see Figure 3-6). Median project investment is still highest in the K-12 School projects $\left(\$ 2.90 / \mathrm{ft}^{2}\right)$, followed closely by state/local government projects $\left(\$ 2.80 / \mathrm{ft}^{2}\right)$. Median investment relative to other market segments decreases for university/colleges and increases for health/hospitals when costs are normalized by floor area (compare Figure 3-5 and 3-6). Median values for cost $/ \mathrm{ft}^{2}$ are higher for institutional than for private sector projects $\left(\$ 2.50\right.$ vs. $\left.\$ 1.40 / \mathrm{ft}^{2}\right)$. For all projects $(\mathrm{N}=678)$, the median investment $/ \mathrm{ft}^{2}$ is $\$ 2.30 / \mathrm{ft}^{2}$. Normalizing for floor area reduces the inter-quartile range $\left(25^{\text {th }}-75^{\text {th }}\right.$ percentile values $)$ within each market segment: project cost $/ \mathrm{ft}^{2}$ varies by factors of 3-6, while project costs vary by factors of 4 to 7 .

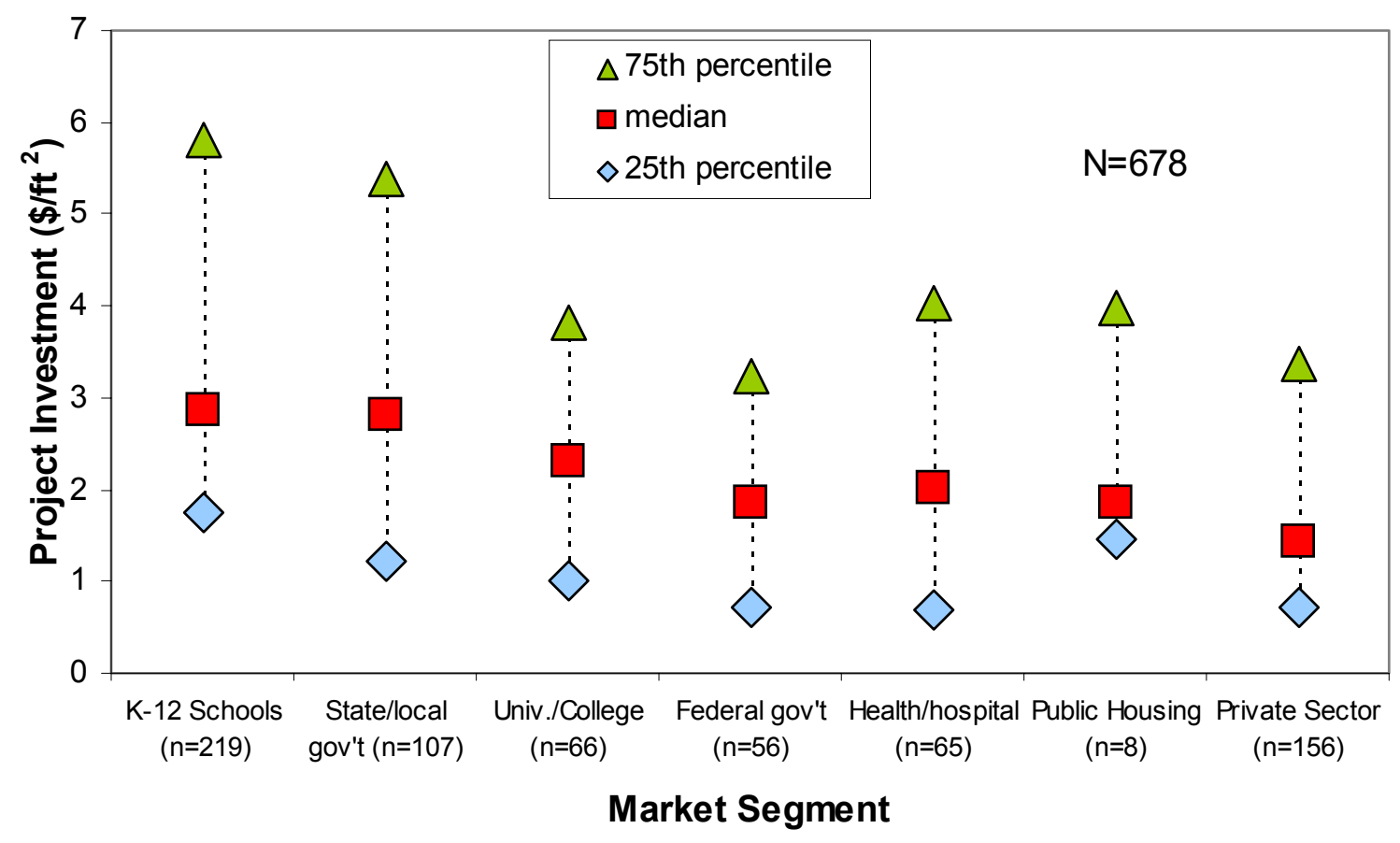

Figure 3-6. Project Cost Normalized by Floor Area

We also compared project costs by retrofit strategy and found that differences in the type of measures installed in institutional and private sector projects appear to contribute to differences

\footnotetext{
${ }^{13}$ ESCOs were asked to report floor area of conditioned space that was retrofitted; data quality and availability varies among ESCOs.
} 
in median costs. Table 3-6 shows average, median, $25^{\text {th }}$ and $75^{\text {th }}$ percentiles in project cost $/ \mathrm{ft}^{2}$ for institutional and private sector projects, classified by retrofit strategy (LO, LNL, NLO). For NLO projects, median project costs are significantly greater for institutional projects than they are for private sector projects $\left(\$ 2.73 / \mathrm{ft}^{2}\right.$ vs. $\left.\$ 1.17 / \mathrm{ft}^{2}\right)$. This suggests that the type and capitalintensiveness of NLO projects are quite different in institutional and private sector markets (e.g., more low-cost industrial process type retrofits in private sector non-lighting only projects). This difference in the relative cost of NLO projects largely helps to explain why median project costs are higher for institutional than private sector projects. Median project costs are comparable for $\mathrm{LO}$ and LNL projects.

Table 3-6. Project Investment by Retrofit Strategy: Institutional and Private Sectors

\begin{tabular}{|c|c|c|c|c|c|c|c|c|c|c|}
\hline \multirow{3}{*}{ Retrofit Strategy } & \multicolumn{10}{|c|}{ Project Investment $\left(\$ / \mathrm{ft}^{2}\right)$} \\
\hline & \multicolumn{5}{|c|}{ Institutional Sector } & \multicolumn{5}{|c|}{$\begin{array}{l}\text { Private Sector } \\
\end{array}$} \\
\hline & $\mathrm{N}$ & |average & $25 \mathrm{val}$ & median & $75 \mathrm{val}$ & $\mathrm{N}$ & average & $25 \mathrm{val}$ & median & $75 \mathrm{val}$ \\
\hline igh & 76 & 1.39 & 0.58 & 0.78 & 1.77 & 58 & 2.19 & 0.57 & 0.81 & 1.44 \\
\hline & 360 & 5.19 & 1.75 & 2.93 & 5.78 & 56 & 4.58 & 1.58 & 3.17 & 5.34 \\
\hline Non-Lighting Only & 54 & 4.24 & 0.97 & 2.73 & 5.40 & 24 & 1.99 & 0.81 & 1.17 & 2.42 \\
\hline
\end{tabular}

In Table 3-7, we examine the project investment cost per energy saved (\$/million Btu) over the project's economic lifetime, accounting for different retrofit strategies. LNL projects, though most expensive in terms of project investment intensity, were actually the best deal in terms of leveraging lifetime energy savings for a given investment (\$81/MBtu saved). Figure 3-7 indicates that the private sector median cost per energy saved is greater than for the institutional market sector (\$125/MBtu vs. \$53-102/MBtu). ${ }^{14}$

Table 3-7. Project Investment / Energy Saved by Retrofit Strategy

\begin{tabular}{|l|c|c|c|c|c|}
\hline \multirow{2}{*}{ Retrofit Strategy } & \multicolumn{5}{|c|}{$\begin{array}{c}\text { Investment / Energy Saved } \\
\text { (\$/million BTU) }\end{array}$} \\
& $\mathrm{N}$ & average & 25 val & median & 75 val \\
\hline Lighting Only & 227 & 127 & 66 & 98 & 166 \\
Lighting \& Non-Lighting & 377 & 163 & 41 & 81 & 135 \\
Non-Lighting Only & 83 & 195 & 50 & 101 & 204 \\
\hline
\end{tabular}

\footnotetext{
${ }^{14}$ The $\$ 75 /$ MBtu is the median value of all institutional market segments.
} 


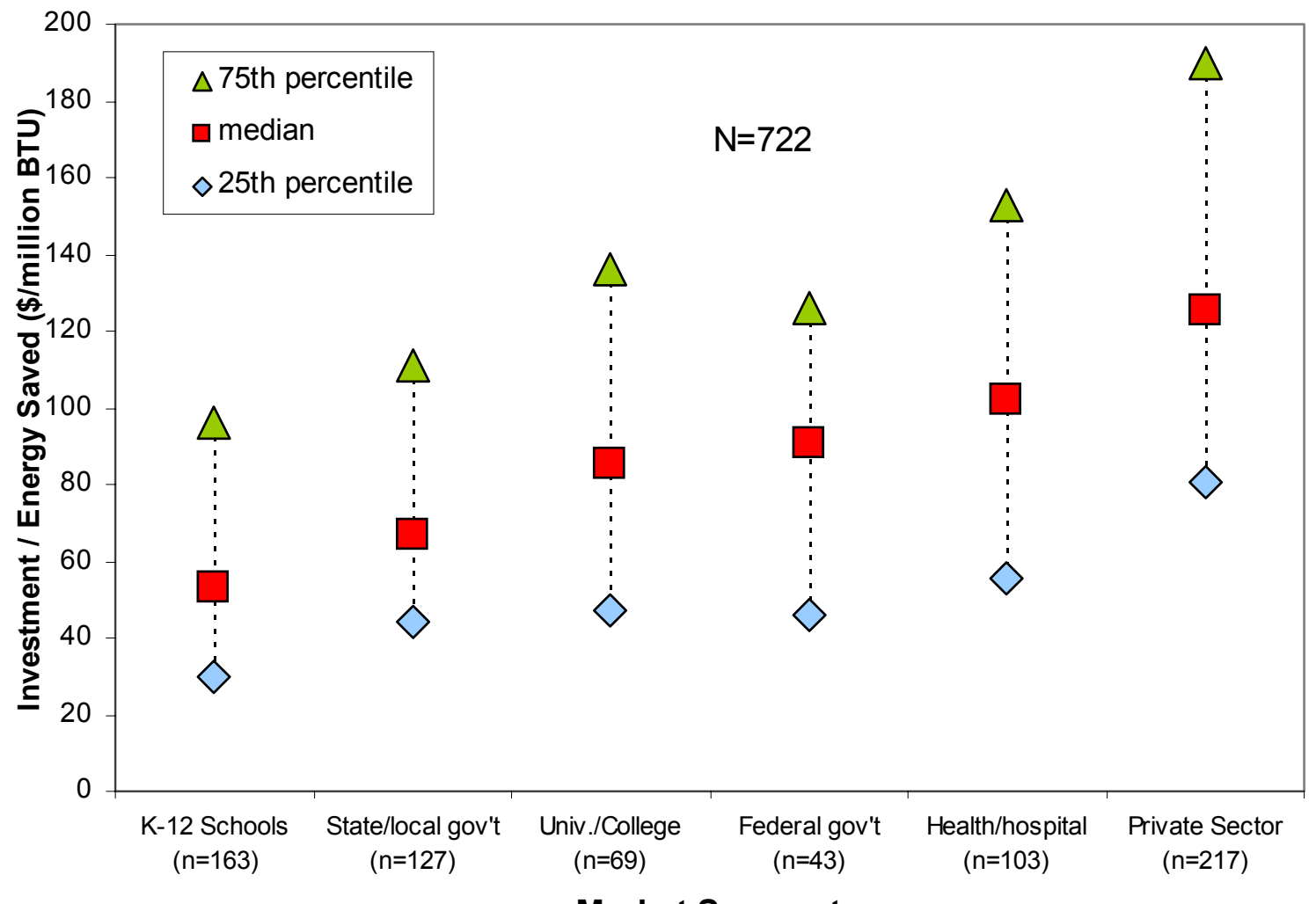

Market Segment

Figure 3-7. Project Cost per Lifetime Energy Savings

\subsection{Types of Contract Agreement and Term}

\subsubsection{Performance-Contracting vs. Non-Performance-Contracting Arrangements}

Over the last decade, there has been an evolution in the types of contract agreements utilized by ESCOs and their customers. ESCOs and state agencies were asked to characterize the type of contract agreement for each project using the following typology and definitions:

Performance-based Contracts:

Guaranteed savings

Guaranteed payout term Asset ownership/chauffage

\section{Shared savings}

Pay-from-savings
ESCO guarantees minimum savings to customer.

ESCO retains savings until "paid out" or for specified period. ESCO sells end use services to customer at specified prices over contract term.

Customer and ESCO share benefits of investment on a predetermined basis over contract term .

Percentage of customer's savings applied against investment.

Non Performance-based Contracts: 


\section{Design/build}

Fee-for-service

Fixed price
ESCO develops project on turnkey basis; paid for services provided, may include some price cap linked to original proposal.

ESCO is reimbursed for various services provided during project development.

Cost of project to customer capped by ESCO at fixed price.

In this typology, the key distinction between performance- and non performance-based contracting approaches is that, in performance-based contracts, an ESCOs compensation for a project is linked in some fashion to the project's ongoing performance results (e.g., energy and cost savings). In contrast, in the various types of non-performance based contracts, the ESCO receives the turnkey project price upon customer acceptance of the project.

Among ESCOs, the market share of performance-contracting projects has decreased significantly since 1996 (see Figure 3-8). Non-performance based contracts, primarily design/build, have increased in market share from $8 \%$ for the period prior to 1996 to $24 \%$ since 1996 . This trend likely understates the shift away from performance-contracting arrangements in the energyefficiency services market overall.

Of those projects utilizing a performance-based contract, guaranteed savings is by far the most common agreement type, comprising $86 \%$ of performance-based projects. Shared savings contracts are next most frequent, although this agreement type was more common in earlier projects, dropping from $27 \%$ of database projects pre- 1996 to $3 \%$ of reported projects post- 1995 .

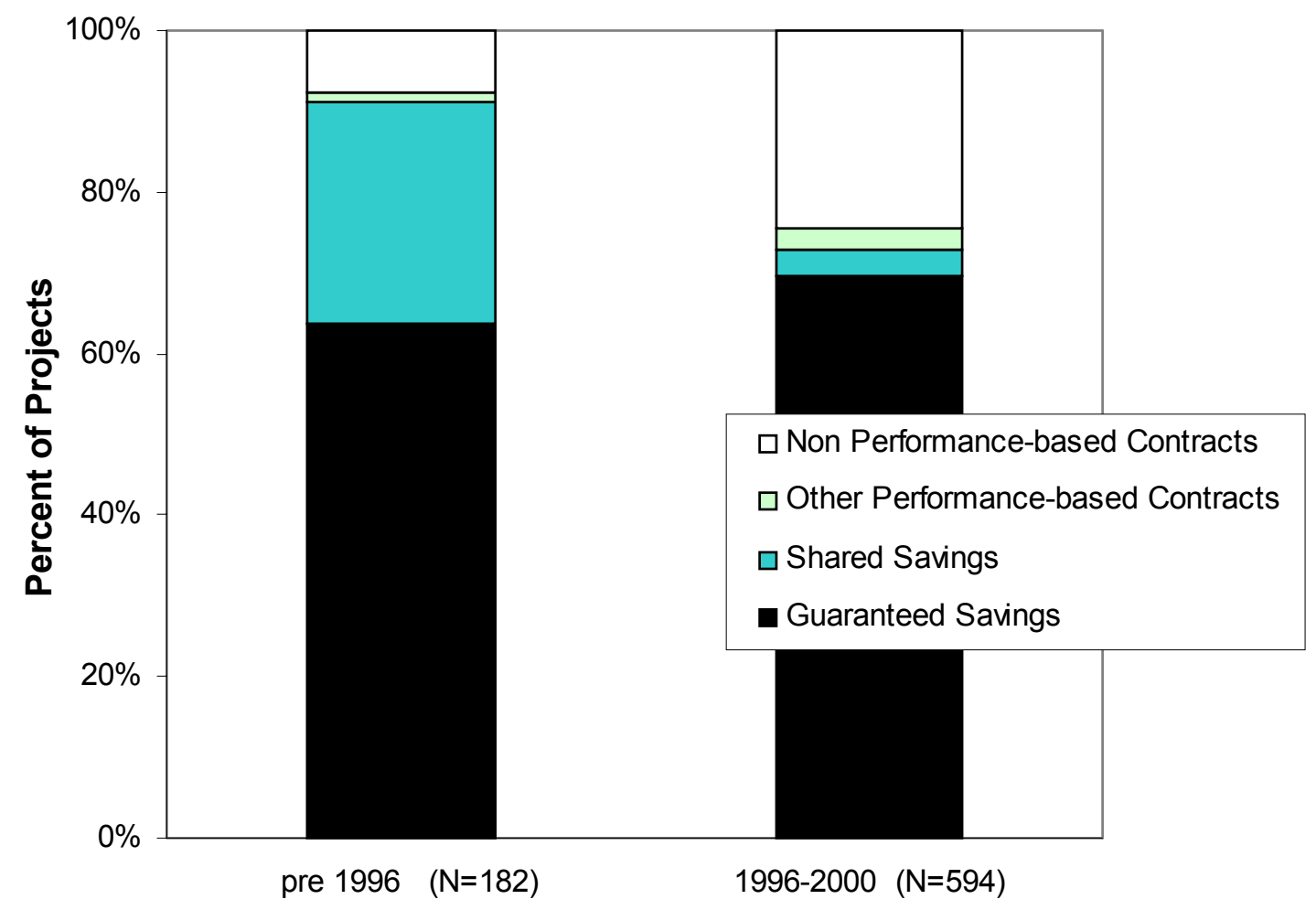

Time Period 
Figure 3-8. Performance Contracting is a Decreasing Share of ESCO Business

The 621 projects that reported performance-contracting arrangements typically had higher project costs than the 160 projects that reported non-performance based contracts: median project investment was $\$ 1.0 \mathrm{M}$ vs. $\$ 0.5 \mathrm{M}$ (see Table 3-8). This data suggests that ESCOs in our sample tend to use design/build and fee-for-service contracting approaches in smaller projects.

Table 3-8. Project Costs by Type of Contract Agreement

\begin{tabular}{|l|c|c|c|c|c|}
\hline \multicolumn{1}{|c|}{ Project Agreement Type } & \multicolumn{5}{c|}{ Project Cost (\$M) } \\
& $\mathrm{N}$ & average & 25 val & median & 75 val \\
\hline Performance-based Contracts & $\mathbf{6 2 1}$ & $\mathbf{2 . 3}$ & $\mathbf{0 . 4}$ & $\mathbf{1 . 0}$ & $\mathbf{2 . 4}$ \\
Guaranteed savings & 533 & 2.5 & 0.5 & 1.2 & 2.5 \\
Guaranteed payout term & 3 & 2.4 & 1.6 & 1.7 & 2.8 \\
Asset ownership/chauffage & 1 & 5.0 & 5.0 & 5.0 & 5.0 \\
Shared savings & 69 & 1.2 & 0.2 & 0.3 & 0.8 \\
Pay-from-savings & 15 & 2.4 & 0.7 & 1.2 & 2.3 \\
\hline Non Performance-based Contracts & $\mathbf{1 6 0}$ & $\mathbf{1 . 6}$ & $\mathbf{0 . 2}$ & $\mathbf{0 . 5}$ & $\mathbf{1 . 2}$ \\
Design/build & 118 & 1.8 & 0.2 & 0.5 & 1.3 \\
Fee-for-service & 26 & 0.5 & 0.1 & 0.2 & 0.8 \\
Fixed price & 16 & 1.9 & 0.4 & 0.6 & 2.2 \\
\hline
\end{tabular}

\subsubsection{Contract Term}

Trends in contract term were also examined in order to assess customers' willingness to enter into long-term agreements over time. Other factors that can affect contract term include the types of measures selected for retrofit and project economics (e.g., payback time). In some cases, exogenous factors related to ratepayer-funded energy-efficiency program (REEP) design requirements may also influence contract term. In doing this analysis, we focused on a subset of 538 projects where information on contract duration was provided and where the project was not part of a performance-based REEP. ${ }^{15}$ Figure 3-9 compares contract length for projects completed prior to and since 1996. The figure depicts an aggregate of institutional and private sector projects. ${ }^{16}$ The relative frequency of contracts with mid-range terms ( 5 to 9 years) decreased markedly, down 14\% from pre-1996 levels, while short (less than 5 year) and longer (10 to 14 year) contracts have become more common. Contracts lasting more than 15 years occurred in $\sim 10 \%$ of projects in both time periods. The shift toward shorter-term contracts may be explained by the trend away from performance contracts toward design/build arrangements.

\footnotetext{
${ }^{15}$ We excluded projects that were linked to performance-based REEP programs - DSM bidding and SPC programs - because the program administrator (typically a utility) established the contract term in their agreement with the ESCO, who typically passed on that term in their agreement with individual customers. We wanted to understand trends in contracting practices in the private sector marketplace, without the influence of these programs.

${ }^{16}$ Contract term tends to be shorter in private sector projects than institutional sector projects.
} 


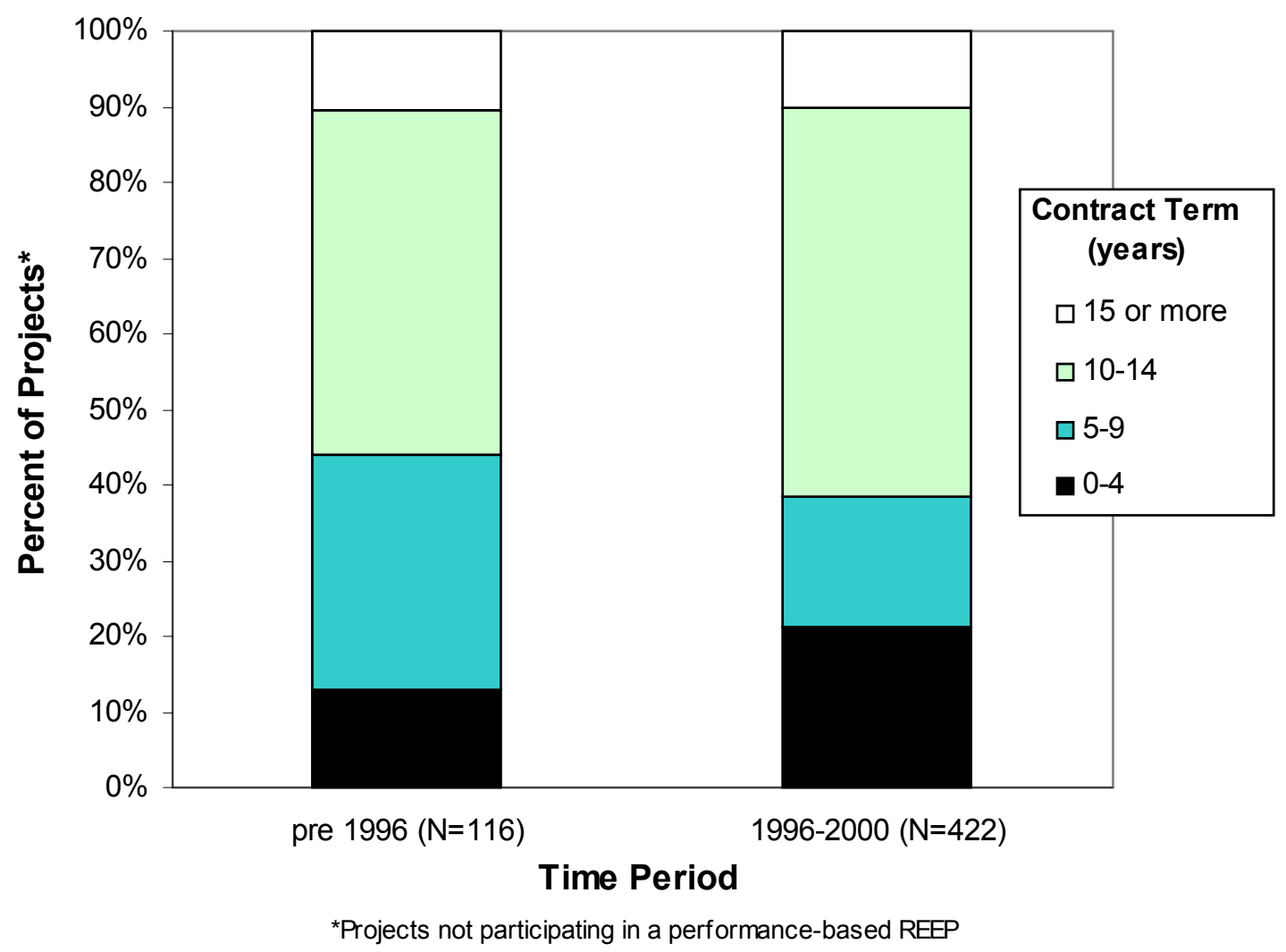

Figure 3-9. Shift in Average Contract Length of Projects 


\section{Energy Savings: What Energy Savings Have ESCOs Delivered for Typical Projects?}

\subsection{Summary}

- ESCOs were requested to report baseline consumption and predicted and actual, verified savings in energy and/or dollar terms for each project. Median energy savings are $15 \mathrm{kBtu} / \mathrm{ft}^{2}$ for the 437 projects ( $\sim 29 \%$ of projects in database) that provided necessary data. Reductions in electricity consumption accounted for over $80 \%$ of total energy savings on a site energy basis in this sample of projects.

- Median energy savings are highest for state/local government and health/hospital projects (18-19 kBtu/ $\left./ \mathrm{ft}^{2}\right)$ compared to $13-15 \mathrm{kBtu} / \mathrm{ft}^{2}$ for K-12 schools, university/college, federal government and private sector projects. After normalizing for floor area, energy savings typically vary by a factor of 3-5 for the middle $50 \%$ of projects within each market segment (i.e., inter-quartile range from $25^{\text {th }}$ to $75^{\text {th }}$ percentile).

- Lighting Only (LO) projects report median electricity savings of 47\% (with an inter-quartile range for the $25^{\text {th }}$ and $75^{\text {th }}$ percentile of $37 \%$ to $56 \%$ ) of the targeted equipment. These results suggest that ESCOs are achieving significant reductions in lighting energy consumption.

- The median electricity savings for Lighting \& Non-lighting (LNL) projects is $23 \%$ of the total electric bill baseline (quartile range from $17 \%$ to $32 \%$ ) and $18 \%$ (quartile range $8 \%$ to $41 \%$ ) for non-lighting projects. These empirical results give a sense of the extent to which ESCO projects are impacting total facility energy usage.

- The relative accuracy of ESCO savings estimates is of direct importance to customers, policymakers, and ESCOs. About $28 \%$ of the projects reported both actual and predicted savings. ESCO savings forecasts are more conservative for comprehensive retrofit projects, but actual savings in these projects are more likely to exceed their predictions. In LO projects, ESCO forecasts are closer to actual savings ( $\sim 50 \%$ of projects within $5 \%)$, but the customer is less likely to realize additional savings beyond what is predicted.

- We found that half (7) of the companies that provided both predicted and guaranteed savings data consistently guaranteed $100 \%$ of predicted energy savings to their customers. Six of the companies guaranteed between $50-100 \%$ of predicted savings, and two companies actually guaranteed less than $50 \%$ of predicted savings.

- Yearly savings data for more projects in the database is necessary to adequately evaluate the persistence of savings. Based on a small sample size $(\mathrm{N}=20)$, we found that the majority of projects $(72 \%)$ actually reported increased electricity savings over time (up to four years). 


\subsection{Methodology}

\subsubsection{Energy Savings: Actual, Predicted and Guaranteed}

ESCOs and state agencies were asked to report the following energy consumption and savings data, in either energy or dollar terms (or both) for each project:

(1) Baseline energy consumption - baseline energy use that was used as the basis for savings calculations or energy consumption prior to the retrofit;

(2) Predicted energy savings - the ESCO's predicted estimate of annual savings prior to installation of the project;

(3) Guaranteed energy savings - annual energy savings guaranteed by the ESCO as part of a performance contract; and

(4) Actual, verified energy savings - actual energy savings from the project which are verified by the ESCO after installation and which are reported either on a yearly basis or as a calculated annual average of actual energy savings achieved.

Because not all projects provided data on actual energy savings, we developed the following approach in analyzing energy savings for each project. Actual annual energy savings were used when available; average annual energy savings were calculated for projects with multiple years of post-installation data. If actual savings were not provided by the ESCO (or not available in the case of recently completed projects), then the ESCO's predicted estimate of energy savings was used for that project. In addition, approximately 335 projects only provided information on the estimated dollar value of energy savings (rather than savings in energy units). Rather than trying to estimate electricity and fuel savings for these projects, we included these projects only in our economic analysis of project benefits (Chapter 5). ${ }^{17}$

ESCOs were asked to provide baseline consumption and project savings data for electricity $(\mathrm{kWh})$, peak demand usage $(\mathrm{kW})$, and all other fuels for end uses affected by the retrofit (e.g., natural gas, fuel oil, coal). As shown in Figure 4-1, total energy savings for a project were then expressed in Btu, converting electricity usage based on site efficiency $(1 \mathrm{kWh}=3412 \mathrm{Btu})$. Water, O\&M and other non-energy savings were calculated separately and used in our economic analysis (see Chapter 5).

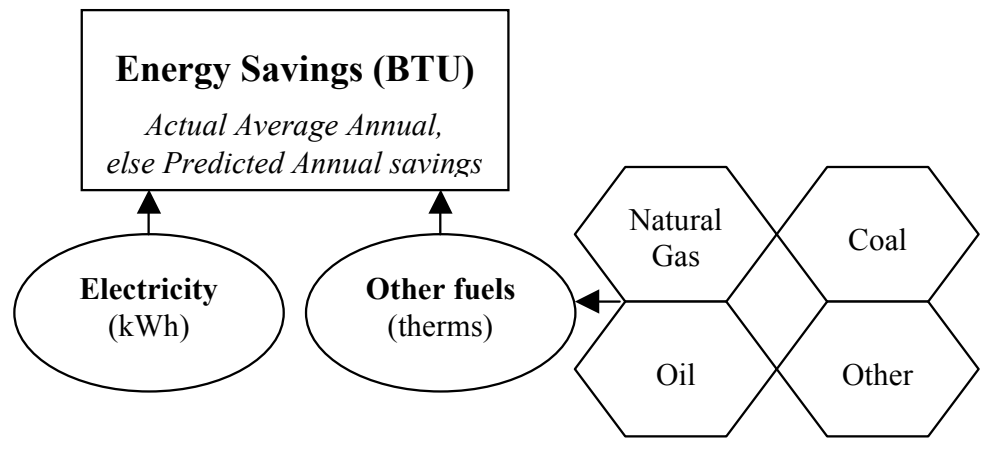

Figure 4-1. Collection and Aggregation of Project Energy Consumption and Savings Data

\footnotetext{
${ }^{17}$ In order to impute energy savings for projects that provided only annual dollar value of savings, we would have to impute assumed fuel and electricity prices used by the ESCO and more importantly, estimate shares of savings for electricity and fuel.
} 


\subsubsection{Baseline Metric}

ESCOs have developed normalization procedures to report actual energy savings and account for significant changes in weather and equipment or building operation, schedule and occupancy levels. We did not alter or revise the normalization techniques used by ESCOs to estimate actual energy savings for individual projects. However, we found that ESCOs reported baseline energy consumption in several different ways, depending on the measures or end uses targeted and their approach to measurement and verification of savings. For example, for lighting projects, many ESCOs reported baseline consumption only for the lighting equipment to be replaced. In contrast, for projects that installed measures across all major end uses, ESCOs tended to report baseline consumption based on total facility energy consumption for all end uses based on analysis of utility bills. This makes it very difficult and not particularly meaningful to compare percentage reductions in energy consumption across projects if total energy consumption at individual facilities is not reported consistently. To address this issue we developed three metrics to categorize baseline consumption reporting methods in order to understand what portion of facility consumption is included in the ESCO's baseline estimate. Projects were coded into one of these metrics:

- Equipment targeted: baseline measurement includes ONLY consumption of equipment to be retrofitted.

- End use targeted: baseline measurement of targeted end use (e.g., lighting) consumption; can include both retrofitted and non-retrofitted equipment.

- Total (utility bill): baseline metric uses utility bill for entire facility being retrofitted.

When possible, ESCOs were asked to classify how they measured baseline energy consumption. In cases where the ESCO could not be reached, we used information from SPC and DSM bidding program protocols, for projects that participated in these programs. In addition, we classified LO projects with high savings $(>80 \%)$ as equipment targeted. We also reviewed each ESCOs discussion of their approach to M\&V and use of specific protocols, which was submitted as part of their NAESCO accreditation application in order to categorize baseline metric for remaining projects. The majority of projects were reported as either total (utility bill) or equipment targeted baseline metric.

\subsubsection{Fuel Conversion}

About 125 projects included measures that involved fuel conversion (e.g., replacement of electric equipment with gas equipment or vice versa). Projects with fuel conversion strategies or measures typically report increases in one energy source (e.g., electricity or fuel) and decreases in another energy source, depending on the type of fuel conversion. Because negative savings are typically reported for fuel conversion projects for one of the energy sources, we excluded fuel conversion projects in reporting aggregate results for electricity or fuel savings. These projects will be treated separately in future analyses. 


\subsection{Average Annual Energy Savings}

In this section, we summarize the results of our analysis of annual energy savings for the 759 projects that reported savings in energy units, focusing on trends in different market segments and by retrofit strategy. One key finding is that reductions in electricity consumption are critically important to project success, accounting on average for over $80 \%$ of total energy savings (on a site energy basis) in this sample of projects. This result for projects in our database is somewhat counter to Cudahy and Dreessen (1996) who estimated that about $55-75 \%$ of the capital invested by ESCOs was for measures that reduced electricity consumption, with the remaining capital $(25-45 \%)$ invested in thermal measures. ${ }^{18}$

Table 4-1 shows the median values and range in electricity savings among different market sectors and segments. Median values for annual electricity savings are 8\% higher for the 222 private sector projects than for the 523 institutional sector projects (1.16 vs. $1.07 \mathrm{M} \mathrm{kWh})$. Among those market segments where our sample includes at least 20 projects, university/colleges $(2.32 \mathrm{M} \mathrm{kWh})$, federal government projects $(2.17 \mathrm{M} \mathrm{kWh})$ and commercialleased offices $(1.62 \mathrm{M} \mathrm{kWh})$ report highest median values for electricity savings. Table $4-1$ also shows the huge range in electricity savings among individual projects (refer to inter-quartile range values in various market segments).

Table 4-1. Average Annual Electricity Savings by Market Segment

\begin{tabular}{|l|c|c|ccc|}
\hline \multicolumn{1}{|c|}{ Market Segment } & \multirow{2}{*}{ N } & \multicolumn{4}{c|}{ Electricity Savings (million kWh) } \\
& & average & 25 val & median & 75 val \\
\hline K-12 Schools & 165 & 1.56 & 0.34 & 0.82 & 1.84 \\
State/local government & 130 & 2.11 & 0.28 & 0.81 & 2.19 \\
University/college & 71 & 4.92 & 0.86 & 2.32 & 5.38 \\
Federal government & 42 & 4.43 & 0.70 & 2.17 & 3.91 \\
Health/hospital & 108 & 1.66 & 0.45 & 0.88 & 1.87 \\
Public Housing & 7 & 3.88 & 2.25 & 3.87 & 4.87 \\
\hline Hotel/hospitality & 9 & 1.53 & 0.63 & 1.22 & 1.86 \\
Office, commercial - leased & 50 & 1.97 & 0.71 & 1.62 & 2.69 \\
Office, commercial - owner-occupied & 51 & 2.80 & 0.44 & 1.43 & 3.32 \\
Retail - single site & 33 & 0.95 & 0.29 & 0.47 & 0.82 \\
Retail - multi-site & 8 & 3.87 & 1.96 & 3.59 & 4.98 \\
Industrial & 49 & 3.69 & 0.42 & 1.09 & 2.44 \\
Residential & 7 & 0.94 & 0.21 & 0.98 & 1.35 \\
Other & 15 & 1.26 & 0.18 & 0.44 & 1.37 \\
\hline Institutional Sector & 523 & 2.43 & 0.40 & 1.07 & 2.46 \\
Private Sector & 222 & 2.36 & 0.42 & 1.16 & 2.51 \\
\hline All Projects* & 754 & 2.40 & 0.40 & 1.08 & 2.46 \\
\hline
\end{tabular}

* includes projects with no market segment

\footnotetext{
${ }^{18}$ Cudahy and Dreessen developed estimates for ESCO investment activity from 1980-1994; investment activity is not the same as share of savings but we might expect a closer correlation.
} 
In order to make more meaningful comparisons of energy savings across market segment, we normalized project savings estimates by floor area: $29 \%$ of the projects in the database had complete data for energy savings, floor area, and market segment (see Figure 4-2). Electricity and fuel savings are included in this analysis. With this adjustment, median energy savings are highest for state/local government and health/hospital projects $\left(18-19 \mathrm{kBtu} / \mathrm{ft}^{2}\right)$ and $13-15$ $\mathrm{kBtu} / \mathrm{ft}^{2}$ for K-12 schools, university/college, federal government and private sector projects. The median savings for all projects is $15 \mathrm{kBtu} / \mathrm{ft}^{2}$. Even after normalizing for floor area, energy savings typically vary by a factor of $3-5$ for the middle $50 \%$ of projects within each market segment (inter-quartile range from $25^{\text {th }}$ to $75^{\text {th }}$ percentile).

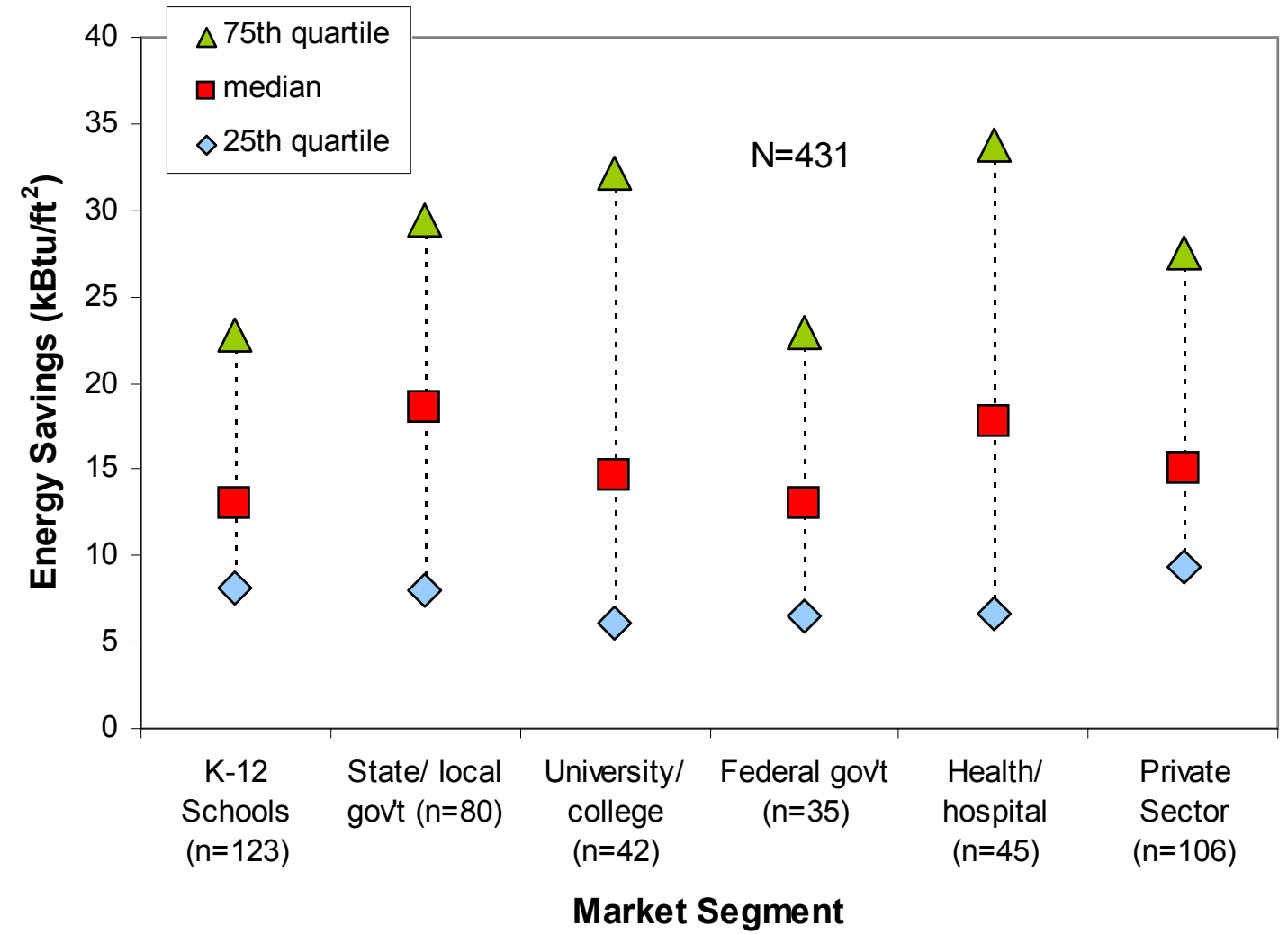

Figure 4-2. Average Annual Energy Savings Normalized by Floor Area (kBtu/ft $\left.{ }^{2}\right)$

\subsection{Percentage Savings Relative to Baseline Energy Consumption}

We also calculated project savings relative to baseline consumption (\% savings), accounting for differences in baseline reporting methods. We divided the projects into two separate baseline categories: total (utility bill) and targeted equipment. Our primary objectives were (1) to assess the extent to which ESCOs reduce consumption in particular end uses through various retrofit strategies and implement projects that would be viewed as "comprehensive" in the sense of producing significant reductions in overall energy consumption at a facility; and (2) to assess the magnitude of lighting energy savings. 
Figure 4-3 shows the range in percent electricity savings for projects using various retrofit strategies. For the 94 LNL projects, median savings are $23 \%$ of the total electric bill baseline. About $70 \%$ of these projects save between $16 \%$ and $45 \%$ on their electric bills. These empirical results give a sense of the extent to which ESCO projects are impacting total facility electricity usage. For the $63 \mathrm{LO}$ projects, median savings are $47 \%$ of the baseline equipment consumption and about half of these projects save between $46 \%$ and $75 \%$. On a one-for-one replacement basis, these results suggest that ESCOs are achieving significant reductions in lighting energy consumption.

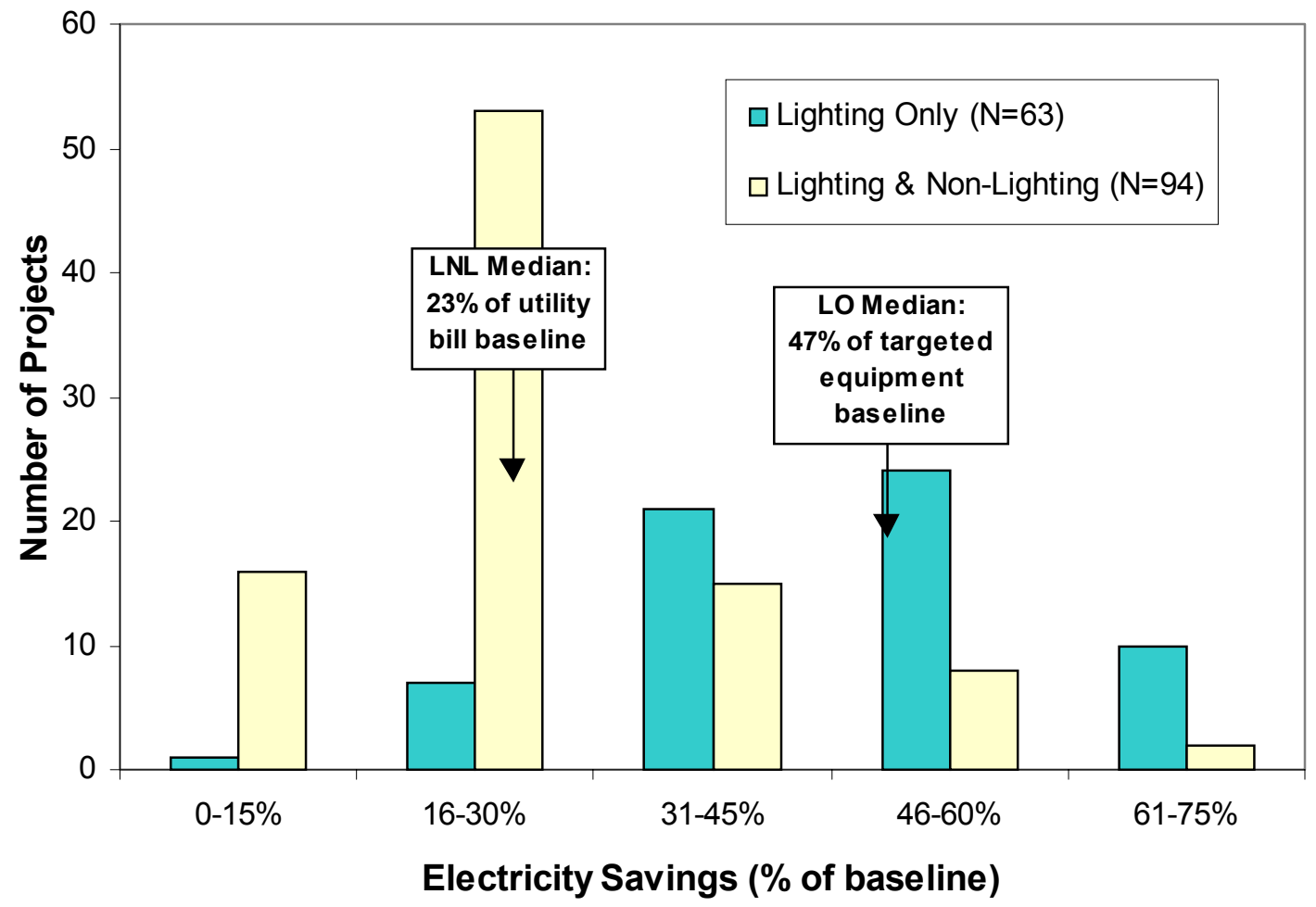

NOTE: All projects in LO sample employ Equipment Targeted baseline metric;

LNL sample includes only Utility Bill baseline

Figure 4-3. Electricity Savings by Retrofit Strategy

We also explored whether the target market segment influenced percent savings for various types of retrofit strategies. Table 4-2 shows median values and range in electricity and gas savings (\%) for institutional and private sector projects, segmented by approach used to estimate baseline consumption. Median values for percent electricity savings are somewhat higher for the 28 private sector than the 62 institutional sector projects (47\% vs. $41 \%)$. $74 \%$ of these projects were LO retrofits. Similarly, for projects that use utility bills to estimate baseline consumption, median values for electricity savings are higher for the 11 private sector than the 96 institutional sector projects (31\% vs. 22\%). Median values for gas savings are 39\% for private sector projects and $20 \%$ for institutional sector projects. Note, however, that there are few private sector projects in this analysis (6-11 projects). 
Table 4-2. Annual Electricity and Gas Savings (\%) in Institutional and Private Sectors

\begin{tabular}{|c|c|c|c|c|c|c|c|c|c|}
\hline \multirow{2}{*}{ Baseline Metric } & \multirow{2}{*}{ Market Segment } & \multicolumn{4}{|c|}{ \% Electricity Savings } & \multicolumn{4}{|c|}{$\%$ Gas Savings } \\
\hline & & $\mathrm{N}$ & 25 val & median & 75 val\% & $\mathrm{N}$ & 25 val & median & $75 \mathrm{val}$ \\
\hline \multirow{3}{*}{ Equipment Targeted } & Institutional Sector & 62 & $33 \%$ & $41 \%$ & $51 \%$ & & & & \\
\hline & Private Sector & 28 & $35 \%$ & $47 \%$ & $57 \%$ & & & & \\
\hline & All projects & 90 & $33 \%$ & $43 \%$ & $53 \%$ & & & & \\
\hline \multirow{3}{*}{ Total (Utility Bill) } & Institutional Sector & 96 & $17 \%$ & $22 \%$ & $28 \%$ & 65 & $9 \%$ & $20 \%$ & $34 \%$ \\
\hline & Private Sector & 11 & $16 \%$ & $31 \%$ & $43 \%$ & 6 & $18 \%$ & $39 \%$ & $53 \%$ \\
\hline & All projects & 107 & $17 \%$ & $22 \%$ & $29 \%$ & 71 & $9 \%$ & $21 \%$ & $34 \%$ \\
\hline
\end{tabular}

\subsection{Demand Savings}

Many projects also reported non-coincident peak demand $(\mathrm{kW})$ savings. We grouped these projects by retrofit strategy for analysis purposes. Table 4-3 shows the range in peak demand savings for projects that employed various retrofit strategies. Median values for peak demand savings are three to four times higher for LNL projects $(933 \mathrm{~kW})$ compared to LO and NLO projects (183 and $279 \mathrm{~kW}$ ). This relationship between retrofit strategies remains even when peak savings are normalized for floor area, which suggests that comprehensive projects produce greater peak demand savings than projects that retrofit a single measure category.

Table 4-3. Demand Savings by Retrofit Strategy

\begin{tabular}{|l|c|c|ccc|}
\hline \multirow{2}{*}{ Retrofit Strategy } & \multirow{2}{*}{$\mathbf{N}$} & \multicolumn{4}{|c|}{ Savings (kW) } \\
& & average & 25 val & median & 75 val \\
\hline Lighting Only & 236 & 554 & 83 & 183 & 484 \\
Lighting \& Non-Lighting & 210 & 2,745 & 294 & 933 & 3,149 \\
Non-Lighting Only & 52 & 2,604 & 157 & 279 & 976 \\
\hline
\end{tabular}

However, in percentage terms, the ability to reduce peak demand using various retrofit strategies looks very different, mainly because of the different approaches used to estimate baseline consumption. Median peak demand savings for LO projects is $47 \%$ of the targeted equipment, similar to reported electricity savings (see Figure 4-4). For LNL and NLO projects, the reductions are $21 \%$ and $13 \%$, respectively. We compared these values between institutional and private sectors, and found little difference.

We also estimated the implied conservation load factor (CLF) for LO projects based on measured $\mathrm{kW}$ and $\mathrm{kWh}$ consumption and savings. CLF, which is analogous to the capacity factor, is a way to measure the peak demand avoided from a given level of energy savings, as well as the value of conserved energy (Koomey et al 1989). It is a ratio of the annual average load savings (the ECMs expected kWh savings divided by 8760 hours) to the peak load savings (the $\mathrm{kW}$ savings at the time of peak demand). A conservation technology that saves a constant amount of power on a continuous basis (e.g., all hours of the year) has a CLF of 1.0. For lighting projects, the median value for CLF was 0.44 . A CLF of 0.44 suggests that typical operating time for this lighting equipment was 3854 hours/year. 


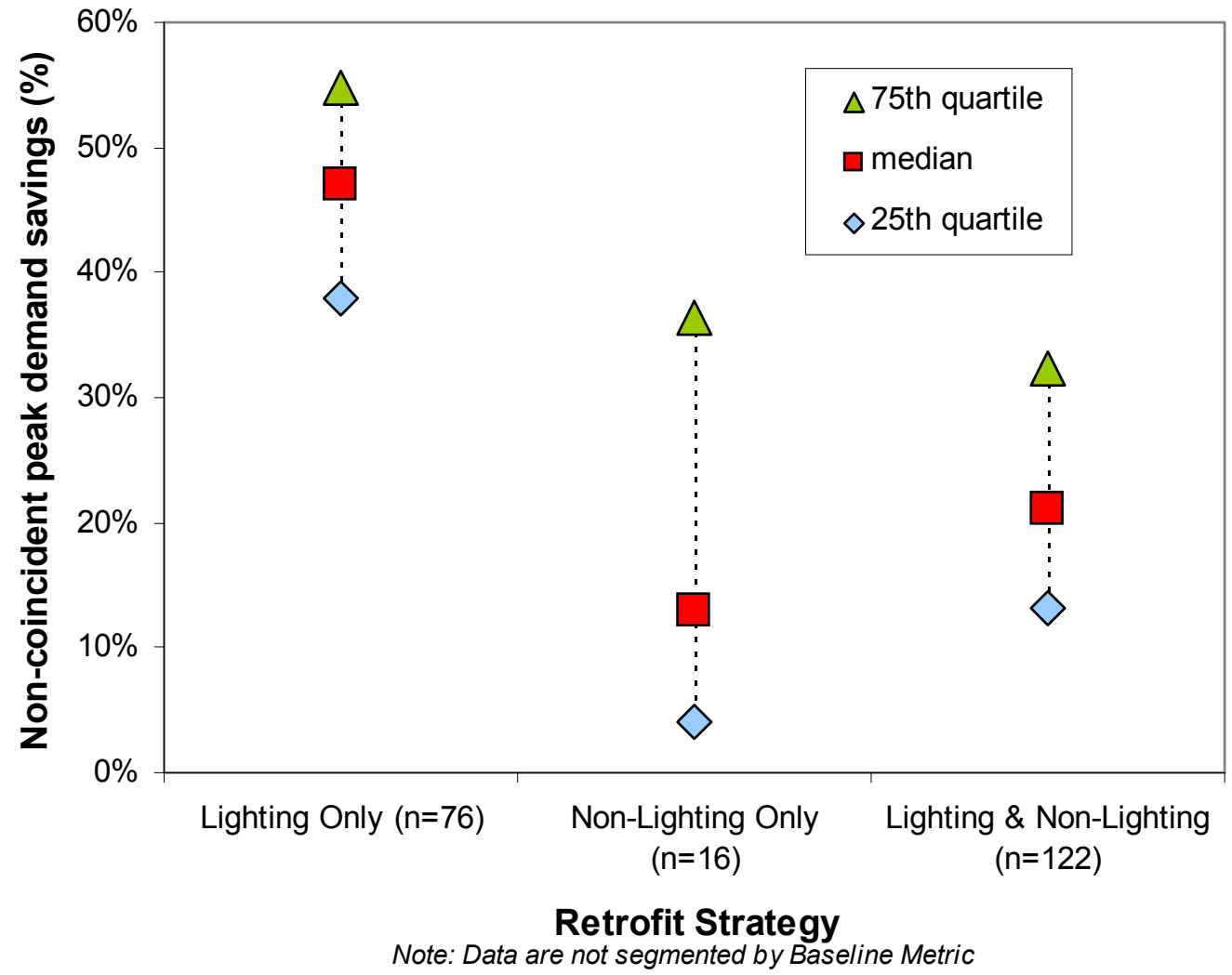

Figure 4-4. Non-Coincident Peak Demand Savings (\%)

\subsection{Predicted vs. Actual Savings}

The relative accuracy of ESCO savings estimates (the relationship between predicted and actual savings) is of direct importance for customers, ESCOs, policymakers, and financial institutions. Accurate savings estimates are critical for customers and financial institutions to judge the technical merit and economic attractiveness of proposed projects. Analysis of the actual track record of ESCOs in delivering energy and peak demand savings helps policymakers evaluate claims of energy-efficiency advocates about the role of ESCOs and energy efficiency in addressing broader energy or environmental policy issues.

About $28 \%$ of projects in the database reported both actual and predicted energy savings (see Figure 4-5). Thirteen percent of these projects stipulated savings for all installed measures (100\% stipulated savings). This means that ESCOs were just imputing and setting actual savings equal to their pre-retrofit engineering estimate (actual = predicted savings). For the remaining 314 projects, actual savings exceeded predicted savings in $63 \%$ of the cases. ${ }^{19} \mathrm{We}$ also examined the relative accuracy of savings and found that $59 \%$ of projects realized savings within $15 \%$ of ESCO predictions.

\footnotetext{
${ }^{19}$ In these projects, we do not know the extent to which ESCOs stipulate savings for some of the measures.
} 


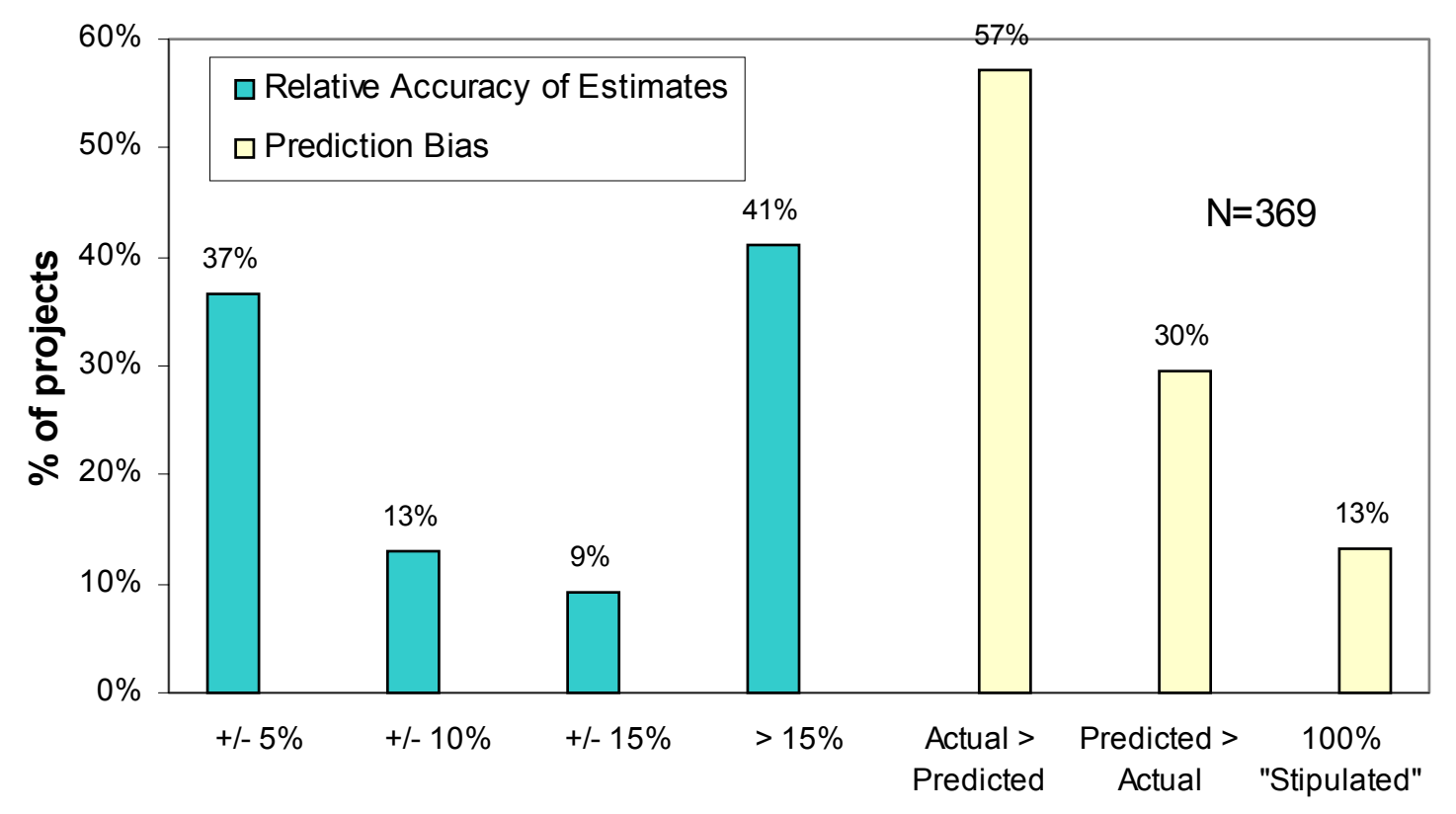

Figure 4-5. Relative Accuracy of ESCO Savings Predictions

We segmented projects by type of retrofit strategy to examine these results more closely. We found that ESCOs tend to stipulate savings more frequently for LO (22\%) and NLO projects $(30 \%)$ than LNL projects $(<10 \%)$ (see Figure 4-6). Of the projects where actual savings were not $100 \%$ stipulated, ESCOs overestimate savings for LO projects more often than for either LNL or NLO projects. Just over half of LO projects that were not stipulated reported actual energy savings that exceeded predicted savings. Actual energy savings of more comprehensive projects exceeded savings predictions more consistently, in $69 \%$ and $79 \%$ of cases for LNL and NLO, respectively.

The extent to which actual savings diverge from predicted savings is as important as the likelihood that predicted savings may exceed actual savings. Figure 4-7 shows how closely predicted savings match actual savings for different retrofit strategies. The majority of LO projects report actual project energy savings within 5\% of predicted savings and less than $20 \%$ of these projects were off by more than $15 \%{ }^{20}$ This tends to confirm anecdotal evidence that the ESCO industry has a good handle on predicting the performance of high-efficiency lighting equipment. In contrast, the majority of LNL projects and 33\% of NLO projects deviate by more than $15 \%$ of projected savings.

\footnotetext{
${ }^{20}$ Note that about $23 \%$ of these projects are "stipulating" savings, which means $100 \%$ agreement de facto.
} 


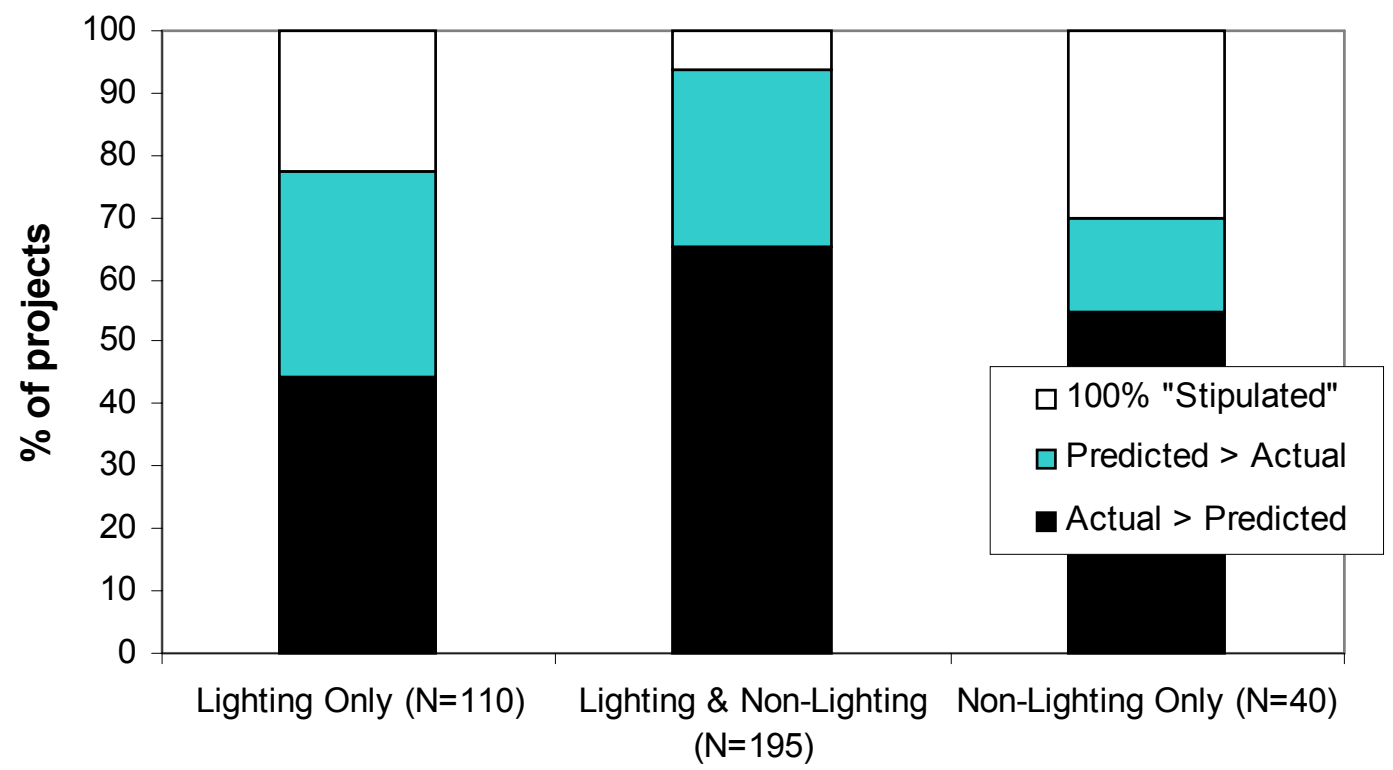

Retrofit Strategy

Figure 4-6. Actual vs. Predicted Savings by Retrofit Strategy

However, upon closer examination of the LNL and NLO projects where actual and predicted savings vary by $15 \%$ or more, we find that, in most cases, ESCOs are being conservative in their forecasts of energy savings for these types of retrofit projects. Actual energy savings are more likely to exceed predictions in these projects; and the customer will typically enjoy savings beyond the ESCO's projections.

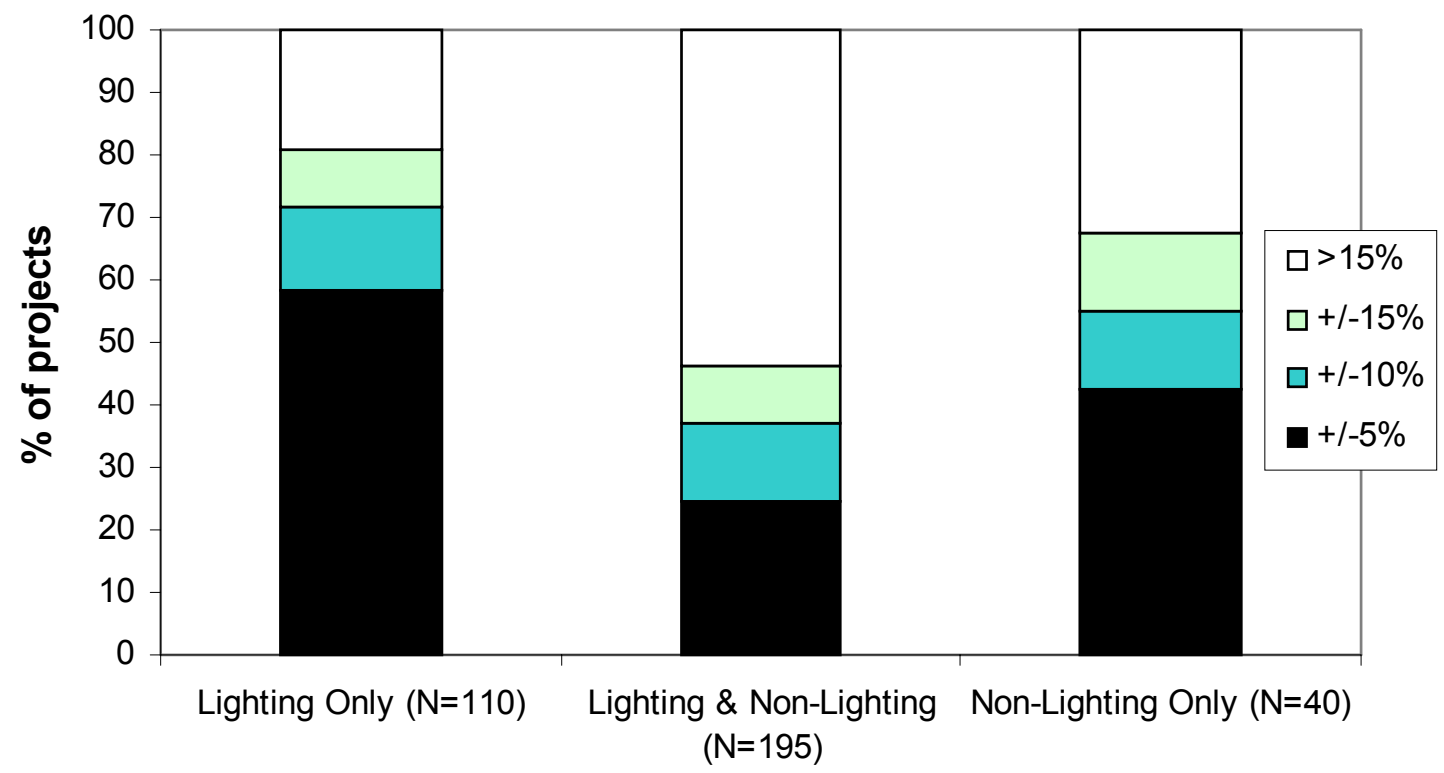

\section{Retrofit Strategy}

Figure 4-7. Difference Between Predicted and Actual Savings by Retrofit Strategy 


\subsection{Guaranteed vs. Predicted Savings}

Guaranteed savings is the most popular type of performance-contracting arrangement used by ESCOs. We are interested in the relationship between savings that were guaranteed to the customer by the ESCO and the ESCO's predicted savings estimates. The guaranteed savings level establishes a "floor" on project benefits, while the ratio of guaranteed to predicted savings provides an indicator of how much performance risk the ESCO is willing to assume.

We compared the predicted and guaranteed savings for projects with available data $(\mathrm{N}=162)$; projects were segmented by company to determine strategies used by individual ESCOs. Of the 15 different ESCOs that had projects with projected and guaranteed electricity and/or fuel savings, we found that seven companies consistently guaranteed $100 \%$ of predicted savings. Six companies guaranteed between $50-100 \%$ of predicted savings, and two companies actually guaranteed less than $50 \%$ of predicted savings. Among the eight ESCOs where guaranteed savings were less than predicted savings, we could find no discernible pattern or formula (e.g., guaranteed savings are set at $80 \%$ of predicted savings), but rather the ratio of guaranteed to predicted savings tended to be project-specific. Overall, we found that the relationship between guaranteed and predicted savings is driven mainly by individual ESCO business practices rather than by retrofit strategy.

\subsection{Persistence of Savings}

One of the claimed benefits of performance contracting is that because ESCOs establish longterm business relationships with customers through ongoing contractual arrangements, savings from retrofits are more likely to persist over time. To explore this issue, ESCOs were requested to provide annual energy savings data for their projects (if applicable). Thus far, in reporting verified energy savings, most ESCOs have typically averaged annual energy savings over the contract term, rather than reporting yearly values. Moreover, in many projects, ESCOs report that additional measures/retrofits have been implemented at the facility over time as customers approve additional energy-efficiency investments. ESCOs tend to combine the results of multiple phases in their reporting of project savings.

Given these limitations, we were able to analyze multi-year savings data for only 29 projects (after excluding projects with 100\% stipulated savings data). Among this small sample, 20 projects reported savings for more than two years. We found that the majority of projects $(72 \%)$ actually reported increased electricity savings over time (up to four years). ${ }^{21}$ To adequately evaluate the persistence of savings, yearly data for more projects are needed.

\footnotetext{
${ }^{21}$ Many of the projects with more than two years of savings data reported fluctuating savings (decreasing one year, increasing the next).
} 


\section{Project Economics - What are the Direct Economic Benefits of ESCO Projects from a Customer Perspective?}

\subsection{Summary}

- The direct economic benefits of each project from the customer's perspective were estimated based on the value of energy and non-energy savings (e.g., O\&M savings, water savings) over the project's expected economic lifetime. Our analysis focused on three economic indicators: project net benefits, benefit/cost (B/C) ratio, and simple payback time (SPT).

- For the 1082 projects with both cost and savings data (73\% of the database projects), net benefits (benefits minus costs) are $\sim \$ 1.62 \mathrm{~B}$ using nominal discount rates of $7 \%$ and $10 \%$ respectively for institutional sector and private sector projects. ${ }^{22}$ Net benefits for our sample of projects decrease to $\$ 874 \mathrm{M}$ at higher discount rates. About $90 \%$ of the direct economic benefits derive from the value of the saved energy, while about $10 \%$ result from non-energy savings.

- The vast majority of the projects in our database appear to be cost-effective based solely on their direct economic benefits to customers. We estimate that about $87 \%$ of the 309 private sector projects and $70 \%$ of the 771 institutional sector projects have $\mathrm{B} / \mathrm{C}$ ratios greater than one.

- The median $\mathrm{B} / \mathrm{C}$ ratio is 1.6 for institutional sector projects using a $7 \%$ nominal discount rate and 1.3 using a $10 \%$ discount rate. The median $\mathrm{B} / \mathrm{C}$ ratio ranges between 2.1 and 1.6 for private sector projects, depending on choice of discount rates.

- The median SPT is about seven years for the 788 projects in the institutional sector. About $44 \%$ of institutional sector projects have a SPT of six years or less. The median SPT is about three years for the 319 private sector projects. About $83 \%$ of private sector projects have a SPT of six years or less.

- Several other factors influence project economics, including state or federal legislation that specifies maximum contract term for performance contracts, choice of retrofit strategy, and financial incentives obtained from utility or public purpose energy-efficiency programs.

\subsection{Approach}

\subsubsection{Direct Economic Benefits}

The economic value of an ESCO project is difficult to quantify because it typically involves estimating both direct (e.g., value of saved energy, O\&M savings) and indirect benefits. Moreover, in estimating benefits, choices regarding several key assumptions (e.g., economic

\footnotetext{
${ }^{22} \mathrm{We}$ used high and low nominal discount rates for the economic analysis. Lower discount rates were $7 \%$ and $10 \%$ respectively for institutional and private sector projects, while higher rates were $10 \%$ and $15 \%$ respectively for institutional and private sector projects.
} 
lifetime of ECMs, future energy escalation rates, appropriate discount rate) can significantly impact project economics. The most tangible, direct economic benefits are avoided utility, energy, and operations and maintenance (O\&M) expenditures that occur as a result of the installed measures or strategies.

\subsubsection{Other Benefits}

ESCO projects may also yield a number of indirect benefits such as increased productivity, improved amenity and comfort levels, and environmental improvements (e.g., reduced air pollution and carbon emissions). Recent market surveys have found that customers value the increased amenity and reduced O\&M burden that result from upgrading outdated equipment through efficiency retrofits (Donahue 1998; Birr 2001). Decreasing energy consumption and the resulting cost savings may help fund the replacement of equipment that otherwise could not be financed. In addition, energy-efficiency projects that reduce electricity consumption also provide environmental benefits to society in the form of reduced air emissions from generation plants. In some instances, customers may be able to capture these environmental benefits either through financial incentives/credits or emission allowance trading. ESCOs do not report this information; thus environmental benefits are not currently reflected in our economic analysis.

Because it is difficult to assign a dollar value to indirect benefits, our analysis focuses only on quantifying the direct economic benefits of ESCO projects. Thus, our approach is conservative and is likely to underestimate the actual value of these projects to the customer.

\subsection{Economic Indicators}

For each project, we calculated the direct economic benefits, benefit/cost (B/C) ratio, and simple payback time (SPT).

\subsubsection{Direct Economic Benefits (Gross)}

Gross benefits are the discounted monetized value of expected direct economic benefits (i.e., energy and non-energy savings) expected to occur over the economic lifetime of the project's measures. See Appendix $\mathbf{C}$ for details on calculations and embodied assumptions.

\subsubsection{Direct Economic Benefits (Net)}

Project net benefits are calculated by subtracting project costs from gross direct economic benefits. ${ }^{23}$

\subsubsection{Benefit/Cost Ratio}

The $\mathrm{B} / \mathrm{C}$ ratio is calculated by dividing gross project benefits by project costs.

\footnotetext{
${ }^{23}$ Project costs are assumed to be paid up-front in year one at time of customer acceptance; ESCOs did not report on-going project service costs, such as maintenance and measurement/verification costs, so there were no annual recurring project costs to discount.
} 


\subsubsection{Simple Payback Time}

The simple payback time (SPT) is the time (in years) that savings must be realized before savings will offset project costs. The dollar value of energy savings was determined by multiplying the average annual energy savings by the appropriate price for that energy source (e.g., electricity, gas) in the year the project was completed. If actual energy savings were not available, we used the dollar value of savings as reported by the ESCO.

\subsection{Direct Economic Benefits and Benefit/Cost Analysis}

We attempted to account for important differences in motivation, access to capital, and planning time horizon between institutional and private sector markets in our economic analysis. Based on customer market research and discussions with ESCOs, institutional sector customers typically have longer planning horizons, can access third party financing at attractive interest rates, and often issue solicitations for performance contracts that allow for relatively long economic payback times (e.g., 10-25 years). In contrast, in evaluating energy-efficiency project proposals, private sector customers often have high investment hurdle rates (which translate into shorter payback periods), shorter planning horizons (e.g., for leased space), and face higher interest rates for third party financing (e.g., due to risks of plant shutdown, business risks). To reflect these differences, we used lower nominal discount rates in our economic analysis of institutional sector projects ( $7 \%$ and $10 \%)$ than for private sector projects $(10 \%$ and $15 \%)$.

Table 5-1 summarizes results of the economic analysis for various institutional market segments including project costs, net economic benefits and $\mathrm{B} / \mathrm{C}$ ratio using our selected discount rates. We estimate that the 771 institutional sector projects achieved $\sim \$ 1.3 \mathrm{~B}$ in net economic benefits with a median $\mathrm{B} / \mathrm{C}$ ratio of $\sim 1.6$. At the higher discount rate of $10 \%$, net benefits are $\$ 700 \mathrm{M}$ for these projects with a median $\mathrm{B} / \mathrm{C}$ ratio of 1.3 .

Table 5-1. Direct Economic Benefits and B/C Ratio for Institutional Sector Projects

\begin{tabular}{|c|c|c|c|c|c|c|c|c|c|c|c|c|}
\hline \multirow{3}{*}{ Market Segment } & \multirow{3}{*}{$\mathbf{N}$} & \multirow{3}{*}{$\begin{array}{c}\text { Total } \\
\text { Project } \\
\text { Costs } \\
\text { (\$M) }\end{array}$} & \multicolumn{5}{|c|}{ 7\% Discount Rate } & \multicolumn{5}{|c|}{$10 \%$ Discount Rate } \\
\hline & & & \multicolumn{2}{|c|}{$\begin{array}{c}\text { Direct Economic } \\
\text { Benefits }(\$ M)\end{array}$} & \multicolumn{3}{|c|}{ Benefit/Cost Ratio } & \multicolumn{2}{|c|}{$\begin{array}{c}\text { Direct Economic } \\
\text { Benefits }(\$ M)\end{array}$} & \multicolumn{3}{|c|}{ Benefit/Cost Ratio } \\
\hline & & & Gross & Net & 25 val & median & $75 \mathrm{val}$ & Gross & Net & 25 val & median & $75 \mathrm{val}$ \\
\hline K-12 schools & 289 & 714 & 803 & 88 & 0.7 & 1.0 & 1.7 & 633 & -81 & 0.5 & 0.8 & 1.3 \\
\hline State/ local gov't & 159 & 276 & 581 & 305 & 1.0 & 1.7 & 3.0 & 471 & 195 & 0.9 & 1.4 & 2.4 \\
\hline Univ./ colleges & 100 & 301 & 809 & 508 & 1.2 & 1.7 & 3.1 & 637 & 336 & 0.9 & 1.4 & 2.4 \\
\hline Federal gov't & 58 & 153 & 280 & 126 & 0.9 & 1.7 & 3.2 & 225 & 72 & 0.8 & 1.4 & 2.6 \\
\hline Health/ hospital & 134 & 136 & 365 & 229 & 1.6 & 2.3 & 3.8 & 295 & 159 & 1.3 & 1.9 & 3.3 \\
\hline Public Housing & 31 & 96 & 140 & 45 & 0.7 & 1.5 & 1.8 & 114 & 18 & 0.6 & 1.2 & 1.4 \\
\hline Institutional Sector & 771 & 1,677 & 2,978 & 1,301 & 0.9 & 1.6 & 2.5 & 2,375 & 698 & 0.7 & 1.3 & 2.0 \\
\hline
\end{tabular}




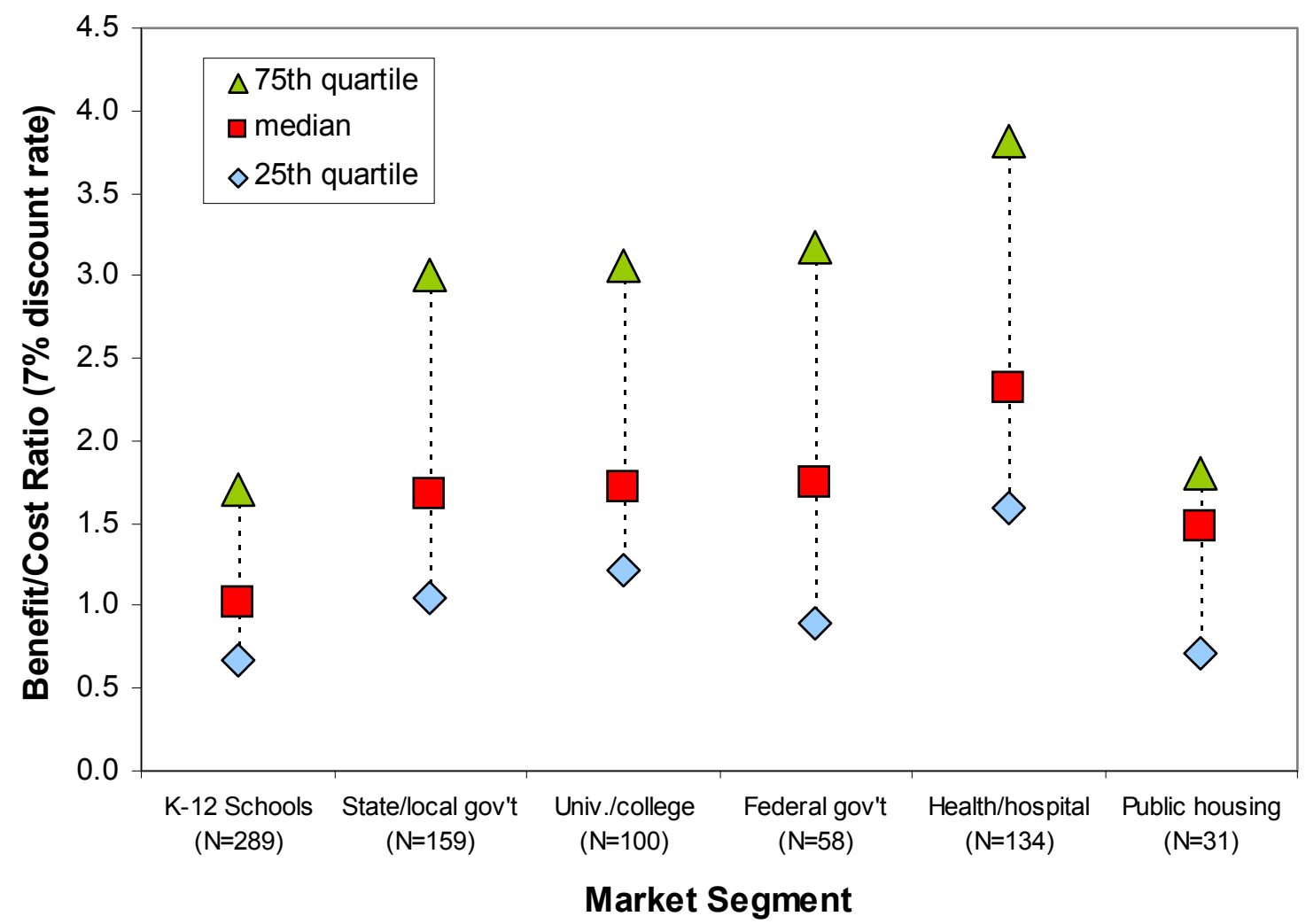

Figure 5-1. Benefit/Cost Ratios for Institutional Sector Projects

Figure 5-1 shows the range in $\mathrm{B} / \mathrm{C}$ ratios between institutional market segments. Median $\mathrm{B} / \mathrm{C}$ values are higher in the 134 health/hospital projects (2.3) compared to other institutional market segments. Given dramatic changes in this industry (e.g., rise of health maintenance organizations, privatization), we suspect that energy-efficiency decision-making criteria for an increasing number of hospitals is evolving towards a private (rather than public) sector perspective. In other sectors, median $\mathrm{B} / \mathrm{C}$ ratios are 1.7 for state/local government, university/colleges and federal government, and 1.0 for K-12 Schools. At the $7 \%$ discount rate, about $70 \%$ of the 771 institutional sector projects have $\mathrm{B} / \mathrm{C}$ ratios greater than 1.0 .

We believe that there are several factors that help explain why some projects have $\mathrm{B} / \mathrm{C}$ ratios less than one: (1) the ESCO may have used different retail energy prices, utility rates, and energy escalation rates than assumptions used in our analysis ${ }^{24}{ }^{24}$ (the project's value to the customer may have been driven by other benefits (e.g., new equipment that increased productivity or amenity) which are not explicitly accounted for in our analysis of direct economic benefits, (3) for the $\sim 300$ projects that participated in a REEP program, the customer may have received some or all of the financial incentives, which we have not accounted for in this analysis, and (4) the project's actual performance may have been significantly less than projected. In the case of

\footnotetext{
${ }^{24}$ Our analysis relies on EIA data statewide average electricity and gas prices expressed in volumetric terms only (e.g., cents $/ \mathrm{kWh}$ or $\$ /$ therm); ESCOs are likely to have used the actual tariff rate of the local utility (which might include both demand and energy charges) in estimating dollar savings. See Appendix C for our data sources.
} 
schools, we might expect that $\mathrm{B} / \mathrm{C}$ ratios would be lower (and payback time longer) because of the lower operating hours of their facilities compared to most other institutional sector projects.

Table 5-2 highlights results for the 309 private sector projects, categorized into three broad market segments (commercial, ${ }^{25}$ industrial, and other ${ }^{26}$ projects). We estimate that the 309 private sector projects achieved $\sim \$ 320 \mathrm{M}$ in net economic benefits with a median $\mathrm{B} / \mathrm{C}$ ratio of 2.1. At the higher discount rate of $15 \%$, net benefits are $\$ 180 \mathrm{M}$ for these projects with a median $\mathrm{B} / \mathrm{C}$ ratio of 1.6 .

Table 5-2. Direct Economic Benefits and Benefit/Cost Ratio for Private Sector Projects

\begin{tabular}{|c|c|c|c|c|c|c|c|c|c|c|c|c|}
\hline \multirow{3}{*}{ Market Segment } & \multirow{3}{*}{$\mathbf{N}$} & \multirow{3}{*}{$\begin{array}{c}\text { Total } \\
\text { Project } \\
\text { Costs } \\
(\$ M) \\
\end{array}$} & \multicolumn{5}{|c|}{$10 \%$ Discount Rate } & \multicolumn{5}{|c|}{$15 \%$ Discount Rate } \\
\hline & & & \multicolumn{2}{|c|}{$\begin{array}{c}\text { Direct Economic } \\
\text { Benefits }(\$ M)\end{array}$} & \multicolumn{3}{|c|}{ Benefit/Cost Ratio } & \multicolumn{2}{|c|}{$\begin{array}{c}\text { Direct Economic } \\
\text { Benefits }(\$ M)\end{array}$} & \multicolumn{3}{|c|}{ Benefit/Cost Ratio } \\
\hline & & & Gross & Net & 25 val & median & 75 val & Gross & Net & $25 \mathrm{val}$ & median & 75 val \\
\hline Commercial* $^{*}$ & 192 & 137 & 349 & 212 & 1.7 & 2.2 & 3.7 & 265 & 128 & 1.3 & 1.7 & 2.8 \\
\hline Industrial & 76 & 95 & 181 & 86 & 1.3 & 1.8 & 2.7 & 136 & 41 & 1.0 & 1.4 & 2.2 \\
\hline Other & 41 & 28 & 47 & 18 & 0.8 & 1.8 & 2.7 & 34 & 6 & 0.7 & 1.3 & 2.0 \\
\hline Private sector & 309 & 260 & 576 & 317 & 1.4 & 2.1 & 3.2 & 435 & 176 & 1.1 & 1.6 & 2.6 \\
\hline
\end{tabular}

${ }^{*}$ Commercial includes hotels/hospitality, retail space, and commercial offices.

${ }^{* *}$ Other includes residential and projects that were classified as "other" by the ESCO.

Figure 5-2 shows the range in $\mathrm{B} / \mathrm{C}$ ratios for private sector market segments. At a $10 \%$ discount rate, the median $\mathrm{B} / \mathrm{C}$ ratio is highest for the commercial market segment. About $87 \%$ of the private sector projects have $\mathrm{B} / \mathrm{C}$ ratios greater than 1.0 .

To summarize, we combine the economic analysis results for institutional and private sector projects. For the 1080 projects with both cost and savings data (73\% of the database), net economic benefits are $\sim \$ 1.62 \mathrm{~B}$, using the lower discount rates for institutional and private sector projects. About $90 \%$ of the direct economic benefits derive from the value of the saved energy, while about $10 \%$ result from non-energy savings. At the higher discount rates, net benefits for the project sample decrease by almost half to $\$ 880 \mathrm{M}$. These results illustrate the importance of choice of discount rate in estimating net benefits.

\footnotetext{
${ }^{25}$ Because of small sample sizes, we aggregated results for hotels/hospitality, retail space, and commercial offices into a commercial sector market segment.

${ }^{26}$ Other includes residential and projects that were classified as "other."
} 


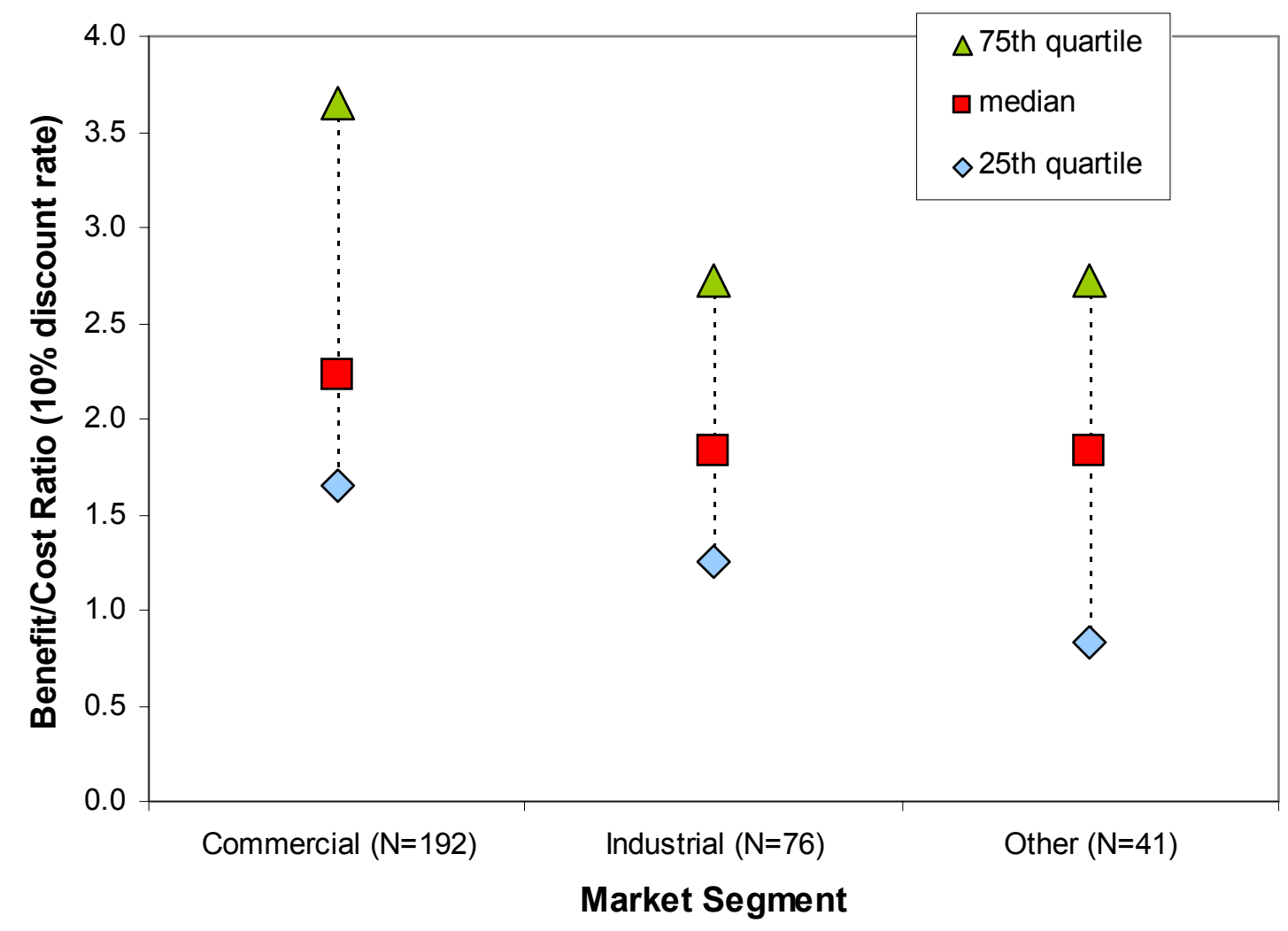

Figure 5-2. Benefit/Cost Ratio of Private Sector Projects

\subsection{Simple Payback Time of Institutional and Private Sector Projects}

Figure 5-3 displays the range in SPT for 788 institutional sector projects grouped by market segment. ${ }^{27}$ Approximately $44 \%$ of institutional sector projects have a SPT of six years or less; the median SPT for all institutional projects is seven years. Within the institutional market, median payback times are shorter (4 years) among our sample of 139 health/hospital and 159 state/local government projects compared to the 296 K-12 schools projects with a median payback time of around 10 years.

\footnotetext{
${ }^{27}$ For those projects that received a rebate, we subtracted $100 \%$ of the reported rebate from project costs. For projects that participated in other REEP programs, $50 \%$ of the reported incentives were subtracted from project costs. If the project did not report incentives or participation in a REEP, total project costs were not altered.
} 


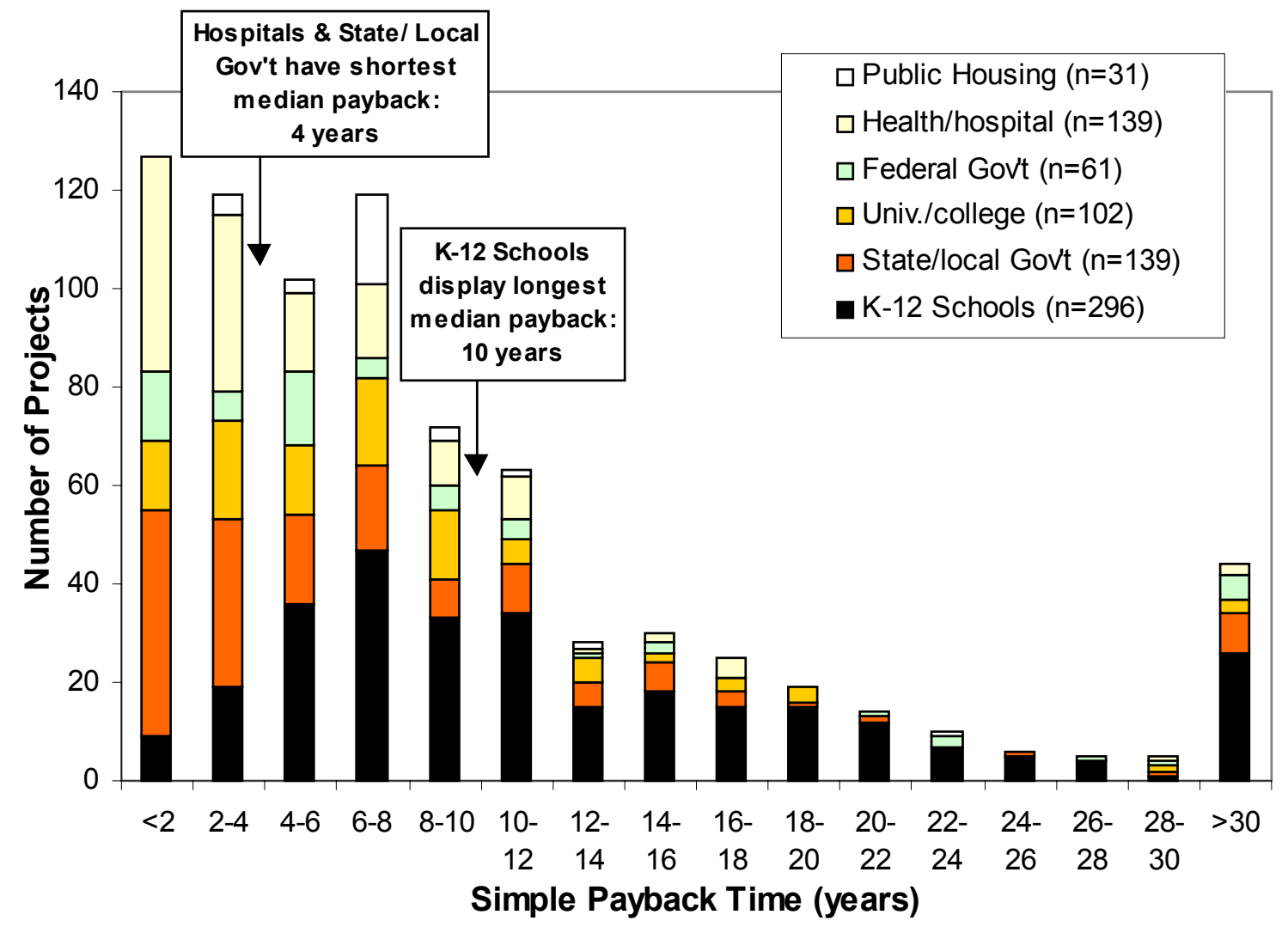

Figure 5-3. Simple Payback Time of Institutional Sector Projects

Figure 5-4 shows a similar breakdown of SPT for 319 private sector projects grouped into three broad market segments (commercial, industrial, and other/residential projects). Approximately $83 \%$ of private sector projects had a SPT of six years or less. The median SPT for private sector projects is three years. 


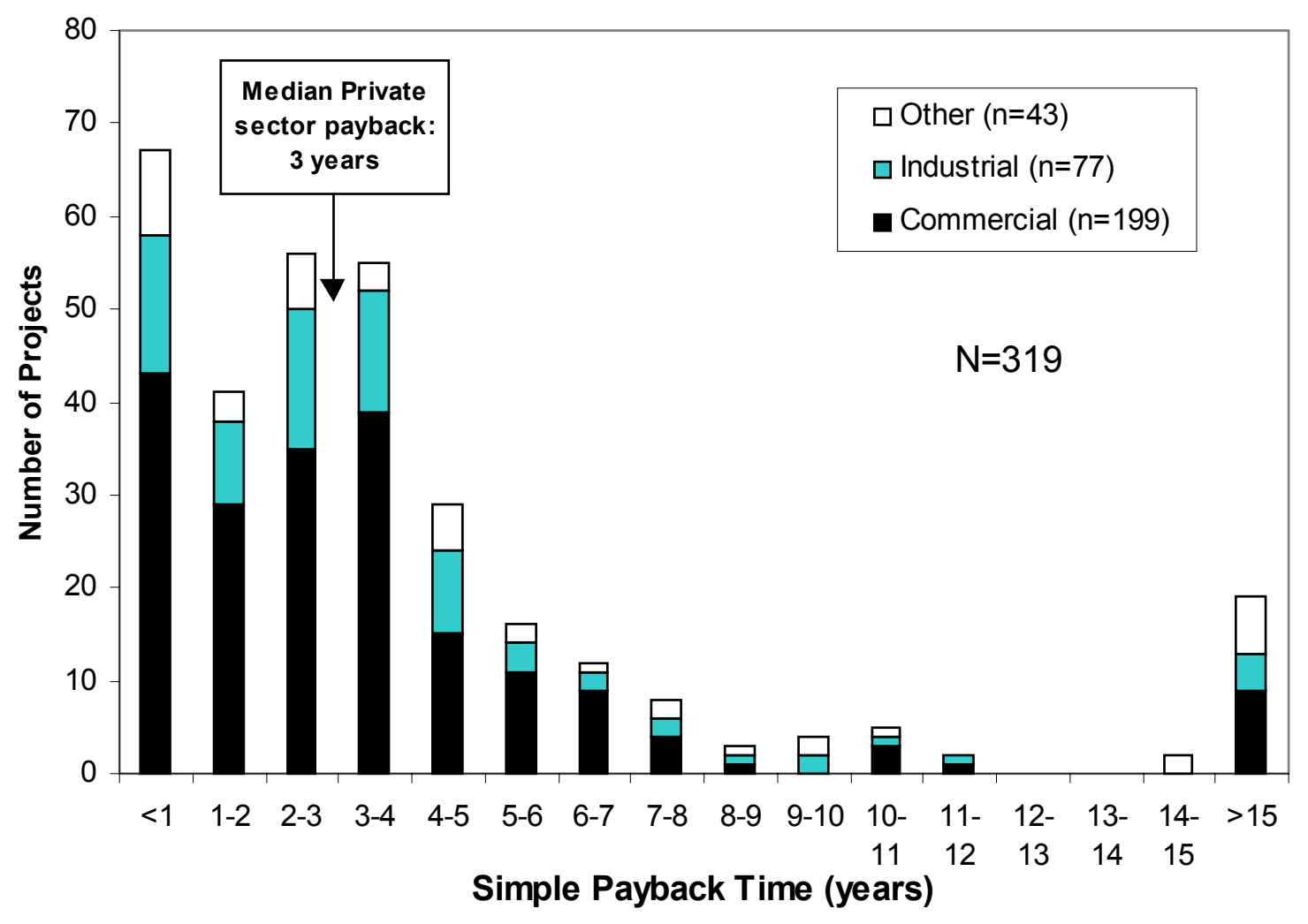

Figure 5-4. Simple Payback Time of Private Sector Projects

\subsection{Other Factors that Influence Project Economics}

Several other factors could potentially influence project economics, including state or federal performance-contracting guidelines, retrofit strategy, facility size (floor area), REEP participation, and differences between our assumed retail rates and those actually paid by the customer. Here we discuss our exploratory analysis of these factors.

\subsubsection{State Performance-Contracting Guidelines}

Many states specify the maximum contract term for a performance contract in their enabling legislation. The underlying intent of these provisions is to articulate the state's willingness to undertake comprehensive projects that install and finance high-efficiency equipment and other measures up to a cost-effectiveness threshold. Based on research conducted by NAESCO, the maximum contract term allowed by states can be summarized as follows: 2 states allow 5-6 year contract terms, 13 states allow 10-year contracts, 2 states allow 12-year contracts, 9 states allow 15-year contracts, 5 states allow 18-20 year contracts and five states allow 25-year or longer contracts. Eight states do not specify a maximum contract term (Donahue 2001). Given the fact that 34 states allow maximum contract terms of 10 or more years, it should not be surprising that energy-efficiency equipment and measures that are installed in institutional sector projects have long expected economic lifetimes and SPT. 


\subsubsection{Retrofit Strategy}

We grouped projects by retrofit strategy and compared their net benefits normalized for floor area. Table 5-3 shows net benefits for each of our three defined retrofit strategies, normalized by floor area. LO projects have the highest net benefits at $\$ 0.80 / \mathrm{ft}^{2}$.

Table 5-3. Impact of Retrofit Strategy on Direct Economic Benefits

\begin{tabular}{|c|c|c|c|c|}
\hline \multirow[t]{2}{*}{ Retrofit Strategy } & \multirow[t]{2}{*}{$\mathbf{N}$} & \multicolumn{3}{|c|}{$\begin{array}{l}\text { Net Benefits }\left(\$ / \mathrm{ft}^{2}\right) \\
10 \% \text { Discount Rate }\end{array}$} \\
\hline & & $25 \mathrm{val}$ & median & $75 \mathrm{val}$ \\
\hline Lighting Only & 118 & 0.1 & 0.8 & 2.5 \\
\hline Lighting \& Non-Lighting & 354 & -1.2 & 0.3 & 2.3 \\
\hline Non-Lighting Only & 60 & -0.8 & 0.4 & 1.5 \\
\hline All projects & 576 & -0.7 & 0.5 & 2.5 \\
\hline
\end{tabular}

We also compared SPT for projects grouped by retrofit strategy and market sector (see Table 5-4). First, note the higher share of LO projects in the private sector compared to the institutional market (43\% vs. 20\%). Second, median payback times for LO projects are relatively short in both institutional and private sector projects ( 2 years). Third, median payback times are significantly longer for institutional than private sector projects for LNL and NLO projects ( 8 vs. 4 and 2 years). As these retrofit categories are quite broad, it appears that private sector projects selectively focus on individual measures with shorter payback times.

Table 5-4. Impact of Retrofit Strategy on Simple Payback Time

\begin{tabular}{|l|c|ccc|c|ccc|}
\hline \multirow{3}{*}{ Retrofit Strategy } & \multicolumn{6}{|c|}{ Simple Payback Time (years) } \\
\cline { 2 - 10 } & \multicolumn{4}{|c|}{ Institutional Sector } & \multicolumn{4}{c|}{ Private Sector } \\
& $\mathrm{N}$ & 25 val & median & 75 val & $\mathrm{N}$ & 25 val & median & 75 val \\
\hline Lighting Only & 146 & 1 & 2 & 4 & 128 & 1 & 2 & 4 \\
Lighting \& Non-Lighting & 498 & 5 & 8 & 13 & 97 & 3 & 4 & 6 \\
Non-Lighting Only & 98 & 2 & 8 & 14 & 73 & 1 & 2 & 5 \\
\hline
\end{tabular}

\subsubsection{Facility Size}

We grouped projects by facility size $\left(<400,000 \mathrm{ft}^{2}\right.$ and $\left.>=400,000 \mathrm{ft}^{2}\right)$ and found little difference in SPT between the two size categories. Specifically, institutional sector projects had median SPT of eight and seven years in facilities that were less than or greater than $400,000 \mathrm{ft}^{2}$, respectively. Median payback times were the same (3 years) in private sector projects segmented into the two facility size groups. Thus, facility size does not appear to be an important factor in explaining differences in SPT within institutional or private sector markets.

\subsubsection{Impact of REEP Incentives on Project Economics}

Financial incentives received by a customer from a ratepayer-funded energy-efficiency program (REEP) can significantly impact project economics. ESCOs often leverage the value of these incentives by passing some or all of the incentive payment directly to the customer, which effectively reduces the cost of the project. ESCOs were requested to report financial incentives 
from a REEP program, but were not asked to specify the contractual terms related to the incentive payment (i.e., received by ESCO, customer, or some sharing arrangement). About $30 \%$ of the projects ( 325 of 1089 projects) included in the economic analysis provided information on REEP financial incentives.

For analysis purposes, projects were segmented into three broad groups: (1) those that did not participate in a REEP, (2) projects that participated in a REEP, and (3) REEP participation unknown. Projects that participated in a REEP were grouped into four categories: rebate programs, DSM bidding programs, SPC programs in California, New York, and Texas, and New Jersey SPC programs ("NJ SPC") ${ }^{28}$. Projects that reported REEP incentives were analyzed in two ways: (1) assume that none of the incentives were received by the customer and (2) assume that $100 \%$ of the reported rebate amount and $50 \%$ of the incentives for all other program types were received by the customer and thus subtracted from project costs. ${ }^{29}$ We believe that the second scenario comes closest to reflecting actual market practices, while the first scenario is quite conservative and provides an upper bound estimate of SPT from the customer's perspective.

Figure 5-5 shows median SPT (bars) and the $25^{\text {th }}$ and $75^{\text {th }}$ percentiles (lines) for our defined categories. The median SPT is seven years for the 456 projects that did not participate in a REEP and five years for the 156 projects where information on REEP participation is not known. Median SPT values are around six years for projects that participated in rebate programs, versus 3-4 years in DSM bidding and other SPC programs, not accounting for incentives. When incentives are included in the calculation, median SPT values are reduced by about one year for projects that participated in these programs. As noted in Chapter 3, because financial incentives were so lucrative in the initial phases of the NJSPC program, they have a dramatic impact on project economics for most customers. Median SPT decreases from $\sim 5$ years to $<1$ year for these 137 projects if we assume that customers received $50 \%$ of the reported financial incentives.

\footnotetext{
${ }^{28}$ See Chapter 6 for a more detailed explanation of REEP program types.

${ }^{29}$ The projects with "other" program types include projects for which the program type is unknown.
} 


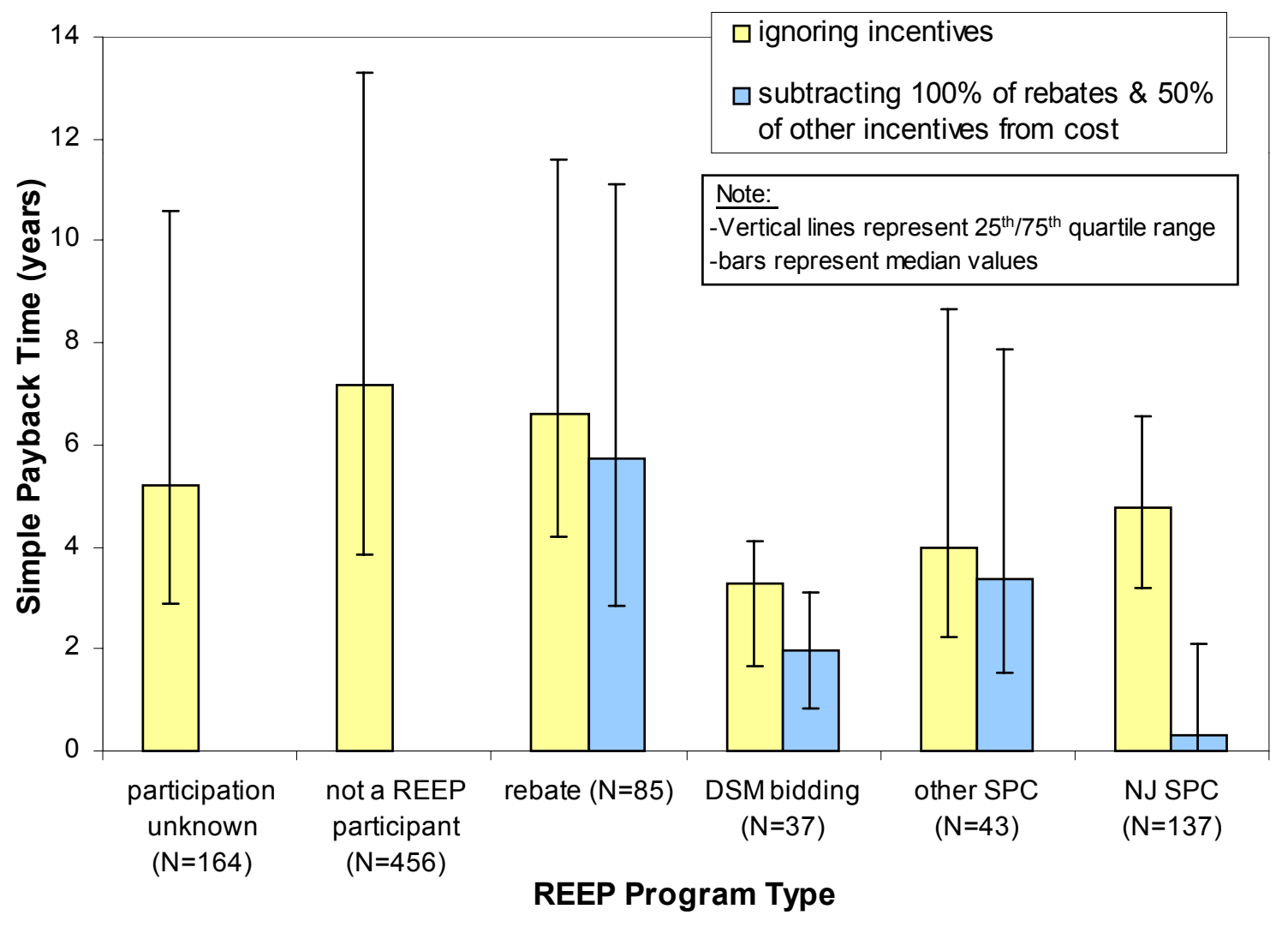

Figure 5-5. Impact of Ratepayer-Funded Energy-Efficiency Program Incentives on SPT 


\section{The Role of Enabling Policies and Programs}

\subsection{Summary}

- Policies and programs supported by state public utility commissions (e.g., energy-efficiency programs) and state/federal legislatures and agencies (e.g., enabling legislation and rules for performance contracting) have played an important role in stimulating ESCO activity in various markets.

- As part of our survey, ESCOs were requested to provide information on project participation in ratepayer-funded energy-efficiency programs (REEPs). Participation in REEPs by ESCOs has been decreasing in the last five years. From 1982-1995, 50\% of the projects in our sample were part of a REEP compared to $34 \%$ of the projects completed between 1996-2001.

- Projects that participated in a ratepayer-funded energy-efficiency program were classified into one of six program categories, and financial incentives received by the ESCO or customer were recorded. Standard Performance Contract (SPC) ${ }^{30}$, rebate, and DSM bidding were the most commonly reported types of energy-efficiency programs. Rebates were the most ubiquitous, reported for projects in 26 states. SPC programs were the largest in terms of financial incentives paid to ESCOs and number of customers. Projects participating in a REEP received $\sim \$ 310 \mathrm{M}$ of financial incentives or $58 \%$ of the costs of these projects. These incentives were used to offset or buy down costs of these projects, which is estimated at $\$ 532 \mathrm{M}$.

- Incentives provided in rebate, recent $\mathrm{SPC},{ }^{31}$ and DSM bidding programs were typically less than $50 \%$ of project costs. The median ratios of incentive levels to project costs were $12 \%$, $28 \%$ and $38 \%$ respectively for the three types of programs. However, financial incentives for most projects that participated in the New Jersey Standard Offer program significantly exceeded the cost to install the project. Differences in incentive levels between different REEP types (e.g., SPC vs. rebate programs) are related to the program's goals, design philosophy, utility's avoided costs of supply, and retail rates.

- State differences in performance-contracting activity in K-12 schools, university/colleges, and state/local government market segments are correlated with overall economic activity levels, favorable enabling legislation and/or procurement rules, and aggressive implementation and promotion by state energy agencies in charge of administering these activities. Examples of states with significant support for performance contracting include New York, Texas, New Jersey, Illinois, Pennsylvania and Wisconsin. More systematic collection of project data would enable states to demonstrate the effectiveness of their policies both in promoting private sector energy-efficiency services activity and in documenting the actual performance of projects.

\footnotetext{
${ }^{30}$ SPC and Standard Offer programs are essentially the same in terms of program design.

${ }^{31}$ Not including projects that were part of the New Jersey Standard Offer program.
} 


\subsection{Ratepayer-Funded Energy Efficiency Programs (REEPs)}

\subsubsection{Background and Methodology}

Historically, ESCOs have utilized and leveraged energy-efficiency programs funded either by utility ratepayers or system benefit charges in order to provide additional benefit to their customers as well as the utility system (e.g., avoiding or deferring the need for additional generation resources). Our sample of projects can be used to examine and illustrate the extent to which ESCOs have relied on ratepayer-funded energy-efficiency programs (REEPs) over time. We can also assess the financial impacts of these programs on project economics. Ultimately, policymakers are interested in the extent to which REEPs have succeeded in mitigating or overcoming market barriers so that customers in all markets have access to and opportunity to work with a robust, private sector energy-efficiency services industry.

ESCOs and state agencies were asked to indicate whether or not each project was part of a REEP. They were then asked to classify the programs into one of six categories:

- Rebate

- Loan

- DSM bidding

- SPC/ Standard offer

- Energy audit

- Design/technical assistance one-time payment/incentive offered for installation of energy efficient equipment market or below-market rate loans provided to finance projects quantity of electricity savings or demand reductions proposed by ESCOs for a specified price/incentive in response to a competitive solicitation; ESCOs are paid for savings at customer facilities based on a pay-for-performance approach standard contract and program guidelines that offer prespecified financial incentives to ESCOs for verified savings (pay-for-performance); "first-come, first serve" offer by program administrator until demand reduction goals or program budget limit is reached a customized audit of a customer's facility/buildings energy-efficiency program administrator provides technical assistance to customers on project design/development

If the program involved financial incentives (i.e., rebate, DSM bidding, SPC), ESCOs were also requested to provide the estimated value of the payments over the project lifetime (made to either the ESCO or customer).

Some ESCOs did not indicate whether or not the project participated in a REEP. ${ }^{32}$ In some cases, we were able to code this information for specific projects based on their date of completion, their geographic location and serving utility, the installed measures and the individual ESCO. For example, if the project was completed in a state that did not offer REEPs during that time, or if the ESCO was known not to have participated in those programs, the project was marked as not participating in a REEP. Projects that could not be coded in this way

\footnotetext{
32 The initial versions of the project survey form only asked for a positive response to this question (non-participants left the field blank), so many of the projects with blank or "unknown" responses are most likely not part of a REEP.
} 
were coded as "unknown," to distinguish them from projects that definitely did or did not participate in such programs.

\subsubsection{Program Participation}

Based on information provided by ESCOs and our analytical methods, we were able to determine the participation in REEP for about $83 \%$ of the projects in the database. About onethird of the projects completed prior to 1996 indicated that that they were developed without REEP assistance (see Figure 6-1). Since 1996, that fraction has increased to over one-half of the projects, which suggests that an increasing share of ESCO projects are now being developed without participation in a utility DSM or public purpose program. The decline in the share of projects participating in REEPs since 1996 could also be attributable to the overall decline in utility energy-efficiency program spending that has occurred nationally.

In interpreting these results, we note again that our sample of projects may not be representative of trends in the ESCO industry overall. However, we believe that our results represent an upper bound on ESCO reliance on and involvement in REEP because of the way in which our project data was collected. For example, several of the largest ESCOs in the industry that provided a small sample of their total projects have historically not been very active in utility energyefficiency programs. Moreover, several companies that have been heavily involved in utility DSM programs provided all of their projects.
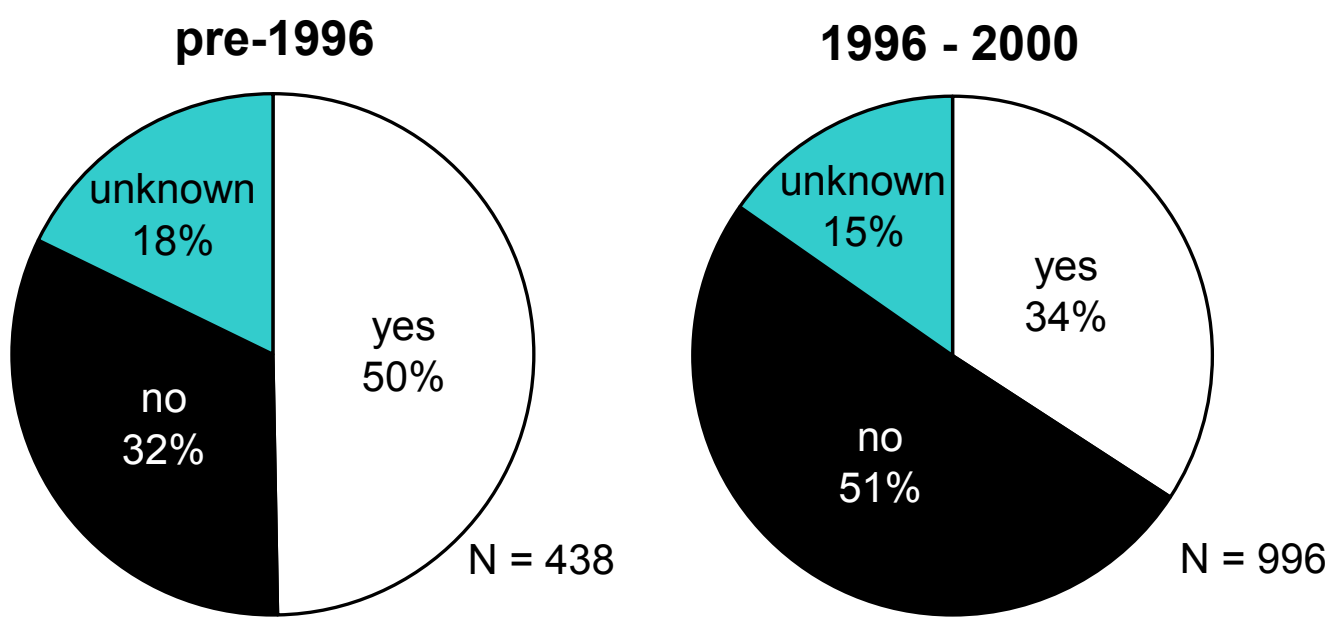

Figure 6-1. ESCO Project Participation Trends in Ratepayer Energy-Efficiency Programs

ESCOs reported participating in the following types of utility DSM programs: SPC (54\%), rebate (35\%) and DSM bidding (10\%). The SPC program participants were in the states of New Jersey, California and Texas. ${ }^{33}$ ESCOs reported that projects in 26 states and Canada participated in rebate programs for high-efficiency equipment. This diversity reflects the widespread use of rebate programs by utilities. Projects in eight states were part of DSM bidding programs, but most of these projects were located in California.

\footnotetext{
${ }^{33} 76 \%$ of SPC projects in the database are from the state of New Jersey.
} 
Figure 6-2 shows the number of projects participating in REEPs in each state. In our sample, the influence of these programs on ESCO activity is particularly pronounced in New Jersey with 176 projects, followed by California (66 projects), New York (38 projects) and Massachusetts (27 projects). Few projects in the Midwest, South, and Rocky Mountain regions were involved in REEP programs. In aggregate, the projects in our sample received a total of $\$ 310 \mathrm{M}$ in incentives from these programs, which is equal to $58 \%$ of the costs of these projects. These incentives were used to offset or buy-down costs of these projects. The total cost of the projects is estimated at $\$ 532 \mathrm{M}$.

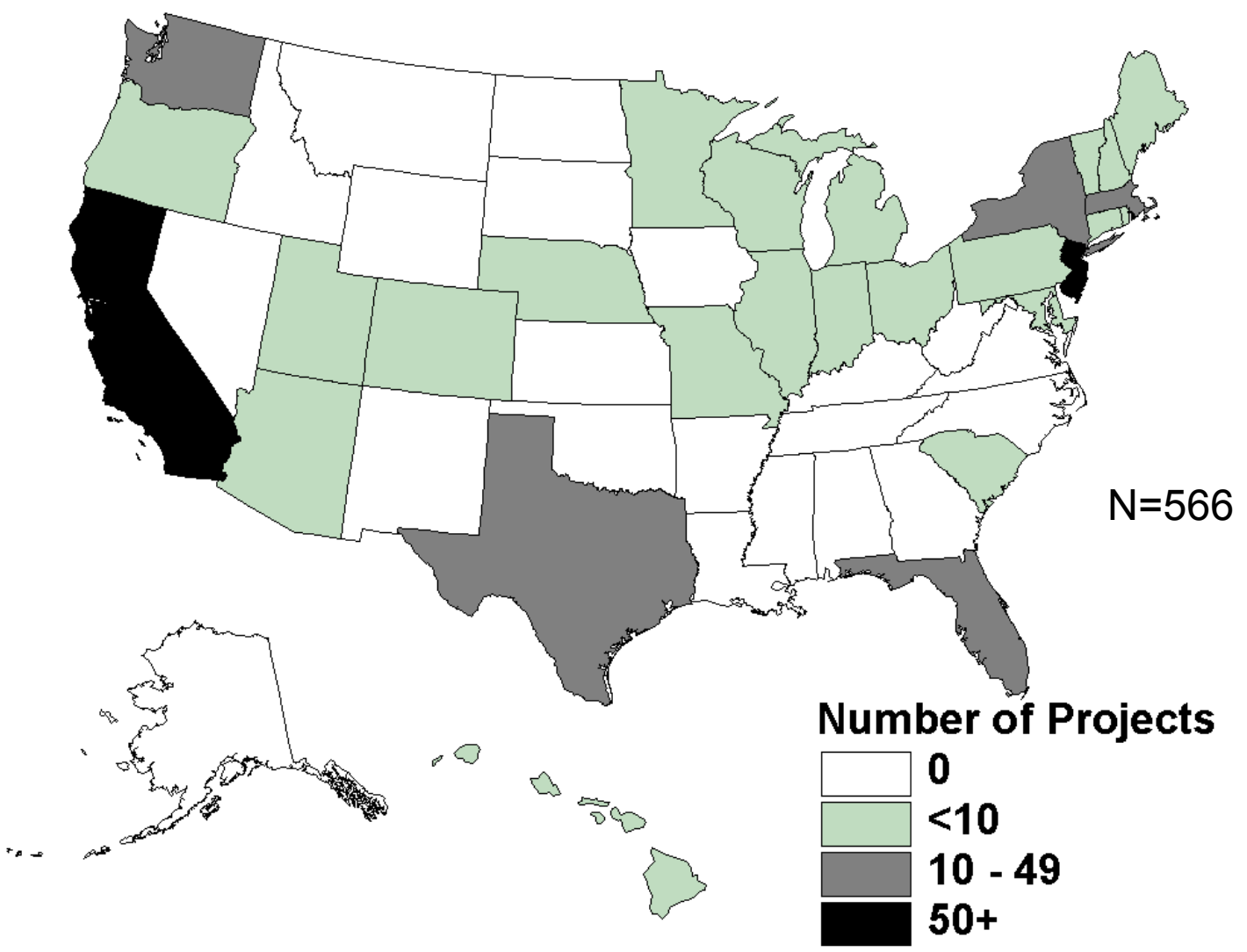

Figure 6-2. ESCO Project Participation in Ratepayer Energy-Efficiency Programs by State

\subsubsection{Impact of Financial Incentives}

Incentive levels vary significantly by type of program and among similar program types. Rebate programs are typically designed to reduce the first-cost barrier associated with the purchase and installation of new, high-efficiency equipment. In some cases, rebate incentive levels, particularly for more well-established, high-efficiency technologies, are set at levels sufficient to induce activity and/or overcome market barriers in specific market sectors by effectively buying down the customer's payback time. In general, incentives in rebate programs are more likely to be linked to incremental or total project costs. In contrast, DSM bidding and SPC programs often base their payments on the immediate demand reduction potential and its value (i.e., avoided cost) to the utility. 
The design and overall objectives of individual energy-efficiency programs are an important component in understanding the relationship between project cost, energy saved and incentive levels. For example, the New Jersey Standard Offer (NJSPC) program based incentives on the long-run avoided cost to the utility of installing new generation. Avoided costs were quite high at the time the program was offered in the early 1990s, which directly affected incentive levels. Subsequent SPC and DSM bidding programs in other states often capped their incentives at some fraction of project costs, to prevent payments in excess of the installed cost of the new equipment.

\subsubsection{Incentives vs. Project Costs}

Figure 6-3 shows the percent of project costs that are offset by incentives for various types of energy-efficiency programs: rebates, DSM bidding, NJ Standard Offer (NJSPC), and other SPC programs. Because our sample size varies by type of program (ranging from 37 to 138 projects), results are normalized and presented in percentage terms (i.e., the percent of projects for each type of program that received various incentive levels relative to project costs). We find that rebates typically offset much less of the total project costs associated with energy-efficiency retrofits than do SPC or DSM bidding programs. ${ }^{34}$ For the majority of projects, rebate programs refunded between $5 \%$ and $25 \%$ of total project costs, with a median of $12 \%$. The contribution of incentives in DSM bidding programs was higher, with incentives for most projects ranging from $25 \%$ to $55 \%$ of project costs. The majority of projects that participated in DSM bidding programs received less than $60 \%$ of total project costs back as incentives, although $\sim 20 \%$ of the projects received incentives that exceeded $100 \%$ of project costs $($ median $=38 \%)$.

The projects that participated in the New Jersey Standard Offer program were analyzed separately from SPC programs in Texas, California, New York, and Canada to highlight the impact of that program's specific design on incentive levels. About $84 \%$ of the projects that participated in the initial New Jersey Standard Offer program received incentives that exceeded total project costs (median $=188 \%$ ). These payments were based on utility forecasts of the avoided costs of installing new generation and were not directly linked to equipment or project costs. In contrast, less than $10 \%$ of projects in other SPC programs received incentives that exceeded their project costs. Three-quarters of the projects in these more recent SPC programs received incentives that were less than $50 \%$ of project costs with a median value of $28 \%$.

\footnotetext{
${ }^{34}$ ESCOs did not report information on incremental measure costs of the high-efficiency equipment compared to "current practice."
} 


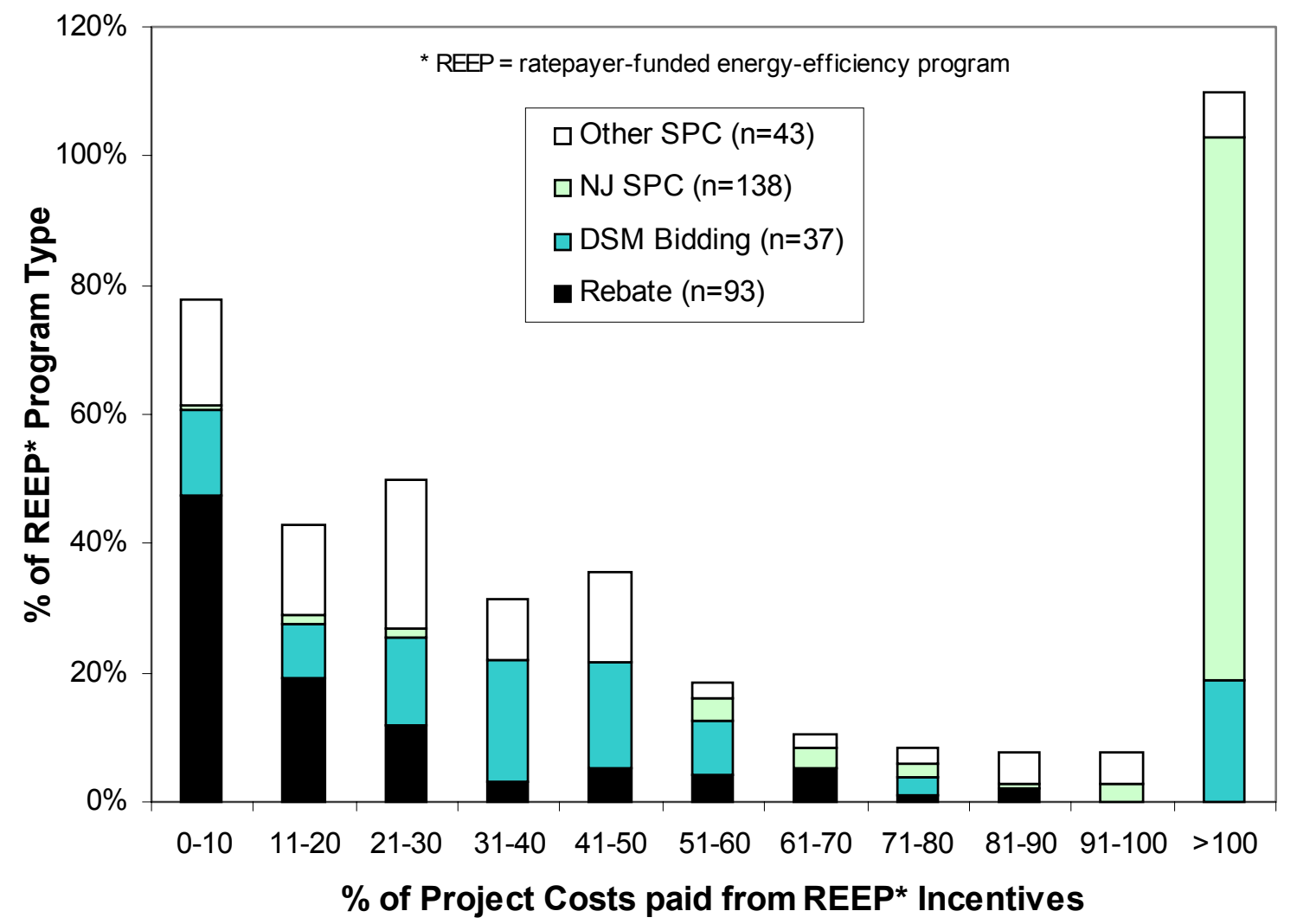

Figure 6-3. Fraction of Project Costs Paid from Ratepayer Energy-Efficiency Program Incentives

\subsubsection{ECMs Installed}

Program design can drive the types of ECMs that are installed. We analyzed the retrofit strategies utilized in projects that participated in various types of energy-efficiency programs (see Figure 6-4). We found that most projects that participated in DSM bidding and the NJSPC program pursued lighting only retrofit strategies ( $58 \%$ and $70 \%$ of projects respectively). During the early years of the NJSPC program, the measurement and verification (M\&V) protocols for some non-lighting measures had not been pre-specified. ESCOs wanting to install these measures had to negotiate M\&V protocols with the utility for specific projects; the utility then had to obtain approval from the regulatory commission. This process was time consuming and led many ESCOs to concentrate on high-efficiency lighting, for which M\&V protocols were well established. In contrast, the majority of projects that participated in rebate and other SPC programs pursued lighting and non-lighting retrofit strategies.

This same tendency emerges in our analysis of the number of energy-efficiency measures/strategies that were installed by projects that participated in various types of REEP programs (see Table 6-1). Using our approach of grouping individual ECMs into somewhat broader measure categories, we find that, on average, projects that took advantage of utility rebate programs had more measure categories than SPC programs: rebate programs (2.0), NJSPC (1.1), and other SPC programs (1.3). 


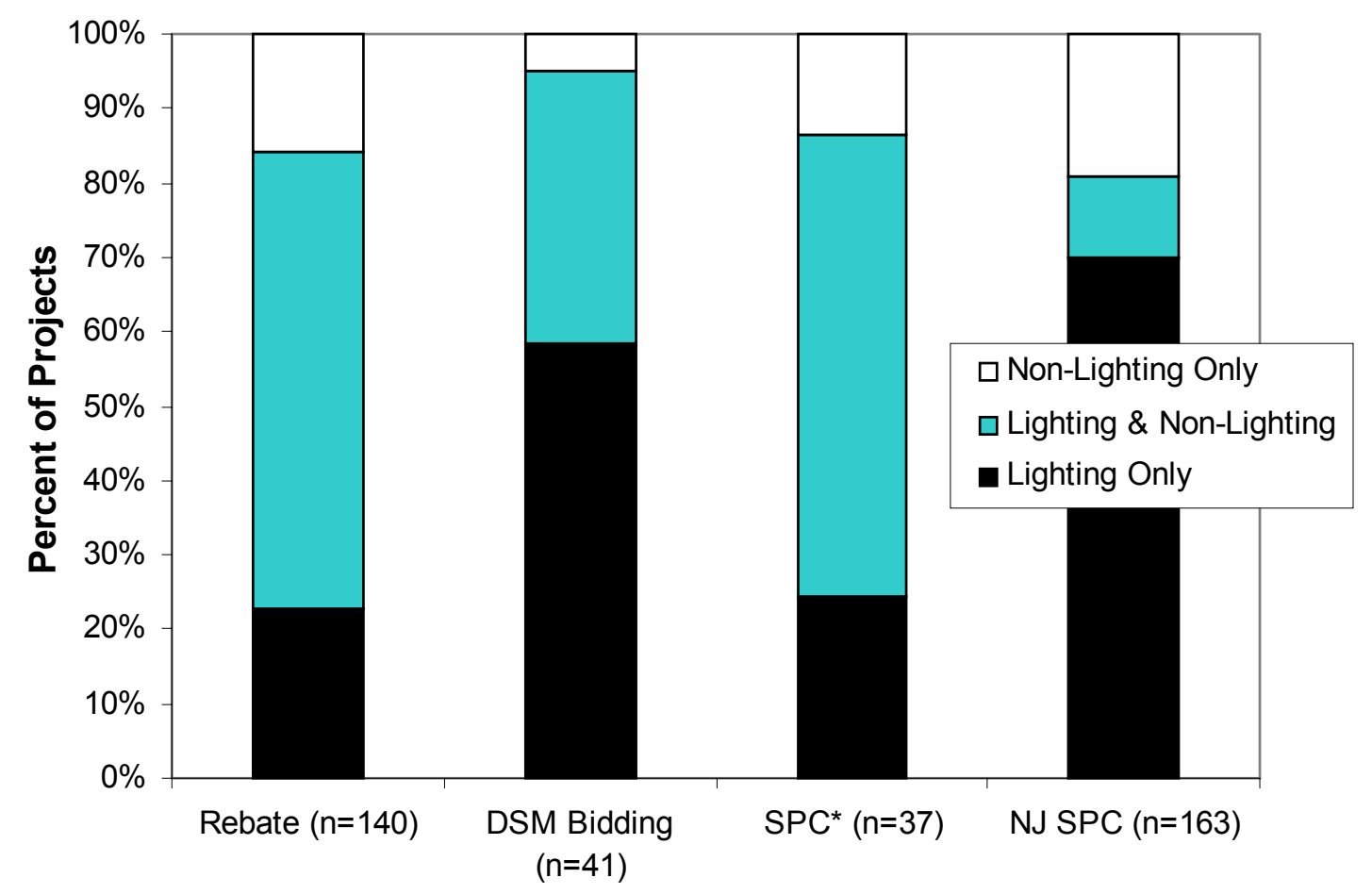

\section{Rate payer-Funded Energy-Efficiency Program Type \\ * excludes projects in New Jersey}

Figure 6-4. Retrofit Strategies Found in Various REEP Programs

Table 6-1. Measure Categories and Retrofit Strategies by REEP Program Type

\begin{tabular}{|c|c|c|}
\hline \multirow[t]{2}{*}{ DSM Program Type } & \multicolumn{2}{|c|}{$\begin{array}{c}\text { Number of } \\
\text { Measure Categories }\end{array}$} \\
\hline & $\mathrm{N}$ & average \\
\hline Rebate $(n=140)$ & 151 & 2.0 \\
\hline DSM Bidding $(n=41)$ & 41 & 1.7 \\
\hline $\operatorname{SPC}^{*}(n=37)$ & 62 & 1.3 \\
\hline NJ SPC $(n=163)$ & 172 & 1.1 \\
\hline
\end{tabular}

* excludes projects in New Jersey

\subsection{State Policies to Promote Performance Contracting}

Most states have enacted enabling policies or legislation to promote performance contracting or third party financing in their public sector institutional market (Donahue 2001: Energy Services Coalition 2001). The scope of these policies and programs varies by state and is typically defined in terms of the types of entities and facilities that are eligible to participate: K-12 schools, state/local government buildings, and university/colleges (UC). 


\subsubsection{Enabling Legislation for Institutional Markets}

Table 6-2 lists the market sectors included in state performance-contracting legislation. Of the 46 states that currently have such legislation, 39 states have targeted K-12 schools, 38 states include state/local government buildings, and 31 states include university/college facilities. The earliest programs started in the mid-1980s in Michigan, Ohio, Washington and New Jersey. Between 1988 and 1993, 10 more states enacted legislation specific to these institutional market segments. Since 1994, 32 states have added legislation to promote performance contracting in institutional buildings. Only Alaska, Rhode Island, Vermont, and Wyoming have not yet enacted legislation to cover these market segments. Many states have revised their initial legislation since its adoption, often broadening the type of public facilities or agencies that can participate.

Table 6-2. Summary of State Performance-Contracting Legislation

\begin{tabular}{|l|cl|}
\hline State & $\begin{array}{c}\text { Year } \\
\text { Enacted }\end{array}$ & Sector \\
\hline AK & n/a & NONE \\
AL & 1998 & ALL \\
AR & 1996 & SC, GO \\
AZ & 1996 & SC \\
CA & $*$ & ALL \\
CO & 1997 & SC, GO \\
CT & 1993 & ALL \\
DC & n/a & NONE \\
DE & $*$ & SC \\
FL & 1992 & ALL \\
GA & 1998 & SC \\
HI & 1997 & ALL \\
IA & $*$ & ALL \\
ID & $*$ & ALL \\
IL & 1994 & ALL \\
IN & 1997 & ALL \\
KS & 2000 & ALL \\
KY & 1996 & ALL \\
LA & 1988 & ALL \\
MA & 1997 & ALL \\
MD & 1997 & GO, UC \\
ME & 1993 & SC, GO \\
MI & 1984 & SC, GO \\
MN & 1989 & SC \\
MO & 1997 & GO, UC \\
\hline
\end{tabular}

\begin{tabular}{|l|cl|}
\hline State & $\begin{array}{c}\text { Year } \\
\text { Enacted }\end{array}$ & Sector \\
\hline MS & 1997 & ALL \\
MT & 1989 & SC \\
NC & 1996 & ALL \\
ND & $*$ & ALL \\
NE & 1998 & ALL \\
NH & 1996 & GO \\
NJ & 1986 & ALL \\
NM & 1993 & ALL \\
NV & 1993 & GO, UC \\
NY & 1997 & ALL \\
OH & 1985 & SC \\
OK & 1996 & SC \\
OR & 1997 & ALL \\
PA & 1998 & ALL \\
RI & n/a & NONE \\
SC & $*$ & ALL \\
SD & 1992 & ALL \\
TN & $*$ & ALL \\
TX & 1991 & ALL \\
UT & 1999 & GO \\
VA & 2001 & GO, UC \\
VT & n/a & NONE \\
WA & 1985 & ALL \\
WI & 1995 & GO \\
WV & $*$ & SC \\
WY & n/a & NONE \\
\hline & &
\end{tabular}

*Year unknown

** SC $=\mathrm{K}-12$ Schools, $\mathrm{GO}=$ state/local gov't, UC = university/colleges

sources:

Energy Services Coalition, www.escperfrom.org/legislation.htm

Patti Donahue, Donahue \& Associates

We hypothesize that ESCO activity in the public sector institutional market is influenced by the following factors: (1) the existence and scope of enabling legislation/policies, (2) the effectiveness of specific program rules and/or guidelines included in the legislation or adopted 
by the administering state agency, (3) the level of resources, effort and enthusiasm of state agencies responsible for administering these activities, (4) the existence and effectiveness of complementary policies such as REEPs and (5) other fundamental market drivers, such as market size and potential, electricity and gas rates, and capital budgets of public agencies.

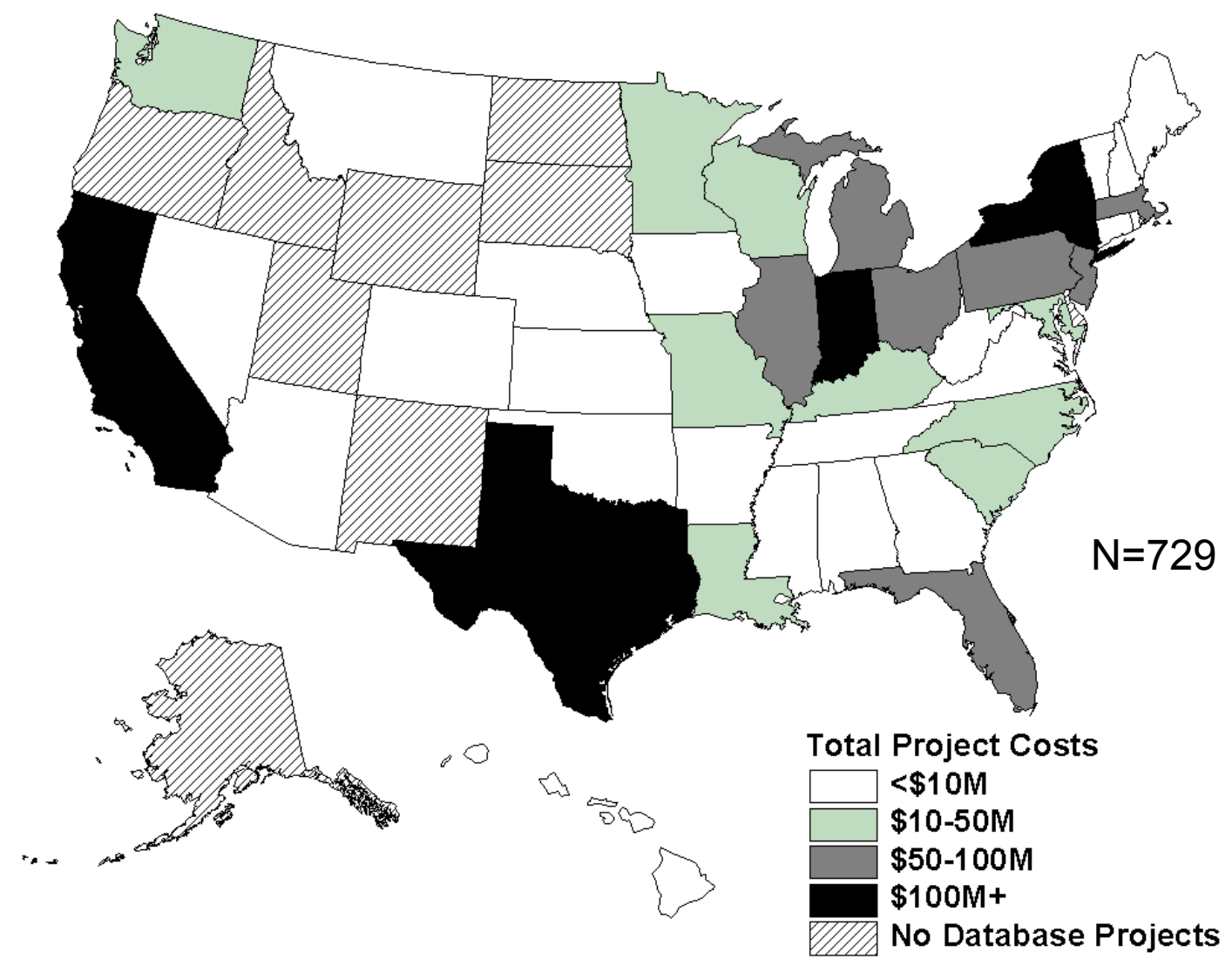

\section{Figure 6-5. State Project Activity in K-12 Schools, Local/State Governments and University/Colleges}

Our database of ESCO projects can be used to provide some insights into the impact of enabling policies adopted by individual states in public sector buildings. ${ }^{35}$ Figure 6-5 shows aggregate project activity in these three market segments by state, expressed in terms of project costs. Four states (New York, California, Texas and Indiana) report the most activity $(>\$ 100 \mathrm{M})$ in these three institutional markets. New Jersey, Illinois, Ohio, Massachusetts, Florida, Pennsylvania and Michigan report ESCO activity in the $\$ 50-100 \mathrm{M}$ range. Five of these seven states have enacted enabling policies that encourage performance contracting in all three institutional market segments. Ohio and Michigan have enacted legislation for one (K-12 schools) and two (K-12 schools and state/local government) institutional market segments, respectively. Kentucky, Missouri and Washington report a high number of projects, but total project costs are between $\$ 10 \mathrm{M}$ and $\$ 50 \mathrm{M}$ in each of these states.

\footnotetext{
${ }^{35}$ About $75 \%$ of the project data in these three market segments were provided directly by ESCOs and provide a way to gauge market activity independently; $25 \%$ was provided by eight state agencies.
} 
Louisiana, Maine, Montana, New Mexico, Nevada, and South Dakota are states with longstanding enabling legislation (from 1988 to 1993), but with only a few projects reported in the database. The smaller, more dispersed market in these states or the use of local as opposed to regional or national contractors may explain this low representation. For many states, it is not yet possible to determine the effectiveness of legislation and procurement programs. More systematic collection and contribution of project data will enable states to demonstrate the effectiveness of their policies both in promoting private sector energy-efficiency services activity and in documenting the actual performance of projects.

\subsubsection{Factors Affecting ESCO Market Activity}

We conducted exploratory analysis to assess the relative importance of state energy office activity and the degree to which enabling legislation affects ESCO market activity in individual states. Table 6-3 shows the 20 states with the highest ESCO project costs reported in the database. We then ranked states in terms of their economic activity as indicated by gross state product, or GSP, state energy office activity, ${ }^{36}$ number of institutional sectors targeted by enabling legislation, and overall promotional ranking. ${ }^{37}$

Eight of the top 10 states in terms of ESCO project activity also ranked in the top 10 for economic activity. This result underscores the reality that ESCOs tend to be most active in states with large markets. Favorable performance-contracting legislation may have the most impact in states with medium to smaller size institutional markets. For example, Indiana and Kentucky's legislation includes all three institutional market sectors. In our sample of projects, Indiana ranks fourth highest in ESCO market activity and is ranked $15^{\text {th }}$ in overall economic activity. Similarly, Kentucky is ranked $14^{\text {th }}$ in ESCO market activity and has a large number of ESCO projects, although it is ranked only $26^{\text {th }}$ in overall economic activity. Only three states in the top 10 list of ESCO project activity ranked somewhat low in terms of state energy office activity. Ohio is the only state in the top 10 in terms of ESCO market activity that has a more limited scope in its enabling legislation, only including K-12 schools.

It was more difficult to gauge the relative impact of state energy office or agency activity levels. For example, our survey of several industry experts indicated that state energy offices in Delaware, Colorado, Maryland, and Washington were quite active in promoting ESCOs or performance-contracting activity. Of these states, Maryland and Washington ranked in the top 20 in ESCO market activity and in overall economic activity. In the future, we intend to target data collection efforts at state agencies that administer these performance-contracting programs in order to examine the relationship between ESCO activity levels, enabling legislation, and program implementation more closely.

\footnotetext{
${ }^{36}$ We surveyed several industry experts and asked them to categorize the activity level of state energy offices or the office responsible for administering performance-contracting programs in the institutional market. Activity level was ranked on a scale of 1 to 3 ( 1 = low activity, 3 = high activity).

${ }^{37}$ We combined the activity of state energy offices and number of institutional sectors covered by enabling legislation into a single metric (calculated as "State Energy Office Activity" level multiplied by the "Number of Sectors with Legislation").
} 
Table 6-3. ESCO Institutional Market Activity and State Promotion of Performance Contracting

\begin{tabular}{|c|c|c|c|c|c|c|c|c|}
\hline \multirow[t]{2}{*}{ State } & \multicolumn{3}{|c|}{$\begin{array}{l}\text { ESCO Project Costs } \\
\qquad(\mathrm{SC}, \text { UC \& GO) }\end{array}$} & \multicolumn{2}{|c|}{$\begin{array}{l}\text { Economic Activity } \\
\text { (1999 GSP)* }\end{array}$} & \multirow{2}{*}{\begin{tabular}{|c|}
$\begin{array}{c}\text { State Energy } \\
\text { Office Activity }\end{array}$ \\
1=low, $2=$ medium, \\
3=high ${ }^{* *}$
\end{tabular}} & \multirow{2}{*}{$\begin{array}{l}\text { Number of } \\
\text { Sectors } \\
\text { with } \\
\text { Legislation }\end{array}$} & \multirow{2}{*}{$\begin{array}{l}\text { LBNL Overall } \\
\text { Rating }^{* * *} \text { of State } \\
\text { Support for } \\
\text { Perf. Contracting }\end{array}$} \\
\hline & $\operatorname{Rank}^{\dagger}$ & $(\$ M)$ & $\mathrm{N}$ & $\operatorname{Rank}^{\dagger}$ & (\$B) & & & \\
\hline New York & 1 & 287 & 76 & 2 & 755 & 2.3 & 3 & 7 \\
\hline California & 2 & 147 & 81 & 1 & 1229 & 1.0 & 3 & 3 \\
\hline Texas & 3 & 131 & 40 & 3 & 687 & 2.0 & 3 & 6 \\
\hline Indiana & 4 & 112 & 23 & 15 & 182 & 1.0 & 3 & 3 \\
\hline New Jersey & 5 & 84 & 95 & 8 & 332 & 2.0 & 3 & 6 \\
\hline Illinois & 6 & 75 & 38 & 4 & 446 & 2.0 & 3 & 6 \\
\hline Ohio & 7 & 68 & 45 & 7 & 362 & 2.0 & 1 & 2 \\
\hline Massachusetts & 8 & 66 & 27 & 11 & 263 & 1.7 & 3 & 5 \\
\hline Florida & 9 & 65 & 23 & 5 & 443 & 1.0 & 3 & 3 \\
\hline Pennsylvania & 10 & 54 & 37 & 6 & 383 & 2.0 & 3 & 6 \\
\hline Michigan & 11 & 53 & 39 & 9 & 308 & 2.0 & 2 & 4 \\
\hline Wisconsin & 12 & 43 & 9 & 20 & 166 & 2.5 & 3 & 8 \\
\hline Missouri & 13 & 33 & 13 & 18 & 170 & 1.0 & 2 & 2 \\
\hline Kentucky & 14 & 31 & 36 & 26 & 114 & 2.0 & 3 & 6 \\
\hline Louisiana & 15 & 23 & 4 & 24 & 129 & $\mathrm{n} / \mathrm{a}$ & 3 & $\mathrm{n} / \mathrm{a}$ \\
\hline South Carolina & 16 & 17 & 5 & 28 & 107 & $\mathrm{n} / \mathrm{a}$ & 3 & $\mathrm{n} / \mathrm{a}$ \\
\hline Minnesota & 17 & 16 & 7 & 17 & 173 & 1.5 & 1 & 2 \\
\hline Maryland & 18 & 16 & 4 & 16 & 175 & 3.0 & 2 & 6 \\
\hline North Carolina & 19 & 12 & 6 & 12 & 259 & 1.0 & 3 & 3 \\
\hline Washington & 20 & 10 & 13 & 14 & 209 & 3.0 & 3 & 9 \\
\hline
\end{tabular}

‡SC = K-12 schools, UC = university/colleges, GO = state/local gov't

${ }^{\dagger}$ Ranking amoung the 50 U.S. states; $1=$ highest, $50=$ lowest.

Sources:

* Bureau of Economic Analysis. Regional Accounts Data: Gross State Product Data.

** Values are averages of responses in a blind survey of several industry experts.

*** Calculated as "State Energy Office Activity" level multiplied by the "Number of Sectors with Legislation."

n/a State not ranked by survey participants. 


\section{Analysis of Aggregate ESCO Industry Activity}

\subsection{Summary}

- We estimate the size of the ESCO industry from 1990-2000 based on information collected from 63 companies, including phone interviews and mail surveys with 20 ESCOs that are NAESCO members and information provided by industry experts for other companies that offer performance contracting as a core part of their business.

- We estimate that ESCO industry revenues for energy-efficiency related services range from $\$ 1.8-2.1 \mathrm{~B}$ in 2000 and that industry revenues have increased at an average annual growth rate of $24 \%$ during the last decade. However, from 1996 to 2000, growth rates have decreased somewhat, averaging about $9 \%$ per year. Thirteen companies account for about $75 \%$ of total ESCO industry activity.

- We estimate that the performance-contracting share of total ESCO market activity has decreased from $74 \%$ in $1990-95$ to $57 \%$ in $1996-2000$. The size of the performancecontracting market ranges between $\$ 0.9-1.0 \mathrm{~B}$ in 2000 . These results suggest that performance contracting may not be the primary source of future growth for the ESCO industry, but rather that revenue growth may hinge on successful development of other valueadded services that build on ESCO core competencies.

- Projects in the database represent about $15 \%$ of total industry activity during the 1990-2000 period, although our data collection methods mean that certain types of projects, market segments, and industry providers may be over- or under-represented compared to overall industry activity.

\subsection{Background}

Several previous studies have characterized the market for energy efficiency or energy services and estimated industry activity or market potential. Different sampling methods and definitions of industry scope have been used, with dramatically different results. Cudahy and Dreessen (1996), working on behalf of NAESCO, developed estimates of ESCO performance-contracting activity based on interviews with NAESCO members and their expert judgment. Easton Management Consultants and Feldman (1999) examined trends in the ESCO industry in two states (New York and Wisconsin). As part of that study, they used data on the number of field offices maintained by ESCOs coupled with their estimates of annual revenue required to support field offices in order to develop an extrapolation of ESCO industry activity. Frost and Sullivan (1997), a market research firm, characterized and estimated potential for the market for Energy Management Services. Their estimates included equipment sales, financing, O\&M contracting, and other energy-related markets and thus define the market of interest in much broader terms than our study.

A challenging aspect of this exercise is defining the ESCO market in a way that reflects industry evolution. ESCOs and other entities that provide energy-efficiency services (e.g., contractors, consulting firms) all offer a variety of energy-efficiency related services. Historically, a distinguishing feature of ESCOs compared to other entities has been their reliance on 
performance contracting as a key business activity. ESCOs also offer other services or products, such as design/build services on a fee-for-service basis, energy consulting, and other performance-based arrangements (e.g., build/own/operate major energy facilities). The mix of performance contracting and other value-added services varies by ESCO. With the advent of electricity restructuring, some ESCOs and retail energy service companies (RESCOs) have attempted to bundle offers to customers that involve procurement of electricity and gas commodity, risk management products, and energy-efficiency services.

In estimating ESCO market activity, we decided to focus on energy-efficiency related and other value-added services and have excluded revenues from electric or gas commodity procurement. To that end, we surveyed companies that offer performance contracting as a core part of their energy-efficiency services business. We collected information on total project costs (or company revenues) during the 1990-2000 time frame for each company and asked ESCOs to estimate the fraction of total activity that involved performance contracting versus other types of energy-efficiency services (e.g., design/build, fee-for-service, build/own/operate).

\subsection{Methods}

We identified and surveyed 63 companies that have national or regional operations in the energyefficiency services industry. Companies that do not offer performance contracting were excluded from our survey, but companies that were included did not have to offer performance contracting exclusively. Appendix $\mathbf{E}$ lists the companies that were part of our survey, distinguished as NAESCO and non-NAESCO members. Companies that have merged are listed only under the current company name; business activity from acquired companies is included in the project costs or revenues of the current company.

A diverse set of sources was used to develop information on ESCO industry market activity. When possible, we interviewed companies directly $(\mathrm{N}=14)$. We also received financial information from request for qualifications (RFQ) issued by state agencies interested in hiring performance contractors, and from company financial statements $(\mathrm{N}=17)$. Company overviews comprising general descriptions of various business lines that were submitted with the NAESCO accreditation application were also consulted $(\mathrm{N}=6)$. When these sources were not available to us, we surveyed industry experts through a modified delphi approach in order to develop estimates of individual company market activity $(\mathrm{N}=26)$. As part of this survey, companies were classified into size categories based on annual project costs or revenues (see Table 7-1).

Table 7-1. Company Size Definitions for Aggregate Activity Survey

\begin{tabular}{|l|l|}
\hline Classification & Annual Revenues \\
\hline Small & Less than $\$ 5 \mathrm{M}$ \\
\hline Medium & $\$ 5 \mathrm{M}-\$ 30 \mathrm{M}$ \\
\hline Large & More than $\$ 30 \mathrm{M}$ \\
\hline
\end{tabular}

Our survey of ESCOs requested information on the total number of projects completed, annual project costs over time, activity level by market segment, the extent of reliance on ratepayerfunded energy-efficiency programs, and the performance-contracting share of total business. 
For those companies where a delphi approach was used or for companies with periods of missing data (e.g., pre-1996 period), we included low and high values of their market activity based on a range of values given by our industry experts.

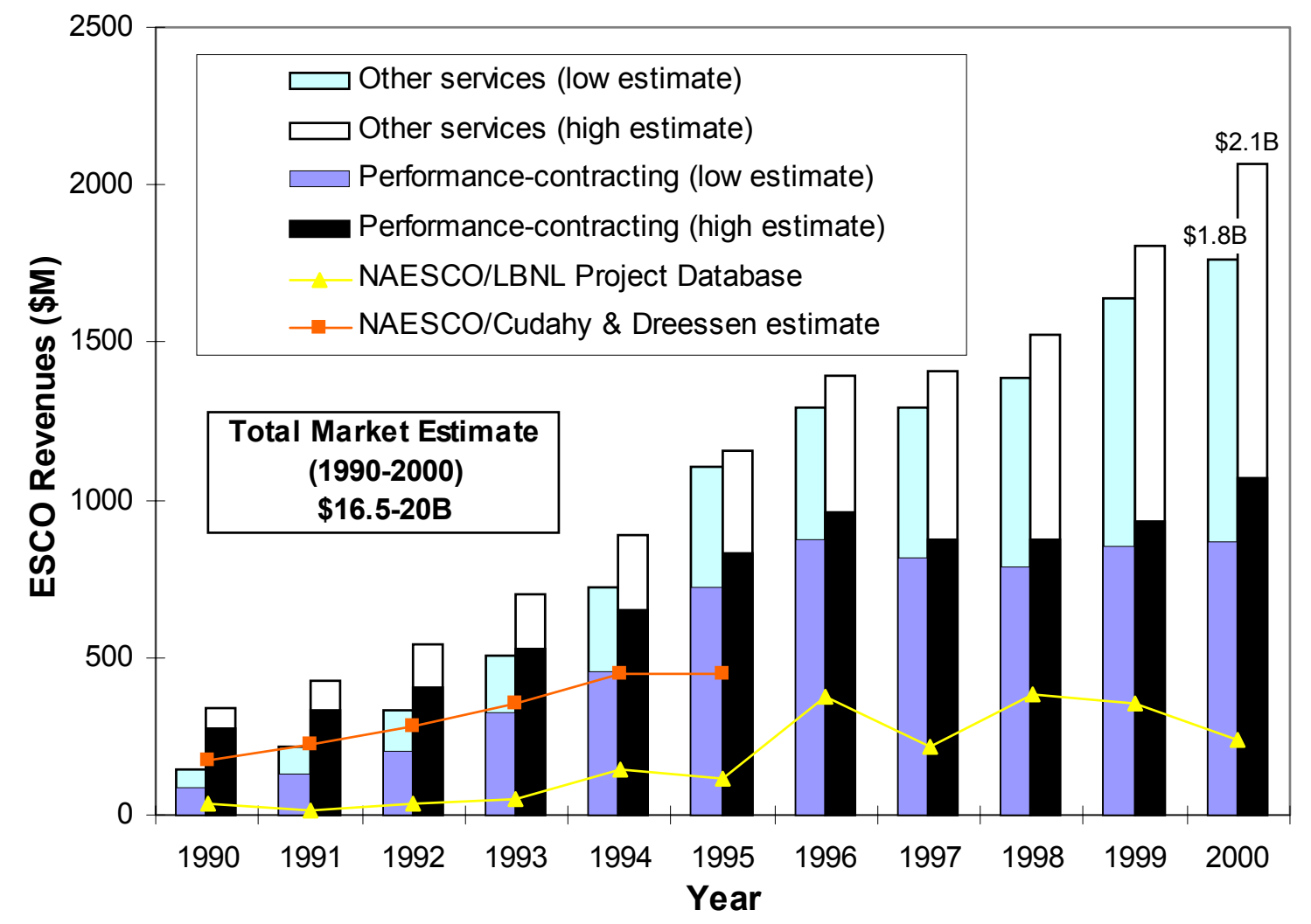

Figure 7-1. Market Activity: ESCO Project Revenues by Source

\subsection{Results}

\subsubsection{Market Activity}

Figure 7-1 shows our low and high estimates of ESCO industry activity between 1990 and 2000. As of 2000, we estimate that ESCO market activity for various energy-efficiency related services ranges between $\$ 1.8 \mathrm{~B}$ and $\$ 2.1 \mathrm{~B}$ annually. The industry experienced rapid growth during the last decade with aggregate project costs (revenues) increasing at an annual rate of $24 \%$ during the 1990-2000 period. However, since 1996, industry growth rates have decreased somewhat, averaging about $9 \%$ during the 1996-2000 period. Factors that may explain slower growth rates during the 1996-2000 period include the relative maturity and saturation of performance contracting in traditional institutional markets, the upheaval and uncertainties created by electricity restructuring and retail competition in various states, reduced spending on REEP programs, and increased competition from new entrants such as retail energy service companies. We also estimate that the performance-contracting share of total ESCO market activity has decreased from $74 \%$ to $60 \%$ during the $1990-95$ and $1996-2000$ time periods. Based on our analysis, the size of the performance-contracting market ranges between $\$ 0.9 \mathrm{~B}$ and $\$ 1.0 \mathrm{~B}$ in 2000. These results suggest that performance contracting may not be the primary source of 
future growth for the ESCO industry, but rather that future revenue growth may hinge on successful development of other value-added services that build on ESCO core competencies.

For comparison purposes, we include Cudahy and Dreessen's (1996) estimate of the size of the performance-contracting industry as well as total annual project costs in the NAESCO/LBNL database in Figure 7-1. Our low estimate of the size of the performance-contracting market agrees closely with Cudahy \& Dreessen's estimate for the 1990-1995 period. It is also apparent that the NAESCO/LBNL database represents about $15-20 \%$ of ESCO industry activity in the 1996-2000 period, with lower representation during the pre-95 period.

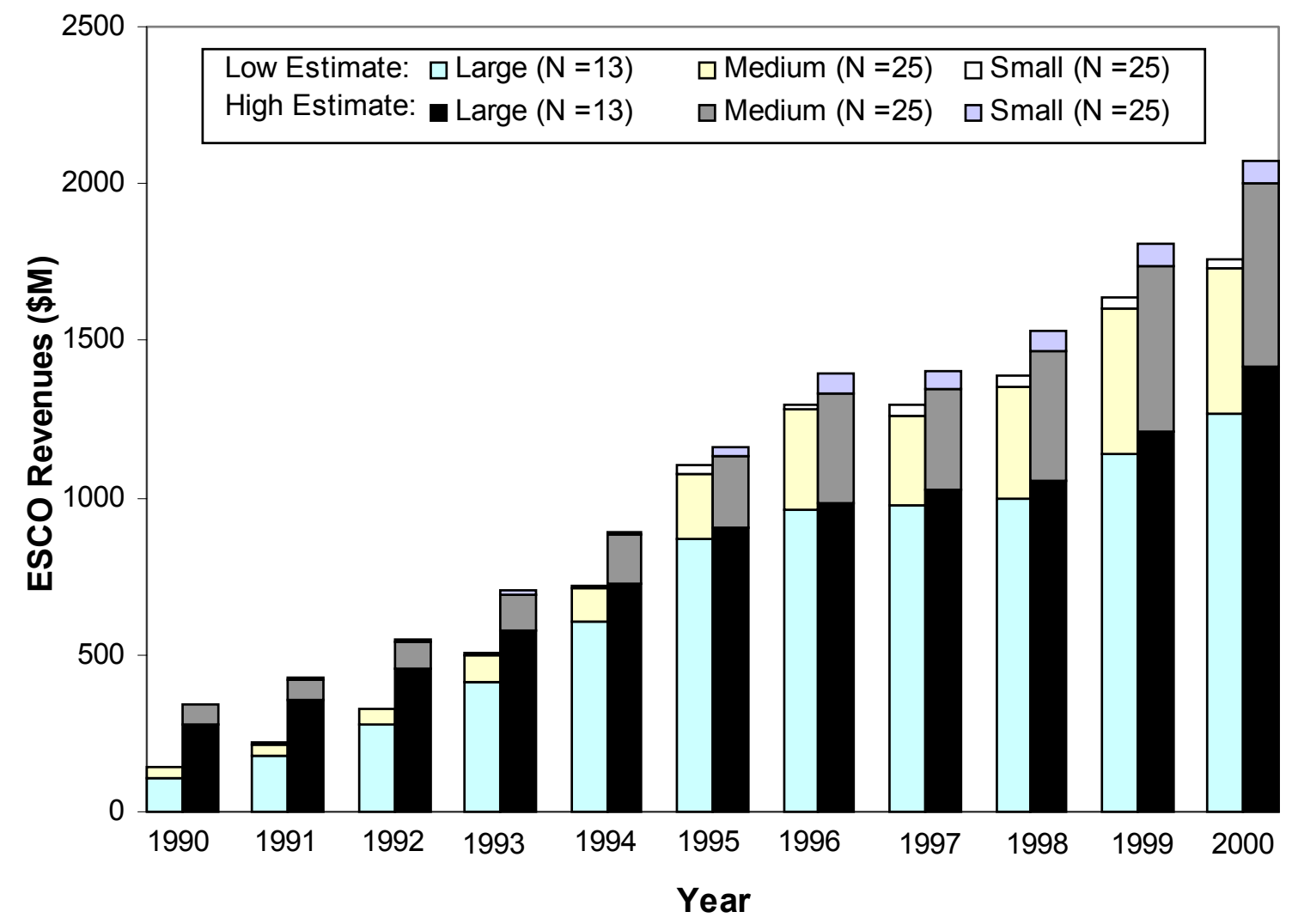

Figure 7-2. Aggregate Industry Activity by Company Size

We also found that 13 companies with annual revenues over $\$ 30 \mathrm{M}$ account for about $75 \%$ of total ESCO industry activity and that the relative market share of major players has not changed significantly over time (see Figure 7-2). This trend is noteworthy given the number of mergers and acquisitions within the industry during this same time period. In aggregate, medium-sized companies (annual revenues of \$5-30M) have increased their share of the total ESCO market in recent years. This may be a result of our approach used to characterize market activity from our survey of industry experts (i.e., company size categories), but may also reflect increased market entry and market share by new players (mainly utility-owned ESCOs) with the onset of electricity restructuring. NAESCO members and affiliate companies represent about $98 \%$ of total ESCO industry activity from 1991 to 1995 , and have accounted for $92 \%$ of total ESCO industry activity in the 1996-2000 period. 


\subsubsection{How Representative are Database Projects of Overall ESCO Market Activity?}

We interviewed twenty companies that provided database projects in order to explore issues related to the representative-ness of our samples compared to their overall market activity. Survey questions covered the following topics: (1) percent of their total market activity in each year represented by their sample of projects, (2) market segment breakdown of sample projects compared to their overall market activity (e.g., over- or under-representation of certain market segments in their sample), (3) relative share of performance contracting and other types of arrangements in their sample of projects vs. their total market activity, and (4) percent of sample projects that participated in REEPs compared to their total market activity.

For these 20 companies ( 8 large, 11 medium, 1 small), we found that our database projects accounted for about 15\% of their total market activity from 1990-2000 (21\% since 1996 and $11 \%$ from 1990-1995). These 20 companies accounted for $45-50 \%$ of total industry activity during the 1991-1995 period and 20\% from 1996 to 2000 .

\subsubsection{Future Work}

Because ESCOs self-report data, we expect that the majority of our projects are examples of successful energy-efficiency retrofit projects. Based on company responses and our assessment of the limitations of the data collection methodology, we developed a list of key areas that we believe are either under- or over-represented in our project sample compared to overall ESCO market activity (see Table 7-2). In the future, we intend to target data collection efforts in order to ensure that projects in the database are representative of overall industry activity to the extent feasible. In particular, we intend to target our efforts on projects completed in the private sector, to contact non-NAESCO member ESCOs to increase their participation, and to encourage large ESCOs to report a greater fraction of their total projects. We also plan to work with public housing authorities to incorporate more projects from this market segment.

\section{Table 7-2. Potential Biases of Data Collection Methodology}

\section{Project Type or Market Area}

\begin{tabular}{|l|l|}
\hline Public, institutional sector projects & Over represented \\
\hline NAESCO member projects & Over represented \\
\hline Projects that utilized REEP funds/incentives & Over represented \\
\hline Performance-contracting projects & Over represented \\
\hline $\begin{array}{l}\text { Residential/Public Housing Authority } \\
\text { projects }\end{array}$ & Under represented \\
\hline $\begin{array}{l}\text { Projects for private sector customers (e.g., } \\
\text { industry, commercial office, retail) }\end{array}$ & Under represented \\
\hline
\end{tabular}




\section{Conclusions}

This report summarizes industry and market trends in the energy-efficiency services industry based on a bottom-up analysis of $\sim 1500$ projects. We have tried to demonstrate the value of compiling and analyzing project-specific information on the ESCO industry using standardized methods in order to provide useful information to policymakers and market actors alike. In undertaking such an effort, we are cognizant of limitations imposed by our data collection methods (e.g., project selection bias), inconsistent ESCO tracking and reporting practices of ESCOs, and uneven quality of project data. We have adopted various quality assurance and controls to improve data quality and consistency and reached out to other data sources (e.g., state energy offices) to minimize self-selection bias.

The NAESCO/LBNL database project is an ongoing initiative, which provides a unique, public domain information source on industry trends, market activity and business practices of companies involved in energy-efficiency related services. Our intent is to expand and refine the project database and industry/market analysis reports in order to address emerging information needs of policymakers, market actors, and customers. 


\section{References}

American Council for an Energy Efficient Economy (ACEEE). 2001. Summary Table of Public Benefit Programs and Electric Utility Restructuring. http://www.aceee.org/briefs/mktabl.htm

Birr, Dave. 2002. Personal Communication. February 12.

Bureau of Economic Analysis. 2001. National accounts data NIPA Table 7.1: Quantity and price indices for gross domestic product. http://www.bea.doc.gov/bea/dn1.htm

Bureau of Economic Analysis. 2001. Regional Accounts Data: Gross State Product Data. http://www.bea.doc.gov/bea/regional/gsp/

California Energy Commission (CEC). 1995. Database for Energy-efficiency Resources. http://www.energy.ca.gov/forecasting/DEER.html

Cudahy, Richard D. and Thomas K. Dreessen. 1996. A review of the energy service company (ESCO) industry in the United States. NAESCO for the World Bank. March.

Dayton, Dave, Charles Goldman, and Steven J. Pickle. 1998. "The Energy Services Company Industry: Analysis of Industry and Market Trends," ACEEE. August.

Donahue \& Associates, Inc. 1998. Energy performance contracting in Florida, Volume I. Florida Energy Office, September.

Donahue, Patti. 2001. Personal Communication.

Easton Management Consultants and Shel Feldman 1999."ESCO Market Research Study,” prepared for Energy Center of Wisconsin and NYSERDA.

Edgar, George R., Martin Kushler, Don Schultz. 1998. Evaluation of Public Service Electric \& Gas Company's standard offer program. Wisconsin Energy Conservation Corporation for Public Service Electric \& Gas Company. October.

Energy Information Administration. 1988. Electric Power Annual. DOE/EIA-0348 (87).

Energy Information Administration. 1988. Typical Electric Bills. DOE/EIA-0040 (88).

Energy Information Administration. 1990. Electric Power Annual. DOE/EIA-0348 (89).

Energy Information Administration. 1991. Electric Power Annual. DOE/EIA-0348 (90).

Energy Information Administration. 1993. Electric Power Annual. DOE/EIA-0348 (92). 
Energy Information Administration. 1994. Electric Power Annual 1993, Volume II. DOE/EIA0348 (93).

Energy Information Administration. 1996. Electric Power Annual 1995, Volume II. DOE/EIA0348 (95). December.

Energy Information Administration. 1998. Electric Power Annual 1997, Volume II. DOE/EIA0348 (97). October.

Energy Information Administration. 1999. Annual Electric Utility Data - EIA-861 Data File.

Energy Information Administration. 2000. Annual Energy Outlook 2001: With projections to 2020. DOE/EIA-0383(2001). December.

Energy Information Administration. 2000. Annual Energy Review 1999. DOE/EIA-0384 (99). July.

Energy Information Administration. 2000. Annual Energy Review 2000. Table 8.13. DOE/EIA0383(00). December.

Energy Information Administration. 2000. Coal Industry Annual 1999. DOE/EIA-0584 (99).

Energy Information Administration. 2000. EIA-861: Schedule V. http://www.eia.doe.gov/cneaf/electricity/page/eia861dsm.html

Energy Information Administration. 2000. Electric Power Annual 1999, Volume II. DOE/EIA$0348(99) / 2$. August.

Energy Information Administration. 2000. Historical Natural Gas Annual, 1930 through 1999. DOE/EIA-0110 (99). October.

Energy Information Administration. 2000. U.S. Electric Utility Demand-Side Management. Table 23. DOE/EIA-.

Energy Information Administration. 2001. Electric Power Monthly, DOE/EIA-0226 (2001/03). March.

Energy Information Administration. 2001. Natural Gas Monthly. DOE/EIA-0130 (2001/06). June.

Energy Services Coalition. 2001. www.escperform.org.

Ernst \& Young. 1986. 1986 National Water and Wastewater Rate Survey: Exhibit I. Washington, D.C. 
Ernst \& Young. 1990. 1990 National Water and Wastewater Rate Survey: Exhibit I. Washington, D.C.

Ernst \& Young. 1992. 1992 National Water and Wastewater Rate Survey: Exhibit I. Washington, D.C.

Ernst \& Young. 1994. 1994 National Water and Wastewater Rate Survey: Exhibit I. Washington, D.C.

Ernst \& Young. 1996. 1996 National Water and Wastewater Rate Survey: Exhibit I. Washington, D.C.

Frost and Sullivan, 1997. North American markets for non-residential energy management services. Frost \& Sullivan, California.

Goldman, C. and D. Dayton 1996. "Future Prospects for ESCOs in a Restructured Electricity Industry." Proceedings: 1996 ACEEE Summer Study on Energy Efficiency in Buildings, 10.59-69. Washington, D.C.: American Council for an Energy-Efficient Economy.

Goldman, C.A., P. Juergens, M. Fowlie, J. Osborn, K. Kawamoto, T. Singer. 2000. Historical performance of the U.S. ESCO industry: Results from the NAESCO project database. ACEEE. August.

Koomey, Jonathan, Arthur H. Rosenfeld, and Ashok Gadgil. 1989. Conservation screening curves to compare efficiency investments to power plants. LBNL-27286. October.

National Association of Energy Services Companies (NAESCO). 2000. Accreditation application for NAESCO members. NAESCO.

National Association of State Energy Officials (NASEO) Buildings Committee, 1999. Energy efficiency in our schools: An update on states' energy-related schools programs (draft). September.

Natural Resources Canada. 2001. Energy Statistics Handbook. Statistics Canada. May.

Office of Management and Budget (OMB). 2001. "Guidelines and discount rates for benefitcost analysis of federal programs.” Circular no. A-94 revised. January.

Porter, Michael E. 1980. Competitive strategy. The Free Press, New York.

Public Benefits Technical Advisory Committee: Florida Energy 2020 Study Commission. 2001. Reliable, Sustainable, and Affordable: Maintaining Public Benefits in Florida's Electric System. 
Raftelis International Consulting Group. 1998. 1998 National Water and Wastewater Rate Survey: Exhibit I, North Carolina.

Raftelis International Consulting Group. 2000. 2000 National Water and Wastewater Rate Survey: Exhibit I, North Carolina.

U.S. Census Bureau. 2000. Census 2000 PHC-T-2: Table 1. States Ranked by Population http://www.census.gov/population/cen2000/phc-t2/tab01.pdf 


\section{Appendix A: Energy Conservation Measures from Survey}

\begin{tabular}{|c|c|c|c|c|c|}
\hline Measure & $\begin{array}{l}\text { Frequency } \\
(\mathrm{N}=1379)\end{array}$ & $\begin{array}{c}\text { Percent } \\
\text { of projects }\end{array}$ & Measure & $\begin{array}{l}\text { Frequency } \\
(\mathrm{N}=1379)\end{array}$ & $\begin{array}{c}\text { Percent } \\
\text { of projects }\end{array}$ \\
\hline COMFORT CONDITIONING & & & MFORT CONDITIONING -- CONT'D & & \\
\hline $\begin{array}{l}\text { HVAC general: } \\
\text { * HVAC - unspecified }\end{array}$ & 167 & $12 \%$ & $\begin{array}{l}\text { ventilation: } \\
\text { blowers }\end{array}$ & & \\
\hline furnaces/heaters & 32 & $2 \%$ & exhaust/fans & 69 & $5 \%$ \\
\hline heat recovery/storage & 48 & $3 \%$ & fume hoods & 4 & $0 \%$ \\
\hline spot/computer room AC & 4 & $0 \%$ & AQ/dehumidifiers: & & \\
\hline central plant/sources: & & & desiccants & 1 & $0 \%$ \\
\hline boilers & 310 & $22 \%$ & heat pipes & 0 & $0 \%$ \\
\hline chillers & 264 & $19 \%$ & controls & & \\
\hline cooling towers & 88 & $6 \%$ & * comfort conditioning controls & 116 & $8 \%$ \\
\hline unspecified packaged/roof-top systems: & & & energy management systems & 665 & $48 \%$ \\
\hline * packaged/roof-top systems - unspecified & 10 & $1 \%$ & thermostats & 65 & $5 \%$ \\
\hline * air compressors - AC/HP unspecified & 25 & $2 \%$ & building envelope & & \\
\hline * economisers - AC/HP unspecified & 39 & $3 \%$ & doors & 7 & $1 \%$ \\
\hline * heat exchangers $-\mathrm{AC} / \mathrm{HP}$ unspecified & 47 & $3 \%$ & insulation/weather proofing & 116 & $8 \%$ \\
\hline packaged/roof-top AC systems: & & & windows & 80 & $6 \%$ \\
\hline * packaged/roof-top AC systems & 5 & $0 \%$ & & & \\
\hline air-cooled compressors - AC & 11 & $1 \%$ & GHTING & & \\
\hline economisers (air side) - AC & 1 & $0 \%$ & * lighting retrofit - unspecified & 1080 & $78 \%$ \\
\hline economisers (water side) - AC & 1 & $0 \%$ & equipment: & & \\
\hline heat exchangers - AC & 2 & $0 \%$ & ballasts & 197 & $14 \%$ \\
\hline water-cooled compressors - AC & 2 & $0 \%$ & controls/motion sensors & 155 & $11 \%$ \\
\hline packaged/roof-top HP systems: & & & exit signs & 10 & $1 \%$ \\
\hline * packaged/roof-top HP systems & 28 & $2 \%$ & lamps & 211 & $15 \%$ \\
\hline air-cooled compressors - HP & 10 & $1 \%$ & parking lot/outdoor lighting & 4 & $0 \%$ \\
\hline economisers (air side) - HP & 2 & $0 \%$ & reflectors & 123 & $9 \%$ \\
\hline economisers (water side) - HP & 0 & $0 \%$ & other: & & \\
\hline heat exchangers - HP & 1 & $0 \%$ & daylighting & 1 & $0 \%$ \\
\hline water-cooled compressors - HP & 3 & $0 \%$ & & & \\
\hline distribution: & & & FRIGERATION & 0 & $0 \%$ \\
\hline air handling units & 231 & $17 \%$ & high efficiency refrigerators/freezers & 15 & $1 \%$ \\
\hline ducts/fittings & 8 & $1 \%$ & refrigeration plants & 11 & $1 \%$ \\
\hline piping/steam distribution & 96 & $7 \%$ & & & \\
\hline pumps \& priming systems & 92 & $7 \%$ & & & \\
\hline variable air volume & 26 & $2 \%$ & & & \\
\hline steam/heat traps & 105 & $8 \%$ & & & \\
\hline
\end{tabular}

* not included in most recent version of NAESCO accreditation form

NOTES:

1. Shaded headings indicate "Measure Categories" used for analysis purposes; italicized sub-headings are for display purposes only.

2. The sum of individual measure frequencies do not necessarily equal the frequencies of Measure Categories, as projects may list more than one measure within each category. For frequencies of measure categories, see Table 3.4.

3. Measures marked with an asterisk (*) are not included in the most recent NAESCO accreditation form, but are maintained in the database to track data collected in earlier versions. Similarly, measures with zero frequencies appear as choices on the form but to date have not been selected in the collected data. 


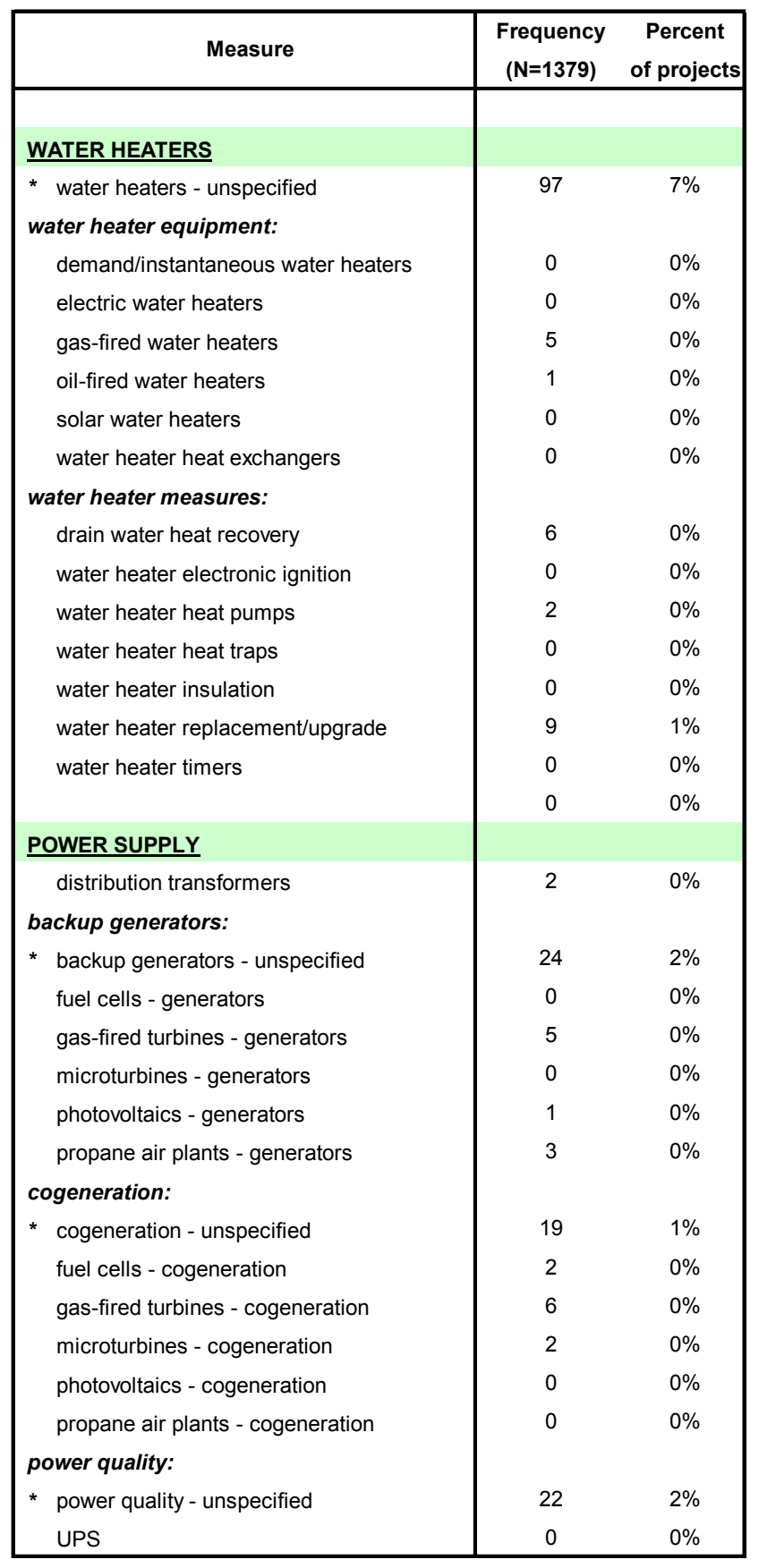

\begin{tabular}{|c|c|c|}
\hline Measure & $\begin{array}{l}\text { Frequency } \\
(\mathrm{N}=1379)\end{array}$ & $\begin{array}{c}\text { Percent } \\
\text { of projects }\end{array}$ \\
\hline \multicolumn{3}{|l|}{ MOTORS/DRIVES } \\
\hline engines & 4 & $0 \%$ \\
\hline variable speed drives & 231 & $17 \%$ \\
\hline \multicolumn{3}{|l|}{ electric motors: } \\
\hline * electric motors - unspecified & 135 & $10 \%$ \\
\hline motor resizing & 0 & $0 \%$ \\
\hline motor retrofit & 7 & $1 \%$ \\
\hline new/replacement motors & 21 & $2 \%$ \\
\hline \multicolumn{3}{|c|}{ MISCELLANEOUS EQUIPMENT/SYSTEMS } \\
\hline food warming elements & 6 & $0 \%$ \\
\hline office/computer equipment & 5 & $0 \%$ \\
\hline ovens & 14 & $1 \%$ \\
\hline pool systems & 12 & $1 \%$ \\
\hline traffic signals & 6 & $0 \%$ \\
\hline \multirow[t]{2}{*}{ vending machines } & 5 & $0 \%$ \\
\hline & 0 & $0 \%$ \\
\hline \multicolumn{3}{|l|}{ PLUMBING PRODUCTS \& FITTINGS } \\
\hline * water conservation - unspecified & 118 & $9 \%$ \\
\hline low-flow showers/faucets & 33 & $2 \%$ \\
\hline low-flow toilets/urinals & 17 & $1 \%$ \\
\hline spout diverters & 0 & $0 \%$ \\
\hline \multicolumn{3}{|c|}{ INDUSTRIAL PROCESS IMPROVEMENTS } \\
\hline * industrial processes - unspecified & 23 & $2 \%$ \\
\hline \multicolumn{3}{|l|}{ OTHER MEASURES/STRATEGIES } \\
\hline equipment scheduling controls & 1 & $0 \%$ \\
\hline fuel conversion & 123 & $9 \%$ \\
\hline load management systems & 16 & $1 \%$ \\
\hline metering/billing systems & 42 & $3 \%$ \\
\hline rate analysis/tariff change & 10 & $1 \%$ \\
\hline staff training & 157 & $11 \%$ \\
\hline \multicolumn{3}{|l|}{ NON-ENERGY IMPROVEMENTS } \\
\hline asbestos abatement & 12 & $1 \%$ \\
\hline ceilings & 6 & $0 \%$ \\
\hline fuel tanks & 2 & $0 \%$ \\
\hline roof replacement/repair & 27 & $2 \%$ \\
\hline
\end{tabular}

* not included in most recent version of NAESCO accreditation form

NOTES:

1. Shaded headings indicate "Measure Categories" used for analysis purposes; italicized sub-headings are for display purposes only.

2. The sum of individual measure frequencies do not necessarily equal the frequencies of Measure Categories, as projects may list more than one measure within each category. For frequencies of measure categories, see Table 3.4.

3. Measures marked with an asterisk $(*)$ are not included in the most recent NAESCO accreditation form, but are maintained in the database to track data collected in earlier versions. Similarly, measures with zero frequencies appear as choices on the form but to date have not been selected in the collected data. 


\section{Appendix B: Deployment of Energy-Efficiency Measures by Market Segment}

\begin{tabular}{|c|c|c|c|c|c|c|c|c|}
\hline \multirow[t]{2}{*}{ Measure Category } & \multicolumn{2}{|c|}{$\begin{array}{c}\mathrm{K}-12 \text { Schools } \\
(\mathrm{N}=416)\end{array}$} & \multicolumn{2}{|c|}{$\begin{array}{c}\text { State/local gov't } \\
\quad(N=181)\end{array}$} & \multicolumn{2}{|c|}{$\begin{array}{l}\text { Univ./ college } \\
\qquad(\mathrm{N}=125)\end{array}$} & \multicolumn{2}{|c|}{$\begin{array}{l}\text { Federal gov't } \\
\quad(\mathrm{N}=82)\end{array}$} \\
\hline & $\mathrm{N}$ & $\%$ & $\mathrm{~N}$ & $\%$ & $\mathrm{~N}$ & $\%$ & $\mathrm{~N}$ & $\%$ \\
\hline Lighting & 381 & $92 \%$ & 163 & $90 \%$ & 108 & $86 \%$ & 58 & $71 \%$ \\
\hline Comfort Conditioning & 380 & $91 \%$ & 109 & $60 \%$ & 99 & $79 \%$ & 51 & $62 \%$ \\
\hline Motors/drives & 79 & $19 \%$ & 56 & $31 \%$ & 45 & $36 \%$ & 26 & $32 \%$ \\
\hline Water Heaters & 53 & $13 \%$ & 9 & $5 \%$ & 15 & $12 \%$ & 9 & $11 \%$ \\
\hline Non-Energy Improvements & 39 & $9 \%$ & 4 & $2 \%$ & 1 & $1 \%$ & 0 & $0 \%$ \\
\hline Power Supply & 29 & $7 \%$ & 7 & $4 \%$ & 8 & $6 \%$ & 7 & $9 \%$ \\
\hline Refrigeration & 3 & $1 \%$ & 1 & $1 \%$ & 1 & $1 \%$ & 2 & $2 \%$ \\
\hline Miscellaneous Equipment/ Systems & 26 & $6 \%$ & 7 & $4 \%$ & 2 & $2 \%$ & 1 & $1 \%$ \\
\hline Industrial Process Improvements & 2 & $0 \%$ & 0 & $0 \%$ & 0 & $0 \%$ & 2 & $2 \%$ \\
\hline Other Measures/ Strategies & 109 & $26 \%$ & 40 & $22 \%$ & 32 & $26 \%$ & 18 & $22 \%$ \\
\hline Plumbing Products \& Fittings & 28 & $7 \%$ & 17 & $9 \%$ & 17 & $14 \%$ & 10 & $12 \%$ \\
\hline Average No. of Measure Categories & \multicolumn{2}{|c|}{2.3} & \multicolumn{2}{|c|}{1.9} & \multicolumn{2}{|c|}{2.1} & \multicolumn{2}{|c|}{2.0} \\
\hline
\end{tabular}

\begin{tabular}{|c|c|c|c|c|c|c|}
\hline \multirow[t]{2}{*}{ Measure Category } & \multicolumn{2}{|c|}{$\begin{array}{l}\text { Health/ hospital } \\
(N=165)\end{array}$} & \multicolumn{2}{|c|}{$\begin{array}{l}\text { Public Housing } \\
\qquad(\mathrm{N}=39)\end{array}$} & \multicolumn{2}{|c|}{$\begin{array}{l}\text { Private sector } \\
\quad(N=359)\end{array}$} \\
\hline & $\mathrm{N}$ & $\%$ & $\mathrm{~N}$ & $\%$ & $\mathrm{~N}$ & $\%$ \\
\hline Lighting & 127 & $77 \%$ & 22 & $56 \%$ & 264 & $74 \%$ \\
\hline Comfort Conditioning & 107 & $65 \%$ & 22 & $56 \%$ & 163 & $45 \%$ \\
\hline Motors/drives & 45 & $27 \%$ & 3 & $8 \%$ & 64 & $18 \%$ \\
\hline Water Heaters & 6 & $4 \%$ & 9 & $23 \%$ & 15 & $4 \%$ \\
\hline Non-Energy Improvements & 2 & $1 \%$ & 0 & $0 \%$ & 0 & $0 \%$ \\
\hline Power Supply & 10 & $6 \%$ & 2 & $5 \%$ & 18 & $5 \%$ \\
\hline Refrigeration & 1 & $1 \%$ & 7 & $18 \%$ & 11 & $3 \%$ \\
\hline Miscellaneous Equipment/ Systems & 1 & $1 \%$ & 0 & $0 \%$ & 4 & $1 \%$ \\
\hline Industrial Process Improvements & 4 & $2 \%$ & 0 & $0 \%$ & 15 & $4 \%$ \\
\hline Other Measures/ Strategies & 27 & $16 \%$ & 20 & $51 \%$ & 41 & $11 \%$ \\
\hline Plumbing Products \& Fittings & 17 & $10 \%$ & 30 & $77 \%$ & 13 & $4 \%$ \\
\hline Average No. of Measure Categories & & & & & & \\
\hline
\end{tabular}




\section{Appendix C: Economic Indicators}

In this appendix, we describe the economic indicators used in our analysis as well as the approach used to develop several key inputs to that analysis: economic lifetime of installed ECMs, discount rate, retail electricity, gas, fuel oil, coal and water prices at the time that the project was completed, and energy escalation rates.

\section{Economic Indicators}

Gross benefits are the discounted monetized value of expected direct economic benefits (i.e., energy and non-energy savings). Net benefits are calculated by subtracting discounted project costs from gross benefits $(\mathrm{OMB}, 2001) .{ }^{38}$ The benefit-cost $(\mathrm{B} / \mathrm{C})$ ratio is obtained by dividing gross benefits by costs.

$$
\begin{aligned}
& \text { Gross Benefits }=\Sigma B_{n} /(1+r)^{n} \text {, where: } \\
& \mathrm{B}_{\mathrm{n}}=\text { annual benefits in year } \mathrm{n} \\
& r=\text { discount rate }
\end{aligned}
$$

(2) $\quad$ Net Benefits $=\left(\Sigma B_{n} /(1+r)^{n}\right)-C$, where:

$$
\mathrm{C}=\text { initial project costs. }
$$

These economic indicators are calculated in nominal dollars. ${ }^{39}$ To compare direct economic benefits among projects completed in different years we relied on the $\mathrm{B} / \mathrm{C}$ ratio.

\section{Simple Payback Time}

The simple payback time (SPT) is the time, in years, that savings must be realized before they will offset the investment costs of the project. It is a relatively easy way to estimate the time required to recover costs. However it fails to factor in the time value of money, inflation, or project lifetime.

We calculate SPT considering both energy and non-energy savings, ${ }^{40}$ described as:

$$
\mathrm{SPT}=\text { project costs/(dollar value of energy }+ \text { O\&M + other savings })
$$

\footnotetext{
38 Project costs are assumed to be paid up-front in year one at time of customer acceptance; ESCOs did not report on-going project service costs, such as maintenance and measurement/verification costs, so there were no annual recurring project costs to discount.

${ }^{39}$ To compare projects completed in different years, ideally the analysis would be done in constant dollars. However, we made the simplifying assumption that project economics should be evaluated from the customer's perspective at the time they were completed. Use of B/C ratio and SPT (rather than net benefits) does not introduce a systematic bias in comparing among projects.

${ }^{40}$ As already stated, these savings do not include any valuation of increased amenity or productivity or other indirect benefits that may have resulted from the projects.
} 
The dollar value of energy savings was determined by multiplying the average annual energy savings by the appropriate unit price for that energy in the year the project was completed. Our sources of fuel price data are explained in this Appendix. By matching fuel prices with the year of project completion, we ensure that project costs and savings are in a consistent year's dollars. If actual energy savings were not available, we used the dollar value of savings as reported by the ESCO.

\section{Energy and Non-Energy Savings}

ESCOs reported both energy and non-energy savings for each project. Energy savings are the yearly or average annual energy and other resources saved as a result of installing conservation measures. ${ }^{41}$ These savings estimates reflect any baseline adjustments made by the ESCO that are part of the contractual agreement. They may be reported as electricity, other fuels (specified as natural gas, oil or coal), water, and/or dollars. Non-energy savings include only O\&M savings and any other monetary savings directly attributable to the project, such as a tariff change that results from fuel switching of equipment

\section{$\underline{\text { Economic Lifetime }}$}

We assumed that the energy and non-energy benefits of each project would be sustained over the economic lifetime of installed measures. For each project in which multiple measures were installed, the economic lifetime of the longest-lived measure was chosen because we assumed the majority of the project's savings were attributable to that measure. Savings decay rates (i.e., savings that decrease as the ECM ages and experiences a reduction in performance) are incorporated into the measure's assumed economic lifetime. Our assumptions for economic lifetime were based primarily on the California Energy Commission's Database on EnergyEfficiency Resources (CEC, 1995). The economic lifetimes used for each ECM are:

$\begin{array}{lc}\text { Energy Conservation Measure } & \text { Economic Lifetime (years) } \\ \text { - HVAC equipment } & 18 \\ \text { - HVAC controls } & 10 \\ \text { - Building envelope } & 25 \\ \text { - Lighting } & 10 \\ \text { - Refrigeration } & 18 \\ \text { - Water heaters } & 13 \\ \text { - Power supply } & 20 \\ \text { - Motor/drives } & 16 \\ \text { - Miscellaneous equipment } & 15 \\ \text { - Plumbing products } & 7 \\ \text { - Industrial processes } & 20\end{array}$

${ }^{41}$ If actual savings were not reported, predicted savings were substituted. 


\section{$\underline{\text { Discount Rate }}$}

We selected nominal discount rates of $7 \%$ and $10 \%$ for institutional sector projects and $10 \%$ and $15 \%$ for private sector projects. We used these discount rates to determine the net present value of the annual stream of economic benefits and costs for ESCO projects (in nominal dollars).

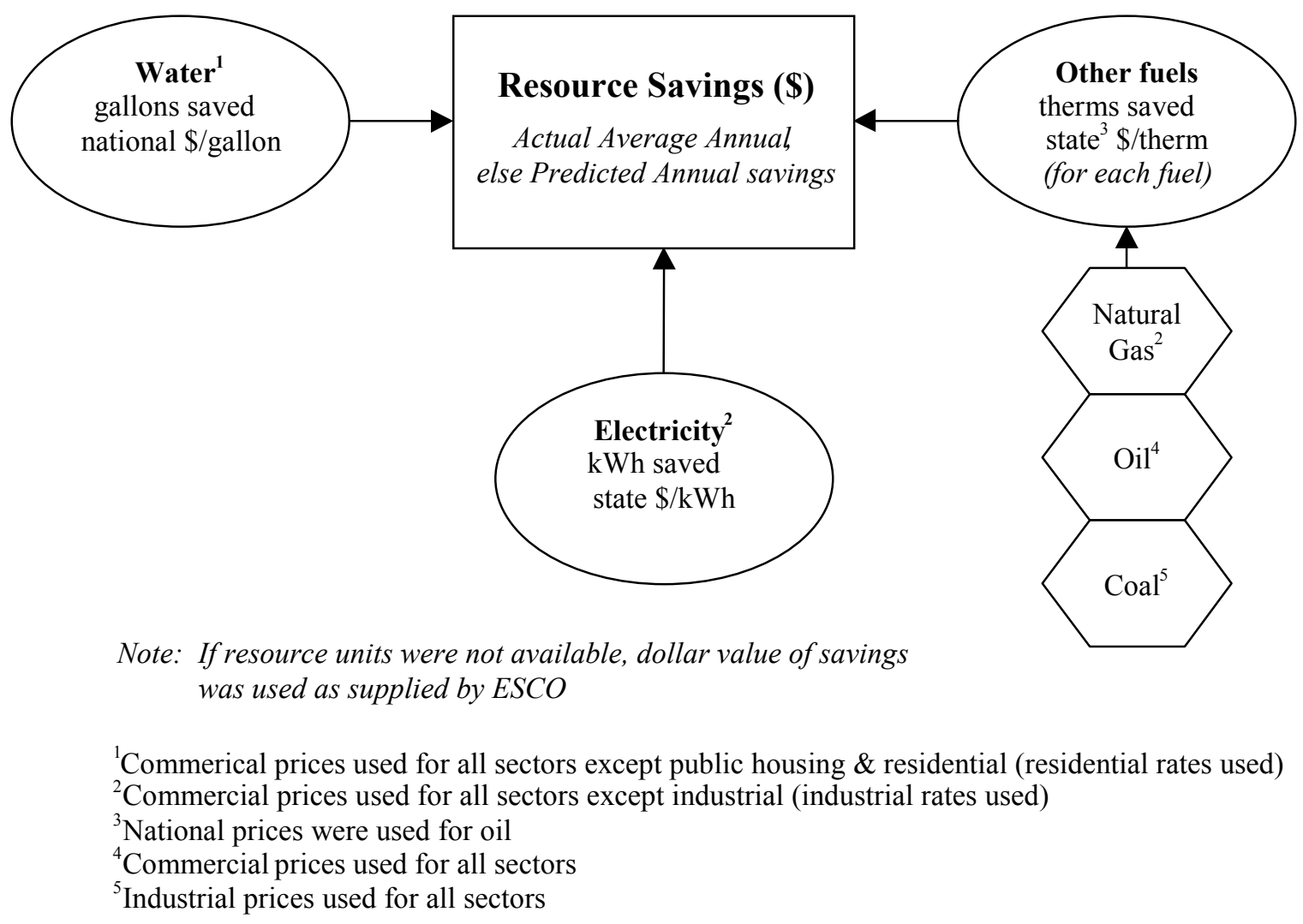

Figure C- 1. Collection and Aggregation of Project Consumption and Savings Data

\section{Resource Prices (fuel and water)}

For each project, ESCOs were asked to provide either the yearly or average annual energy and water savings in units appropriate for the given fuel(s)/resource, or the yearly or average annual dollar value of energy and water savings. In some cases, both energy/resource units and dollar values were provided. If resource units were given, we calculated the dollar value of the average annual savings using fuel and water prices indexed to the year the project was completed (cited below, and shown in Figure C-1). We matched resource prices geographically, temporally (based on the year of project completion), by sector (residential, commercial, and industrial), and by fuel/resource type for each project. All domestic energy prices were gathered from the U.S. Department of Energy's Energy Information Administration (EIA). Commercial electricity and natural gas prices were used for all sectors except industrial. Canadian energy prices were from Natural Resources Canada's Energy Statistics Handbook. Several different sources were used for water prices to cover the time periods over which projects in the database were completed. Commercial water prices were used for all sectors except for public housing and residential, for which residential prices were used. 
Specific sources for energy price data in each year are as follows:

Energy Prices (1982-2001)

Geographic

\begin{tabular}{|c|c|c|c|}
\hline Type & Specificity & Year & Source \\
\hline Coal & State & $\begin{array}{l}1990, \\
1995-9\end{array}$ & Coal Industry Annual 1999: Table 94 \\
\hline \multirow[t]{8}{*}{ Electricity } & State & $\begin{array}{l}2000 \\
1993-9\end{array}$ & $\begin{array}{l}\text { Electric Power Monthly, March 2001: Table 55 } \\
\text { Electric Power Annual, Volume II, 1994, 1996, 1998, and } \\
\text { 1999: Table } 7\end{array}$ \\
\hline & & $1990-2$ & Electric Power Annual 1991 and 1993, Table 29 \\
\hline & & 1989 & Electric Power Annual 1990, Table 30 \\
\hline & & $1987-8$ & Electric Power Annual 1988, Table 22 \\
\hline & & $1985-6$ & Typical Electric Bills: Table A1 \\
\hline & Canada & $1982-$ & Energy Statistics Handbook, Tables 10.38 (commercial) \\
\hline & & 1994 & and 10.40 (industrial) \\
\hline & & $1995-$ & Natural Resources Canada \\
\hline
\end{tabular}

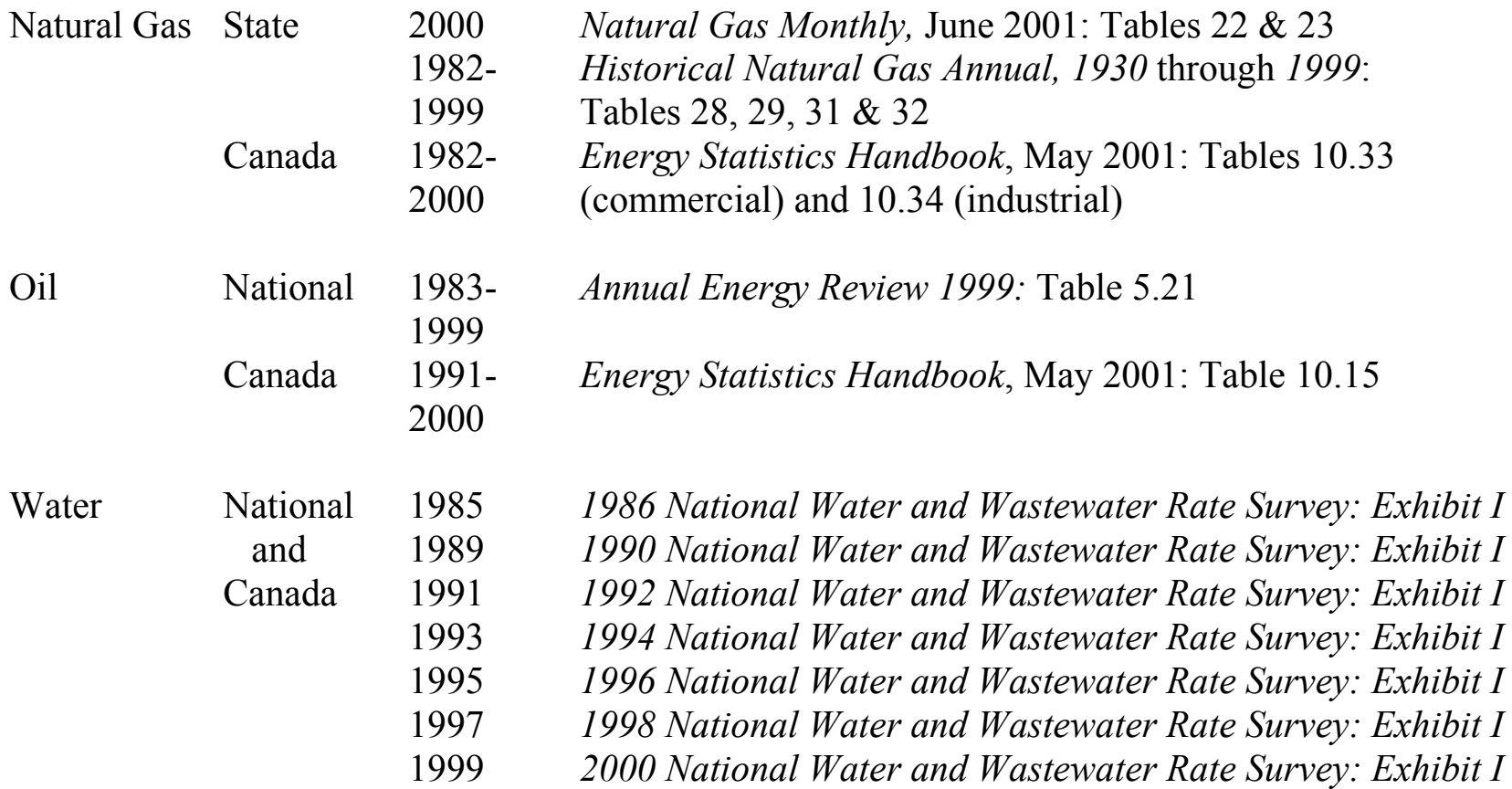

We accounted for future projections of retail energy prices over the project's economic lifetime by using EIA projected energy escalation rates published in EIA's Annual Energy Outlook. Specific sources for these energy escalation rates are listed below. 
Energy Escalation Rates (1982-2001)

$\begin{array}{lll}\begin{array}{l}\text { Type } \\ \text { All }\end{array} & \begin{array}{l}\text { Year } \\ 1982\end{array} & \begin{array}{l}\text { Source } \\ \text { Energy Information Administration, 1981 Annual Report to } \\ \text { Congress vol. 3: Table 3.2 }\end{array} \\ \text { Coal } & 1983-2001 & \begin{array}{l}\text { Energy Information Administration, Annual Energy Outlook: } \\ \text { Table A16 (or equivalent) }\end{array} \\ \text { Electricity } & 1983-2001 & \begin{array}{l}\text { Energy Information Administration, Annual Energy Outlook: } \\ \text { Table A8 (or equivalent) } \\ \text { Energy Information Administration, Annual Energy Outlook: } \\ \text { Nable A14 (or equivalent) }\end{array} \\ \text { Oil } & 1983-2001 \text { Gas } & \begin{array}{l}\text { Table } \\ \text { Energy Information Administration, Annual Energy Outlook: } \\ \text { Table A12 (or equivalent) }\end{array}\end{array}$

Energy escalation rates used by EIA are expressed in real terms. We converted these to nominal dollars using the Office of Management and Budget's Nominal Treasury Interest Rates. These same rates were used for both the U.S. and Canada. Appendix D lists the actual fuel prices and escalation rates used in the economic analysis.

The ESCO's estimated annual dollar value of savings was used in cases where ESCOs did not provide energy savings. For 609 projects, ESCOs reported both the energy and dollar value of savings. For this sub-set of projects, we compared the ESCO's estimates of dollar savings with our estimates, which were derived from energy savings, electricity \& fuel prices, and our assumed energy escalation rates. Over this sample of projects, the percent difference between ESCO projections and our estimates varies widely, with the median being $4 \%$. 


\section{Appendix D: Fuel Prices and Escalation Rates Used to Calculate Net Benefits}

The following data tables are available for download at:

http://eetd.lbl.gov/ea/EMS/EMS_pubs.html

Table D-1. Commercial Electricity Prices (cents/kWh) by year and state/province

Table D-2. Industrial Electricity Prices (cents/kWh) by year and state/province

Table D-3. Commercial Natural Gas Prices (\$/therm) by year and state/province

Table D-4. Industrial Natural Gas Prices ( $\$ /$ therm) by year and state/province

Table D-5. Industrial Coal Prices (\$/short ton) by year and state

Table D-6. Commercial Oil Prices (\$/therm) by year and country

Table D-7. Water Prices (cents/gallon) by year, country and sector

Table D-8. Forecasted fuel price escalation rates (\%) by year, fuel \& sector 


\section{Appendix E: Companies Surveyed for Aggregate Industry Activity}

\author{
1 1st Rochdale Cooperative Group \\ 2 Abacus Engineered Systems, Inc. \\ 3 Alliant \\ 4 Ameresco \\ 5 Building Controls \& Services \\ 6 Carrier Corporation \\ 7 Castro Technical \\ 8 Chevron Energy Solutions LP \\ 9 Co-Energy \\ 10 Combined \\ 11 Con Edison Solutions \\ 12 Custom Energy \\ 13 DukeSolutions, Inc. \\ 14 EES, Inc. \\ 15 EMCOR \\ 16 Energy @ Work, Inc. \\ 17 Energy Assets \\ 18 Energy Conservation \& Supply \\ 19 Energy Control Inc. (ECl) \\ 20 Energy Masters \\ 21 Energy Services Group, LLC \\ 22 Energy Systems Group \\ 23 Energysolve.com \\ 24 EnerShop \\ 25 Engineering Economics, Inc \\ 26 Ennovate Corporation \\ 27 Enron Energy Services \\ 28 EnSave Energy Performance, Inc. \\ 29 EnviroActive \\ 30 EPS Capital Corp. \\ 31 Essco Inc.
}

32 Evantage

33 Exelon Solutions

34 First Energy Services

35 FPL Energy Services

36 Honeywell

37 Invensys

38 Johnson Controls

39 Kenetech

40 LGE Enertech

41 McKinstry Company

42 Niagara Mohawk Energy Inc.

43 Noresco

44 Onsite Energy

45 Perfection Services

46 PSEG

47 Reliant

48 Select Energy Services/HEC

49 Sempra

50 Siemens

51 SLI

52 Southern Co Energy Solutions

53 SRS

54 TAC Americas

55 TECO Solutions

56 Texas Utilities Energy Services

57 The Trane Company

58 Trigen Energy Corporation

59 Ucons, LLC

60 Vermont Energy Investment Corp

61 Vestar

62 Viron

63 Water \& Energy Savings Corp 